Portland State University

PDXScholar

\title{
Applying an Equity Lens to Automated Payment Solutions for Public Transportation
}

\author{
Aaron Golub \\ Portland State University, agolub@pdx.edu \\ John MacArthur \\ Portland State University, macarthur@pdx.edu \\ Anne Brown \\ University of Oregon \\ Candace Brakewood \\ University of Tennessee - Knoxville
}

Follow this and additional works at: https://pdxscholar.library.pdx.edu/trec_reports

Part of the Transportation Commons, Urban Studies Commons, and the Urban Studies and Planning Commons

Let us know how access to this document benefits you.

\section{Recommended Citation}

Golub, A., J. MacArthur, C. Brakewood and A. Brown. Applying an Equity Lens to Automated Payment Solutions for Public Transportation. NITC-RR-1268. Portland, OR: Transportation Research and Education Center (TREC), 2021. https://dx.doi.org/10.15760/trec.261

This Report is brought to you for free and open access. It has been accepted for inclusion in TREC Final Reports by an authorized administrator of PDXScholar. Please contact us if we can make this document more accessible: pdxscholar@pdx.edu. 

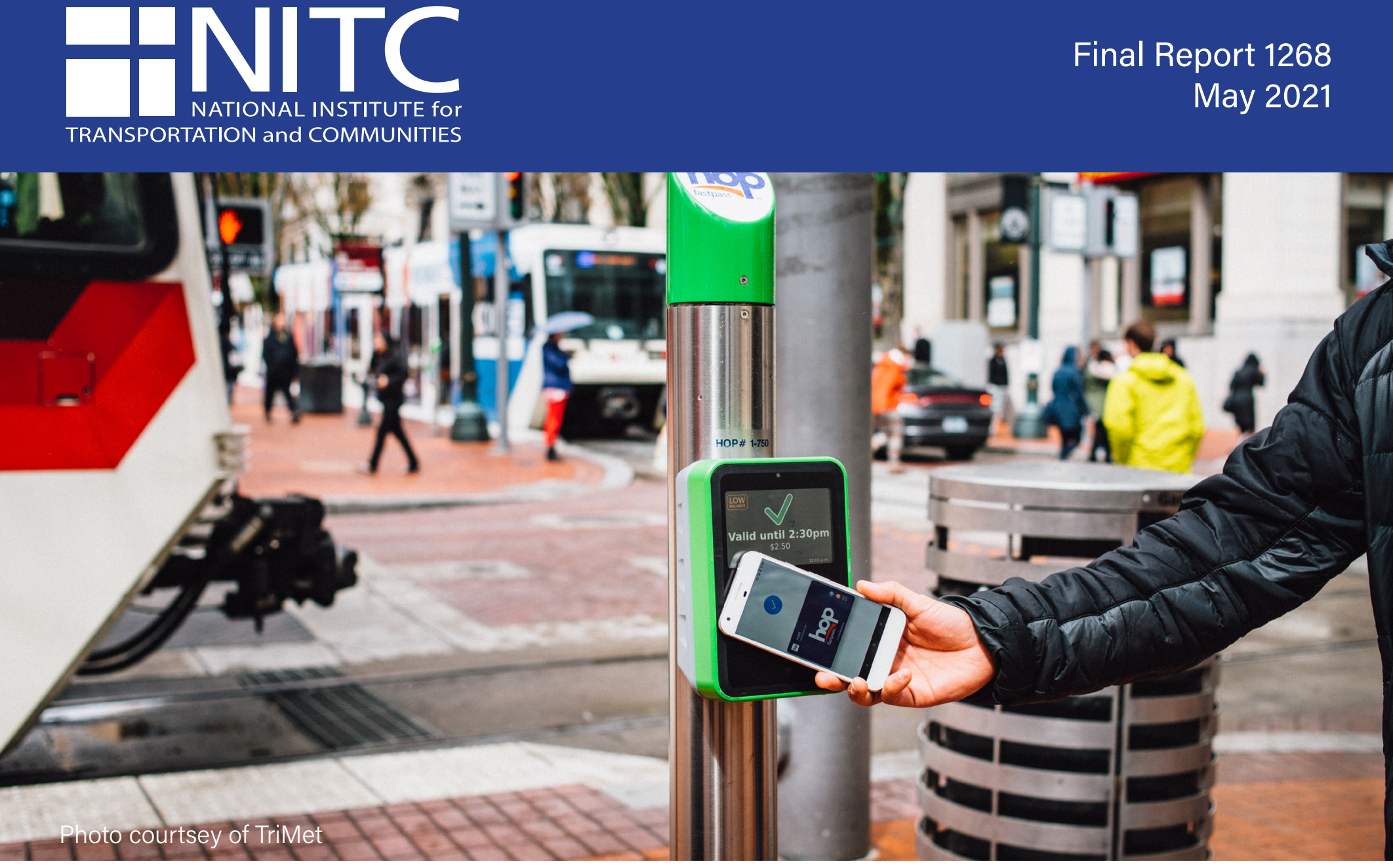

\section{Applying an Equity Lens to Automated Payment Solutions for Public Transportation}

Aaron Golub, Ph.D.

Anne Brown, Ph.D.

Candace Brakewood, Ph.D.

John MacArthur

TENIVESITEE

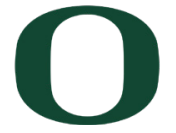

UNIVERSITY OF

舟

Portland State 


\title{
APPLYING AN EQUITY LENS TO AUTOMATED PAYMENT SOLUTIONS FOR PUBLIC TRANSPORTATION
}

\section{Final Report}

\author{
NITC-RR-1268 \\ Aaron Golub \\ John MacArthur \\ Portland State University \\ Anne Brown \\ University of Oregon \\ Candace Brakewood \\ University of Tennessee - Knoxville
}

for

National Institute for Transportation and Communities (NITC)

P.O. Box 751

Portland, OR 97207
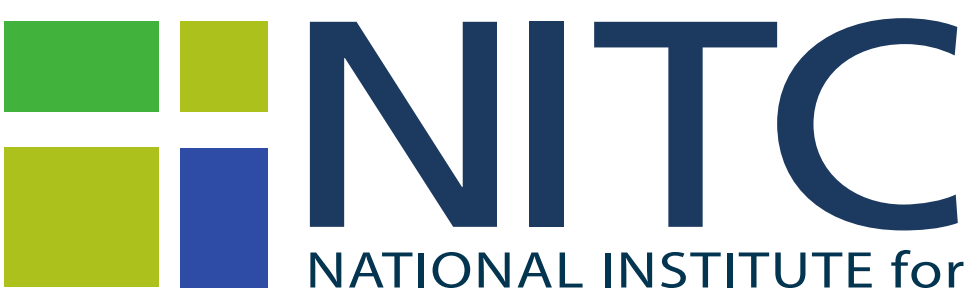

NATIONAL INSTITUTE for

TRANSPORTATION and COMMUNITIES

May 2021 


\begin{tabular}{|c|c|c|c|c|}
\hline $\begin{array}{l}\text { Technical Report Docume } \\
\text { 1. Report No. } \\
\text { NITC-RR-1268 }\end{array}$ & \multicolumn{2}{|l|}{ 2. Government Accession No. } & \multicolumn{2}{|c|}{ 3. Recipient's Catalog No. } \\
\hline \multirow{2}{*}{\multicolumn{3}{|c|}{$\begin{array}{l}\text { 4. Title and Subtitle } \\
\text { Applying an Equity Lens to Automated Payment Solutions for Public Transportation }\end{array}$}} & \multicolumn{2}{|c|}{$\begin{array}{l}\text { 5. Report Date } \\
\text { May } 2021\end{array}$} \\
\hline & & & \multicolumn{2}{|c|}{ 6. Performing Organization Code } \\
\hline \multicolumn{3}{|c|}{$\begin{array}{l}\text { 7. Authors } \\
\text { Aaron Golub: 0000-0002-5999-0593 } \\
\text { Anne Brown: 0000-0001-5009-8331 } \\
\text { Candace Brakewood: 0000-0003-2769-7808 } \\
\text { John MacArthur: 0000-0002-3462-1409 }\end{array}$} & \multicolumn{2}{|c|}{$\begin{array}{l}\text { 8. Performing Organization Report } \\
\text { No. }\end{array}$} \\
\hline \multirow{2}{*}{\multicolumn{3}{|c|}{$\begin{array}{l}\text { 9. Performing Organization Name and Address } \\
\text { Portland State University, University of Oregon and University of Tennessee - Knoxville }\end{array}$}} & \multicolumn{2}{|c|}{ 10. Work Unit No. (TRAIS) } \\
\hline & & & \multicolumn{2}{|c|}{$\begin{array}{l}\text { 11. Contract or Grant No. } \\
\text { NITC-RR-1268 }\end{array}$} \\
\hline \multirow{2}{*}{\multicolumn{3}{|c|}{$\begin{array}{l}\text { 12. Sponsoring Agency Name and Address } \\
\text { Funds pooled from : City of Eugene, OR, City of Gresham, OR, Lane Transit District, } \\
\text { Clevor Consulting Group, RTD Denver and National Institute for Transportation and } \\
\text { Communities (NITC), P.O. Box 751, Portland, Oregon } 97207\end{array}$}} & \multicolumn{2}{|c|}{$\begin{array}{l}\text { 13. Type of Report and Period } \\
\text { Covered }\end{array}$} \\
\hline & & & \multicolumn{2}{|c|}{ 14. Sponsoring Agency Code } \\
\hline \multicolumn{5}{|l|}{ 15. Supplementary Notes } \\
\hline \multicolumn{5}{|c|}{ 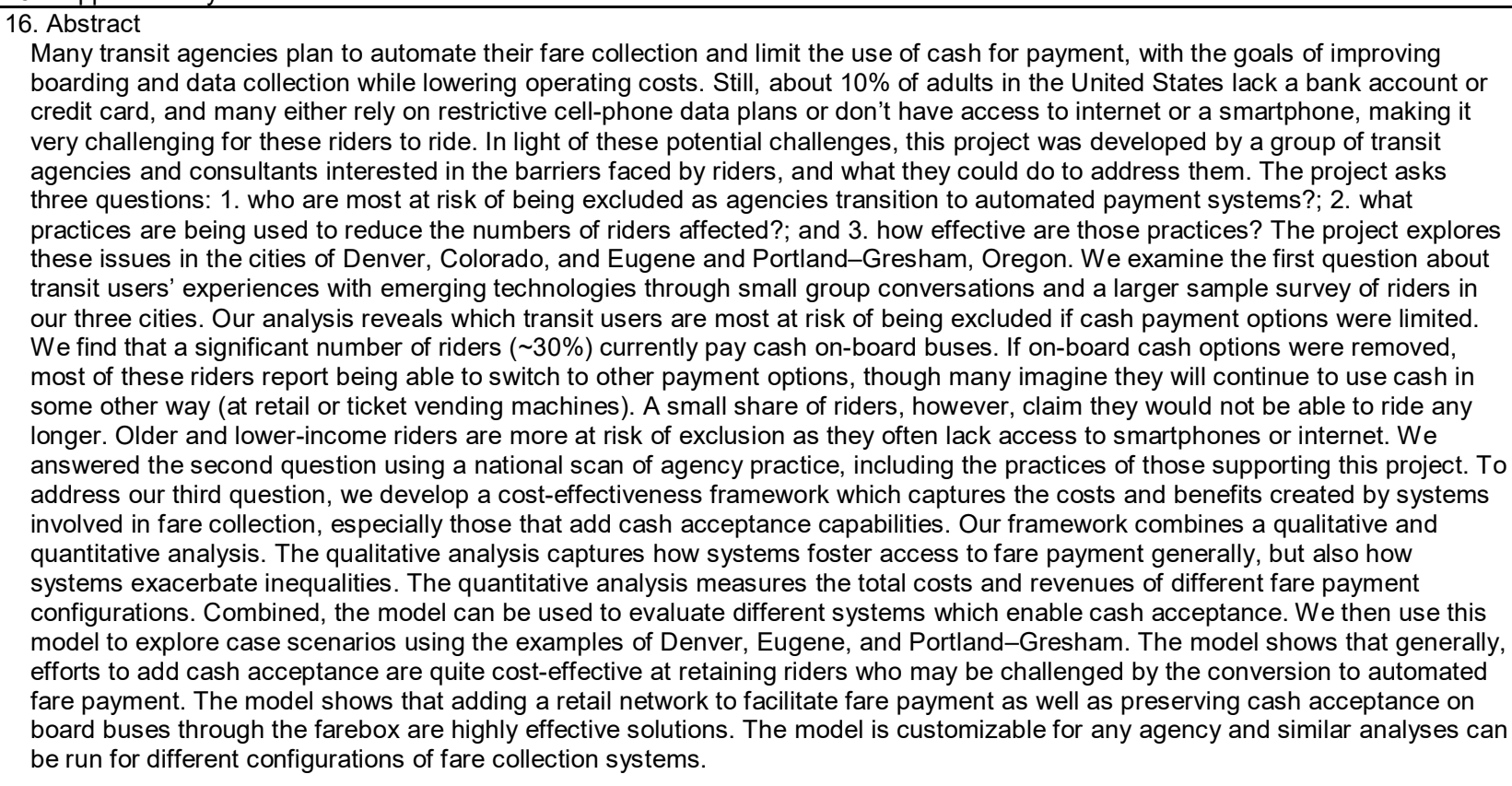 } \\
\hline \multicolumn{2}{|c|}{$\begin{array}{l}\text { 17. Key Words } \\
\text { Transit, fare policy, equity, collection, automation }\end{array}$} & \multicolumn{3}{|c|}{$\begin{array}{l}\text { 18. Distribution Statement } \\
\text { No restrictions. Copies available } \\
\text { www.nitc-utc.net }\end{array}$} \\
\hline $\begin{array}{l}\text { 19. Security Classification (of this report) } \\
\text { Unclassified }\end{array}$ & $\begin{array}{l}\text { 20. Security Classification (of thi } \\
\text { page) } \\
\text { Unclassified }\end{array}$ & & of Pages & 22. Price \\
\hline
\end{tabular}




\section{ACKNOWLEDGEMENTS}

This project was supported by a Pooled Fund grant from the National Institute for

Transportation and Communities (NITC-RR-1268), a U.S. DOT University

Transportation Center; and by the City of Eugene, OR, City of Gresham, OR, Lane Transit District, Clevor Consulting Group, and RTD Denver.

\section{DISCLAIMER}

The contents of this report reflect the views of the authors, who are solely responsible for the facts and the accuracy of the material and information presented herein. This document is disseminated under the sponsorship of the U.S. Department of Transportation University Transportation Centers Program [and other SPONSOR/PARTNER] in the interest of information exchange. The U.S. Government [and other SPONSOR/PARTNER] assumes no liability for the contents or use thereof. The contents do not necessarily reflect the official views of the U.S. Government [and other SPONSOR/PARTNER]. This report does not constitute a standard, specification, or regulation.

\section{RECOMMENDED CITATION}

Golub, A., J. MacArthur, C. Brakewood and A. Brown. Applying an Equity Lens to Automated Payment Solutions for Public Transportation. NITC-RR-1268. Portland, OR: Transportation Research and Education Center (TREC), 2021. 


\section{Table of Contents}

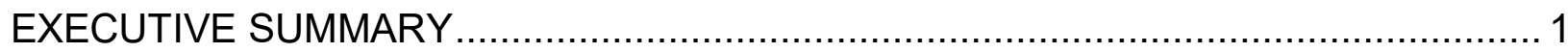

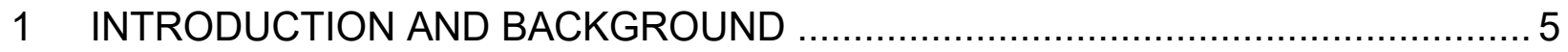

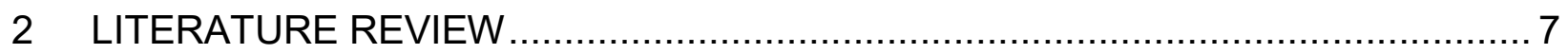

2.1 Trends in Transit Fare Payment Technology ............................................. 7

2.2 OBSTACLES TO CASHLESS FARE PAYMENTS …................................. 10

2.2.1 Underbanked and Unbanked Riders ................................................ 10

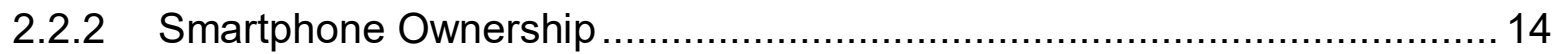

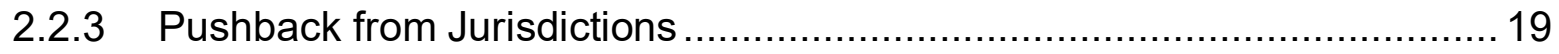

2.3 TRANSIT AGENCY EXAMPLES THAT ADDRESS EQUITY .........................20

2.4 MULTI-MODAL CONNECTIONS TO TRANSIT ............................................. 21

2.4.1 Taxis and Transportation Network Companies (TNCs) ........................... 21

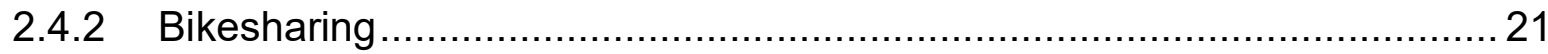

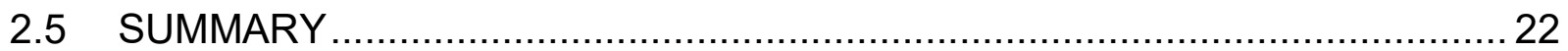

3 ANALYSIS OF PAYMENT BEHAVIOR AND POTENTIAL FOR EXCLUSION ......23

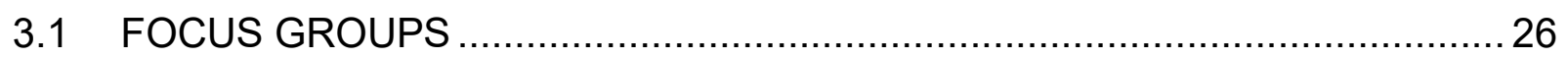

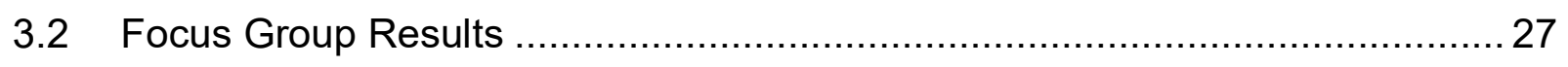

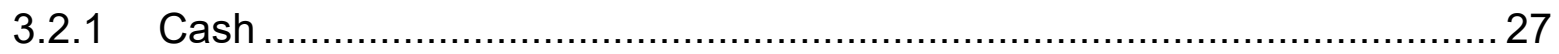

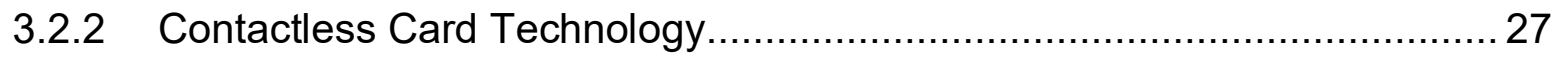

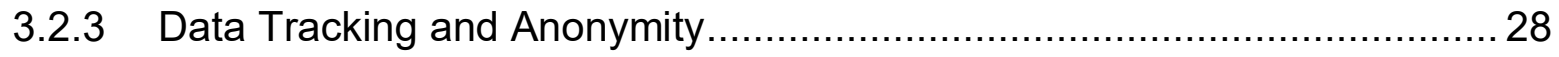

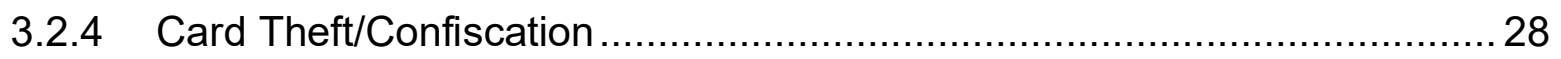

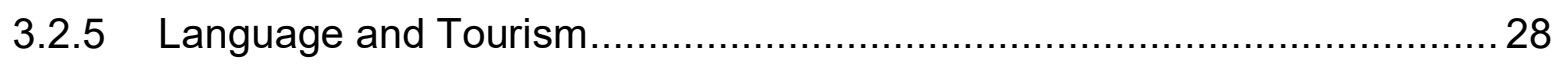

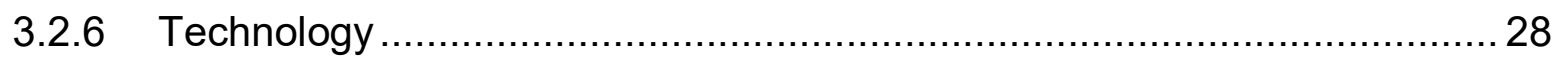

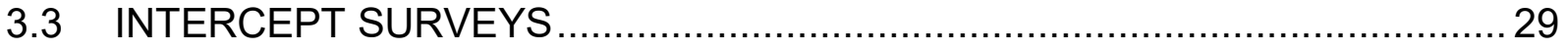

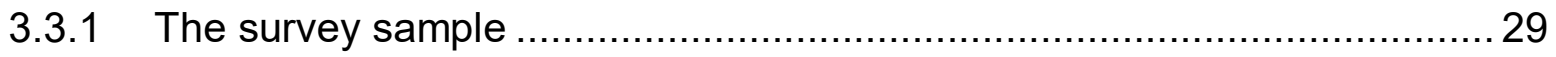

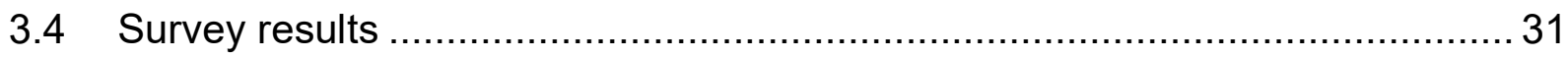

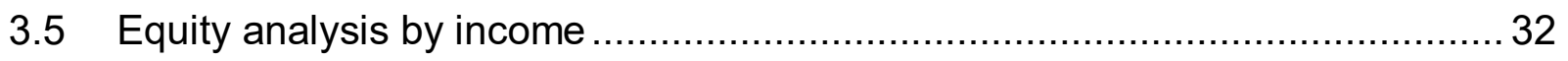

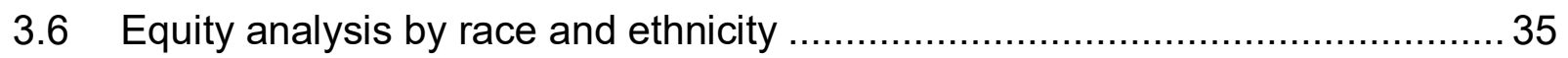

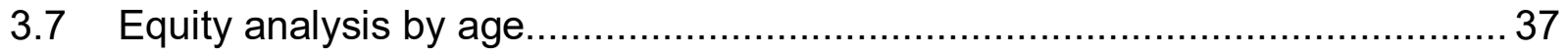

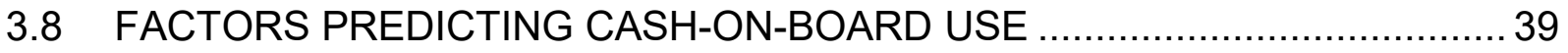

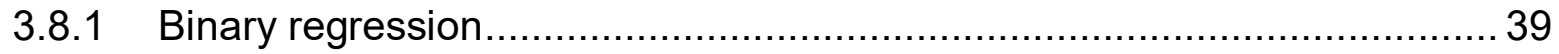

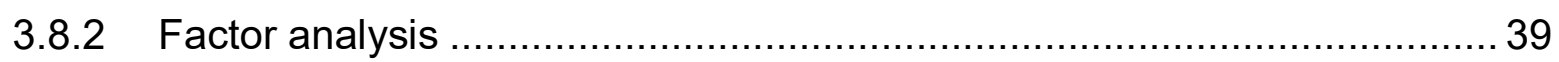




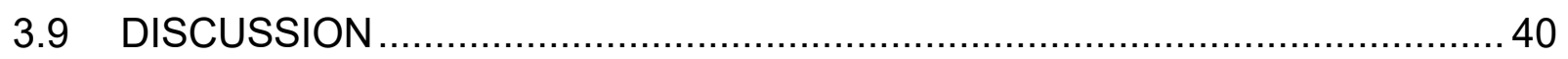

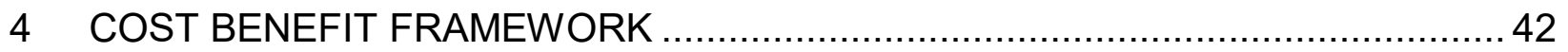

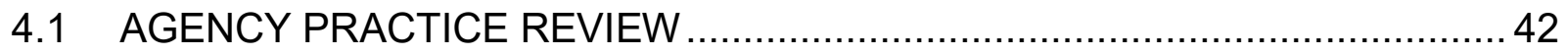

4.2 COST EFFECTIVENESS FRAMEWORK …............................................ 43

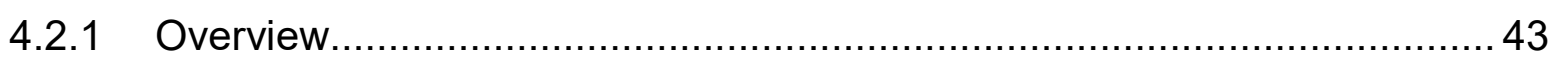

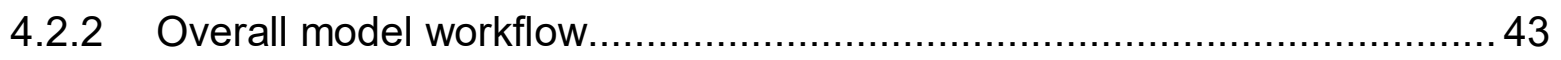

4.3 Quantitative Cost and Revenue Analysis ................................................ 44

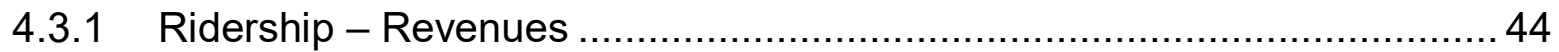

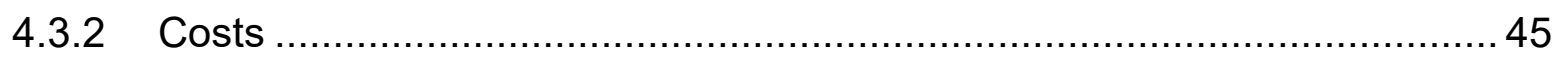

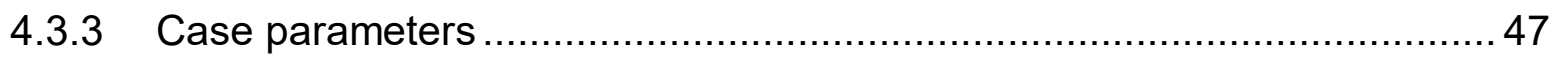

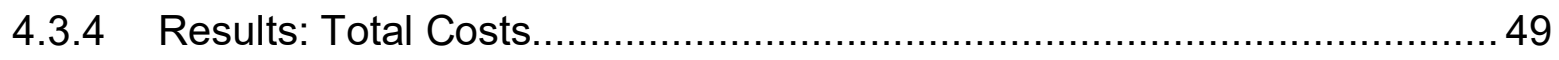

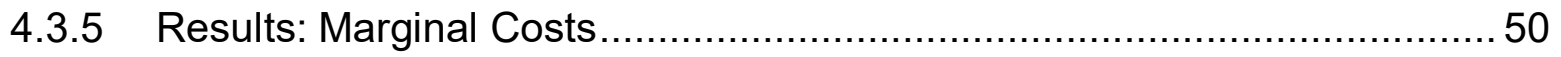

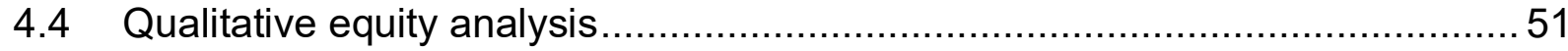

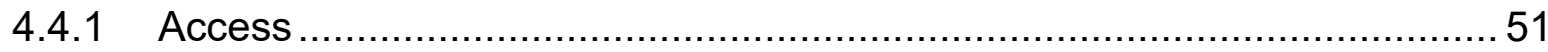

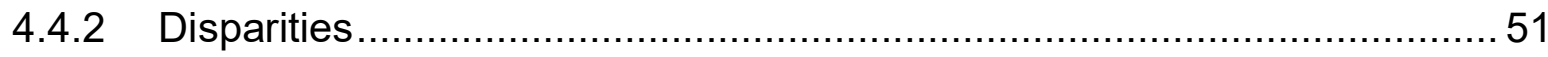

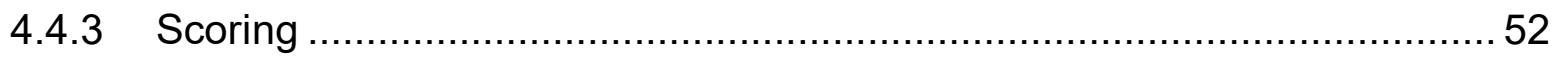

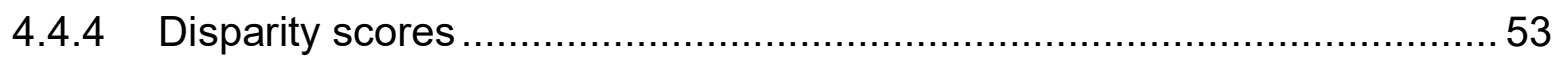

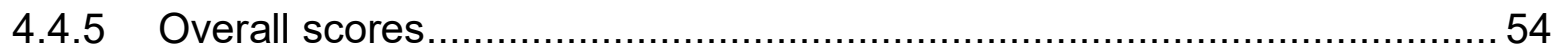

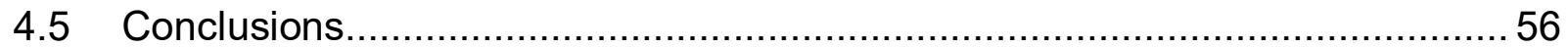

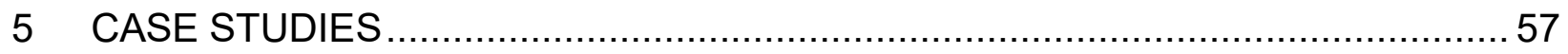

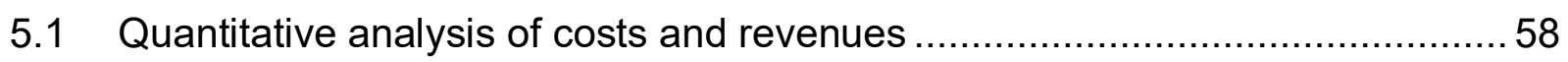

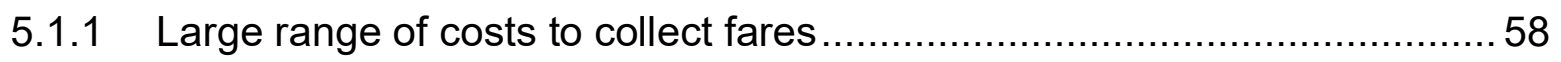

5.1.2 Different Scenarios maximize net revenues ...................................... 58

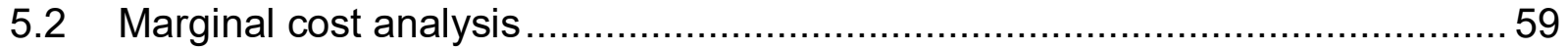

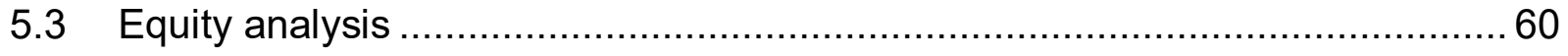

6 LESSONS FOR TRANSITIONS TO CASH-LIMITED FARE PAYMENT WITH

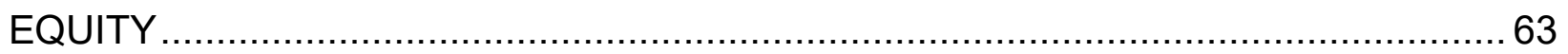

6.1 Larger properties spend less to collect fare.............................................. 63

6.2 Simple cash collection on buses could be an important bridge ...................... 63

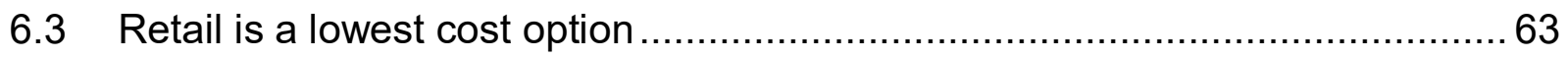

6.4 When larger numbers of riders are excluded, equity mitigations are cheaper.. 64

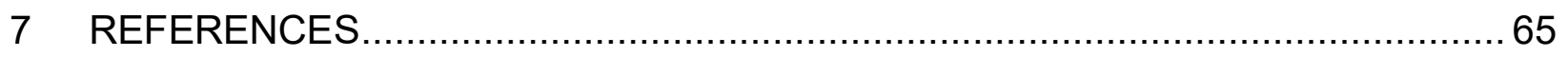

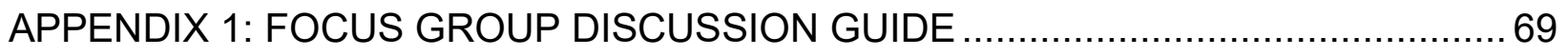




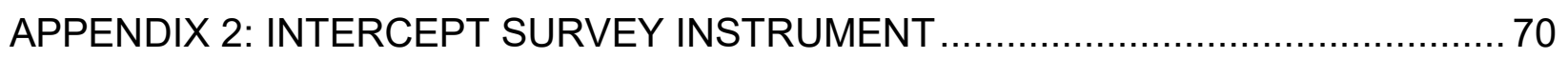

APPENDIX 3: AGENCY PRACTICE SCAN CONTACT LIST ................................... 75

APPENDIX 4: RESPONSES TO AGENCY PRACTICE SURVEY ............................ 79

\section{LIST OF TABLES}

Table 2.1: 2017 Nationwide Household Banking Status by Household Characteristics 13 Table 2.2: CTA banked and unbanked rider statistics ................................................ 14

Table 2.3: Percent of Adults in the United States Who Own the Following Devices...... 17

Table 2.4: Smartphone ownership from the NICE Bus system-wide survey ................. 18

Table 2.5: Percentage of bus riders with access to smartphones in Saint Louis........... 19

Table 3.1: Basic operating dimensions of case study regions .................................... 23

Table 3.2: Demographic Breakdown of Survey Sample ............................................. 30

Table 3.3: Overall breakdown of survey results ..................................................... 32

Table 3.4: Breakdown of survey results by income .................................................. 34

Table 3.5: Breakdown of survey results by race/ethnicity........................................ 36

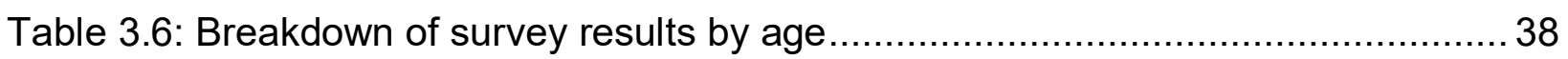

Table 3.7: Binary regression to predict current payment using cash-on-board .............. 39

Table 3.8: Component Score Coefficient Matrix...................................................... 40

Table 4.1: Unit Costs (Portland-Gresham example) ................................................. 46

Table 4.2: Case parameters (Portland-Gresham example) ...................................... 47

Table 4.3: Scenario descriptions (Portland-Gresham example) …........................... 47

Table 4.4: Scenario Ridership and Cash share of revenue (Portland-Gresham example)

Table 4.5: Scenario ridership calculations (Portland-Gresham example) ..................... 49

Table 4.6: Total Costs - Portland-Gresham example ............................................. 50

Table 4.7: Marginal Costs - Portland-Gresham example........................................... 51

Table 4.8: Qualitative analysis scoring (Portland-Gresham example) ..........................53

Table 4.9: Survey question results relating to comfort using automated fare technologies

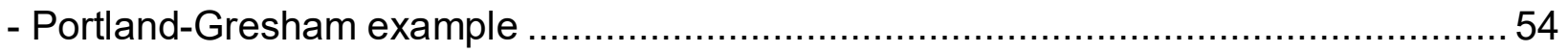

Table 4.10: Overall qualitative analysis averages - Portland-Gresham example $(-2=$ very problematic, $0=$ neutral $/$ not applicable/no problem $/$ no disparity). 55 
Table 4.11: Marginal changes (difference from the base case) in qualitative analysis averages - Portland-Gresham example $(-2=$ very problematic, $0=$ neutral $/$ not

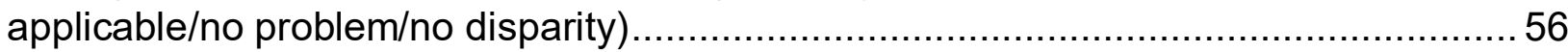

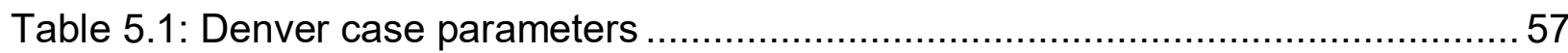

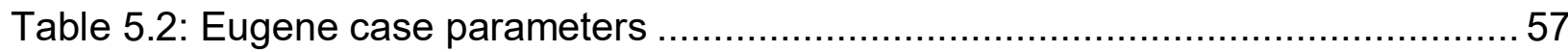

Table 5.3: Portland-Gresham case parameters ……........................................... 58

Table 5.4: Comparison of costs and revenues for the three agencies ........................59

Table 5.5: Comparison of marginal costs and revenues for the three agencies............6 60

Table 5.6: Qualitative equity analysis for the three agencies .................................. 61

Table 5.7: Marginal change in qualitative equity analysis for the three agencies ..........62

\section{LIST OF FIGURES}

Figure 2.1: Denver RTD mobile fare payment application....................................... 8

Figure 2.2 NFC Payment technology for transit fares............................................ 9

Figure 2.3: Percent of unbanked households over time ......................................... 11

Figure 2.4: Banked, underbanked, and unbanked statistics.................................. 12

Figure 2.5: Percent of adults in the United States who own a smartphone .................. 15

Figure 2.6: Smartphone ownership for the United States and transit riders ................. 15

Figure 2.7: Timeline of laws against cashless stores ................................................ 19

Figure 3.1: Map of Portland-Gresham transit coverage ............................................... 24

Figure 3.2: Map of Eugene, Oregon transit coverage............................................... 25

Figure 3.3: Map of Denver, Colorado transit coverage ............................................ 26

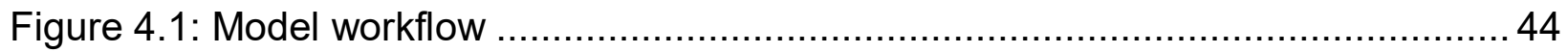




\section{EXECUTIVE SUMMARY}

Transit agencies are increasingly adopting cashless fare payment systems. While such systems can lower operating costs and speed boarding times, they also have the potential to exclude some riders and undermine both individual access and transit ridership. Emerging fare payment models require riders to have access to banking, credit and debit cards and in some cases use their smartphones, data plans and Internet connections to purchase and store tickets. Many riders may not have access to these resources and thus be potentially excluded from riding. These potentially excluded individuals often come from the least advantaged groups in society, including those with lower income and education levels. Age may also be a factor in exclusion, as new fare payment technologies such as mobile ticketing require technological proficiency and trust of online payment systems, which often varies by age. This study explores the barriers that riders and non-riders face when paying for transit by these means, how these barriers differ along lines of race/ethnicity, income, and age, and evaluates cost-effective and convenient solutions for addressing these barriers.

Prior research has identified some technologies and policies that could be used to better accommodate under- and unbanked riders in new fare payment systems. Such approaches include offering different types of prepaid cards, fare payment through retail networks, vending machines, and ticket offices, along with free public $\mathrm{Wi}-\mathrm{Fi}$, and better education and training on using smart payment systems. This project builds on these existing evaluation efforts by looking closely at payment behavior and access to banking, internet and smartphone technology in three metro areas. This project answers three specific research questions:

1. What is the prevalence and types of automated fare payment systems in the U.S. and what mitigation strategies have agencies adopted to address equity concerns of exclusion?

2. How do current payment systems serve riders who are: different ages, live or work in neighborhoods underserved by transit or other amenities, do not own smartphones or have readily available internet access, are under- or unbanked or face other barriers to transit access? How will these potentially excluded riders adjust to emerging automated fare payment technologies?

3. How cost effective are equity mitigation strategies used to include potentially excluded riders? How do these strategies affect agency costs and revenues, and how do they improve access and equity?

A review of existing literature and transit agencies statistics suggests that the groups most likely to be affected by the transition to cashless fare payment systems are seniors, those with lower income levels, those with lower education levels, members of ethnic or racial minority groups, or those with limited English proficiency. Finally, our review briefly highlighted similar equity challenges and potential solutions from other 
modes like bikesharing, which are important considerations for transit agencies as they explore first mile/last mile partnerships.

Following on our literature review, we carried out original field research in two phases. First, we engaged transit users about their experiences with emerging technologies through focus group discussions. Second, we conducted a larger sample survey to measure the prevalence of barriers to using cash-less technologies among existing transit riders. We conducted this research across the three regions of focus for this project: Portland-Gresham, Oregon; Eugene, Oregon; and Denver, Colorado.

Overall, results from our survey and focus groups show that transit riders are similarly resourced to the general population (Apaam, 2018; Pew, 2019), and in some ways even better prepared for automated payment systems. Still, our investigation reveals some significant barriers and disparities among current transit riders, including the following:

- A significant number of riders ( $30 \%)$ still rely heavily on paying cash onboard buses.

- Those who currently pay cash on-board appeared able to switch to other cash and non-cash options, though a significant number imagine they will continue to rely only on cash, while a small number claim they would not be able to ride any longer.

- Overall, smartphone ownership is high (over $80 \%$ ) for all groups, other than Boomers (over 55 years old).

- A small but significant number ( 20\%) are concerned about reaching cell phone data limits.

- A significant number ( $30 \%)$ depend on nontraditional sources for phone data such as public Wi-Fi for Internet connectivity.

- There is general unease with using automated payment systems requiring credit information to be stored or input into websites or phones.

- High income respondents typically had higher access to smartphones, Internet connectivity, and financial services.

- Modeling showed higher incomes predicted a lower likelihood to pay cashon-board, controlling for other factors.

- Older respondents had significantly lower access to smartphones and Internet connectivity.

- Modeling revealed that access to credit cards and comfort using automated payment systems predicted lower reliance on cash-on-board payment.

A significant takeaway is that local conditions and patterns will differ substantially from national averages and therefore authors recommend doing local survey work to understand particular rider issues with these transitions. Based on these general results, it seems that outreach, education and training will be an important element of improving adaptation to new fare payment systems. Results revealed that credit card access and greater comfort using emerging automated payment systems (either on-line or through a smartphone) significantly predicted lower cash-on-board use, controlling for factors such as income, smartphone access, frequency of use, and other factors. While 
public agencies may have difficulty expanding access to credit cards, improving understanding and comfort using payment systems seems achievable through expanded outreach, partnerships with community organizations, and training programs.

Results also showed that concern over phone data limits moderately predicted cash-onboard payment, controlling for other factors, and so free public Wi-Fi near or on transit could also offer an important improvement for those who are dependent on Wi-Fi hotspots, especially those who may live or work far from stores, libraries or cafes which offer such services. Finally, for older adults, a smartphone program and training may be needed to close the gap in smartphone access and use and proficiency, especially if they are going to be using transit more as they phase out of driving themselves as they age.

A final set of research questions for this project relate to the effect and costs of mitigation efforts to reduce rider exclusion across cash-based and cash-less fare scenarios. We ask: 1) how effective are proposed mitigations at including potentially excluded riders? , 2) how costly are these mitigations?, and 3) therefore, how costeffective are they? To answer these questions we developed a cost-benefit spreadsheet model integrating a qualitative assessment of equity impacts with a quantitative model of costs and revenues. The model was built using unit costs from industry experts, along with other parameters of ridership and system size, etc.

We used the model to explore and compare four scenarios along with an additional base (no-cash) case. Each scenario includes a different cash acceptance configuration of the on-board (bus) fareboxes, ticket vending machines (TVMs), and retail cash acceptance rates and costs. These scenarios included:

Base - No cash accepted anywhere)

Scenario 1 - No cash anywhere, adds retail network

Scenario 2 - Cash on board, not at TVMs, no retail

Scenario 3 - Cash only at TVMs, no retail

Scenario 4 - Cash accepted everywhere

We used our cost-benefit model to explore the cost effectiveness of these scenarios in our three case cities. The model highlighted some general takeaways that are important for navigating the transition to reducing cash in fare payments. Perhaps not surprisingly, our larger metro areas profiled here, Portland-Gresham and Denver, spend much less (per boarding) to collect fares than smaller ones. This is salient because both the total and marginal costs of adding cash collection capabilities are important factors in decision-making around equity mitigations. Indeed, all the mitigations we profile here cost much less than the fares they collected. But the larger agencies have a lower threshold to justify adding equity mitigations, as they are amortized over more boardings compared to smaller agencies. If equity is truly the goal, then agencies should strive to add these capabilities for as long as reasonably possible into the future. 
The next conclusion from this pattern is that for smaller agencies, they should seriously consider going completely fare-free. Across the board, our Eugene case showed that fare collection consumes a large part of fare revenues - about $40 \%$ of the revenues in the full cash scenario are spent collecting fare. This approach obviously would benefit low income riders and those potentially excluded by technological transitions, but benefit all riders as well.

Our analysis shows that simple cash collection on board buses is perhaps the least costly way of expanding cash collection capabilities. According to the ridership survey data, this mitigation also added significant ridership.

Based on the unit cost research we included in our models, retail is by far the lowest cost option to add cash capabilities in terms of total cost, net costs, and in terms of cost to accommodate potentially excluded riders. It was the most commonly cited mitigation from our interviews with agencies. Our assumptions, however is that the retail network still poses significant geographical barriers for many riders, and does not offer the kind of coverage and access that cash collection on-board would offer. Still, for the larger regions, the costs of moving from retail to cash on-board was only about $50 \%$ more per accommodated rider (and much less than fares collected) and so should still be considered, perhaps alongside retail. For Eugene, however, moving from retail to cash on-board raised costs per accommodated rider quite significantly. Overall, the larger number of riders that are potentially excluded, the bigger impact equity mitigations have and the cheaper they are per accommodated rider. 


\section{INTRODUCTION AND BACKGROUND}

Transit agencies are increasingly adopting cashless fare payment systems. While such systems can lower operating costs and speed boarding times, they also have the potential to exclude some riders and undermine both individual access and transit ridership. The fast pace of change in transit fare technology necessitates a comprehensive study of the prevalence of automated payment in the U.S., barriers that riders and non-riders face to paying for transit by these means, how these barriers differ along lines of race/ethnicity, class and other social dimensions, and cost-effective and convenient solutions for addressing these barriers.

New fare payment systems fall into two emerging models. In the first, "open payments systems," fare is paid via contactless bankcards or mobile wallets directly at gates, vending machines and fareboxes. This means that riders do not have to purchase a ticket or load a transit-only card before riding. The second model, often called 'mobile ticketing,' enable riders to purchase and store tickets on their smartphones with a credit card, debit card, or other electronic payment linked to the phone. Either of these models require riders to have access to banking, credit and debit cards and in some cases use their smartphones, data plans and Internet connections to purchase and store tickets. Many riders may not have access to these resources and thus be potentially excluded from riding. These potentially excluded individuals often come from the least advantaged groups in society, including those with lower income and education levels. Age may also be a factor in exclusion, as mobile ticketing requires technological proficiency and trust of online payment systems which often varies by age.

Prior research has identified some technologies and policies that could be used to better accommodate under- and unbanked riders in new fare payment systems. Such approaches include offering different types of prepaid cards, fare payment through retail networks, vending machines, and ticket offices, along with free public Wi-Fi, and better education and training on using smart payment systems. This project will build on these existing evaluation efforts by looking closely at payment behavior and access to banking, internet and smartphone technology in three metro areas. This research will answer three specific research questions:

4. What is the prevalence and types of automated fare payment systems in the U.S. and what mitigation strategies have agencies adopted to address equity concerns of exclusion?

5. How do current payment systems serve riders who are: different ages, live or work in neighborhoods underserved by transit or other amenities, do not own smartphones or have readily available internet access, are under- or unbanked or face other barriers to transit access? How will these potentially excluded riders adjust to emerging automated fare payment technologies?

6. How cost effective are fare technologies and their associated equity mitigation strategies? Here we will look at both agency costs and revenues, along with strategies' ability to improve access and equity. 
Results from this research will inform practitioners and policymakers seeking to balance new fare technology adoption with concerns about equity and inclusion on transit. The project was carried out, and will be presented here, in several tasks.

In Task 1, presented in Chapter 2, we conduct a review of literatures related to fare payment, automation, and equity. In Task 2, presented in Chapter 3, we do field research to better understand the challenges and potential strategies of addressing equity concerns in automated fare payment adoption. Data collection efforts focus on the three subject cities Portland-Gresham, Eugene, and Denver. In Task 3, presented in Chapter 4, two effectiveness frameworks are developed from a user and agency standpoint. In Task 4, presented in Chapter 5, we use our framework to analyze several case approaches to preserve or expand cash payment capabilities for the three cities in which we worked. Finally, in Task 5, presented in Chapter 6, we draw final conclusions by reflecting on the results of our case evaluations and the other information from our survey, focus group discussions and literature review. 


\section{LITERATURE REVIEW}

In this task, we examine the existing literature on automated fare payment technologies and the general migration to cashless fare payment systems. We also summarize the existing research on barriers to automated fare payment systems such under- and unbanked transit riders, and groups with limited access to smartphones or restricted use of data plans. These findings assisted our team with the refinement of data collection methodology employed in Task 2 and the development of the cost effectiveness frameworks in Tasks 3-5.

\subsection{Trends in Transit Fare Payment Technology}

Prior research on new fare payment systems identified at least two emerging models of fare collection. The first is generally referred to as open payment systems. In an open payment system, transit agencies accept fare payment via contactless bank cards directly at the gates in rail stations and upon boarding buses. This means that transit riders do not have to purchase a ticket or load a transit-only smart card before riding. Instead, the costs of their trips are billed to them via their debit or credit card accounts (Brakewood and Kocur, 2011; Wallischeck et al., 2015). Different transit agencies around the United States have implemented this type of payment system, including the Chicago Transit Authority, New York City's Metropolitan Transportation Authority (MTA), and Portland's Tri-County Metropolitan Transportation District of Oregon (TriMet).

The second model of new fare payments is often called mobile ticketing. Mobile ticketing systems enable riders to purchase tickets directly on their smartphones with a credit card, debit card, or other electronic payment (Figure 2.1). Agencies then have several validation options, such as visually inspecting the smartphone ticketing screen or scanning a ticketing barcode with a handheld device (Brakewood et al., 2014; Georggi et al., 2017; Rahman, Wong and Brakewood, 2016). The adoption of mobile fare payments is a growing trend in the transit industry in the US; there are 100 plus agencies across the USA that have mobile fare payment applications (Brakewood, 2020). 


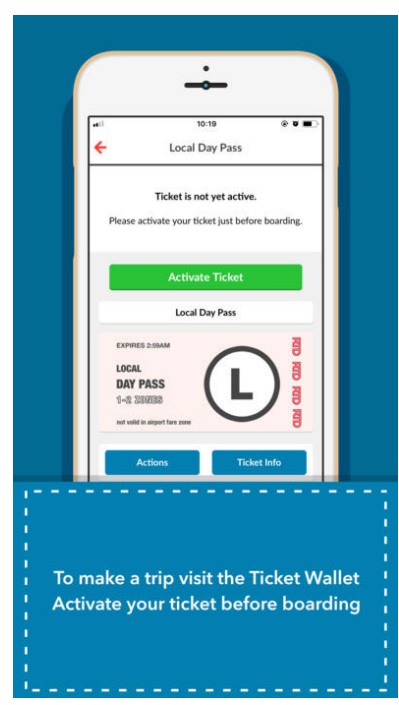

Figure 2.1: Denver RTD mobile fare payment application Adapted from Denver RTD Website

It is worth noting that some agencies offer both open payment systems and mobile ticketing on their system. However, the convergence of these two models has begun to happen in some transit systems where near field communications (NFC) technology on mobile phones can be used to "tap" smartphones directly at gates in stations or upon boarding buses to pay fares (Wallischeck et al., 2015) (see left picture in Figure 2.2). Transit agencies are beginning to adopt this technology. For example New York City's MTA started to accept Apple Pay, Google Pay, Samsung Pay, and Fitbit Pay in 2019 (Marshall, 2019). Furthermore, in Portland, TriMet riders can now add their transit passes to mobile wallet and then pay for transit using Apple Pay or Google Pay functionality (see right picture in Figure 2.2) (Altstadt, 2019; Trimet, 2021). 


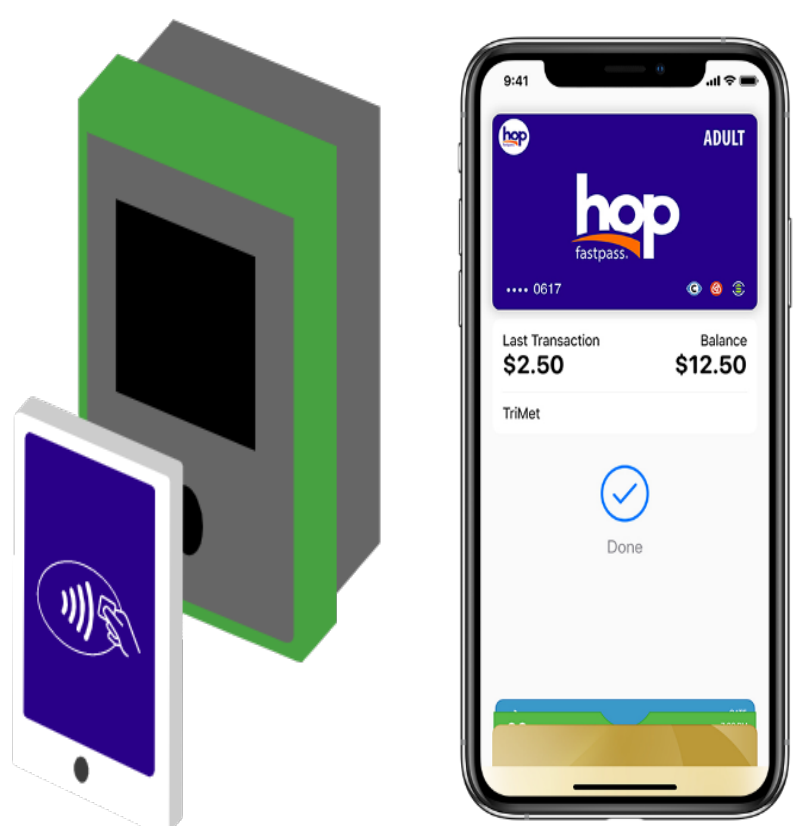

Figure 2.2 NFC Payment technology for transit fares Adapted from TriMet Website

The adoption of these new fare payment technologies is expected to benefit both transit riders' and agencies. The main anticipated benefits for transit users are:

- Travel time savings;

- Convenience;

- Ease of access; and

- More flexible fares.

The expected benefits for transit agencies include:

- Lower fare collections costs;

- Performance improvements;

- Improved travel data;

- Reduced dwell time;

- The ability to introduce fare capping;

Fare Capping: the transit agency "caps" the maximum amount a rider can pay in a given period. For daily capping, riders never pay more than the total cost of a day pass.

- Transition to Mobility as a Service (MaaS) platforms; and

- Increased integration between the different transit modes and transportation agencies (Brakewood, 2010; CH2M Hill, 2017)

Transit agencies across the United States are in different stages of adopting new fare payment technologies. A survey conducted by the American Public Transportation Association (APTA) public transportation in 2018 showed that $60.6 \%$ of participating agencies (100 of 165) offer their customers the ability to purchase bus tickets through the agency's or another organization's website. $25.45 \%$ of these agencies (42 of 165) have mobile applications for bus fare payments. The number of transit agencies that have adopted open payment systems was only 25 , which represents $15.15 \%$ of the agencies that participated in the survey (Dickens, 2019). 
This transition to using new technologies brings some challenges for transit agencies. In particular, the replacement of cash-based fares raises serious equity concerns, which is the focus of this study. The next sections discuss the main obstacles to implementing cashless transit fare payment systems discussed in the literature.

\subsection{OBSTACLES TO CASHLESS FARE PAYMENTS}

This section discusses some of the main challenges to implementing cashless fare payment systems, with an emphasis on equity. Three key challenges were identified in the prior literature and by reviewing popular press articles. These include serving underbanked and unbanked populations of transit riders, inclusion of riders without smartphones, and potential pushback from local jurisdictions if cashless is implemented.

\subsubsection{Underbanked and Unbanked Riders}

The first potential equity concern with implementation of cashless fare payment systems is how to serve unbanked and underbanked users, whom have little or no access to banking services. The Federal Deposit Insurance Corporation (FDIC) defines unbanked as households in which "no one in the household had a checking or savings account" (Apaam et al., 2018). The FDIC defines underbanked as households "that have a checking or savings account and used one of the following products or services from an alternative financial services (AFS) provider in the past 12 months: money orders, check cashing, international remittances, payday loans, refund anticipation loans, rent-to-own services, pawn shop loans, or auto title loans" (Apaam et al., 2018). These two definitions show that both unbanked or underbanked households depend mainly on cash and might not have access to credit/debit cards, which may be necessary in cashless transit fare payment systems.

Unbanked Households: "no one in the household had a checking or savings account"

Underbanked Households: "that have a checking or savings account and used one of the following products or services from an alternative financial services (AFS) provider in the past 12 months: money orders, check cashing, international remittances, payday loans, refund anticipation loans, rent-to-own services, pawn shop loans, or auto title loans"

The FDIC also conducts national surveys of unbanked and underbanked households, and recent results have revealed that the percent of unbanked households nationwide has been continuously declining since 2011 . Figure 2.3 shows that the percent of unbanked household nationwide dropped from $8.2 \%$ in 2011 to $6.5 \%$ in 2017 (Apaam et al., 2018). This reduction suggest that more households nationwide are gaining access to some kind of banking services over time. Figure 2.3 also shows that $4.2 \%$ of the households in both Colorado and Oregon (which are the locations of subsequent parts of this study) were unbanked in 2017 , which is lower than the nationwide average. 


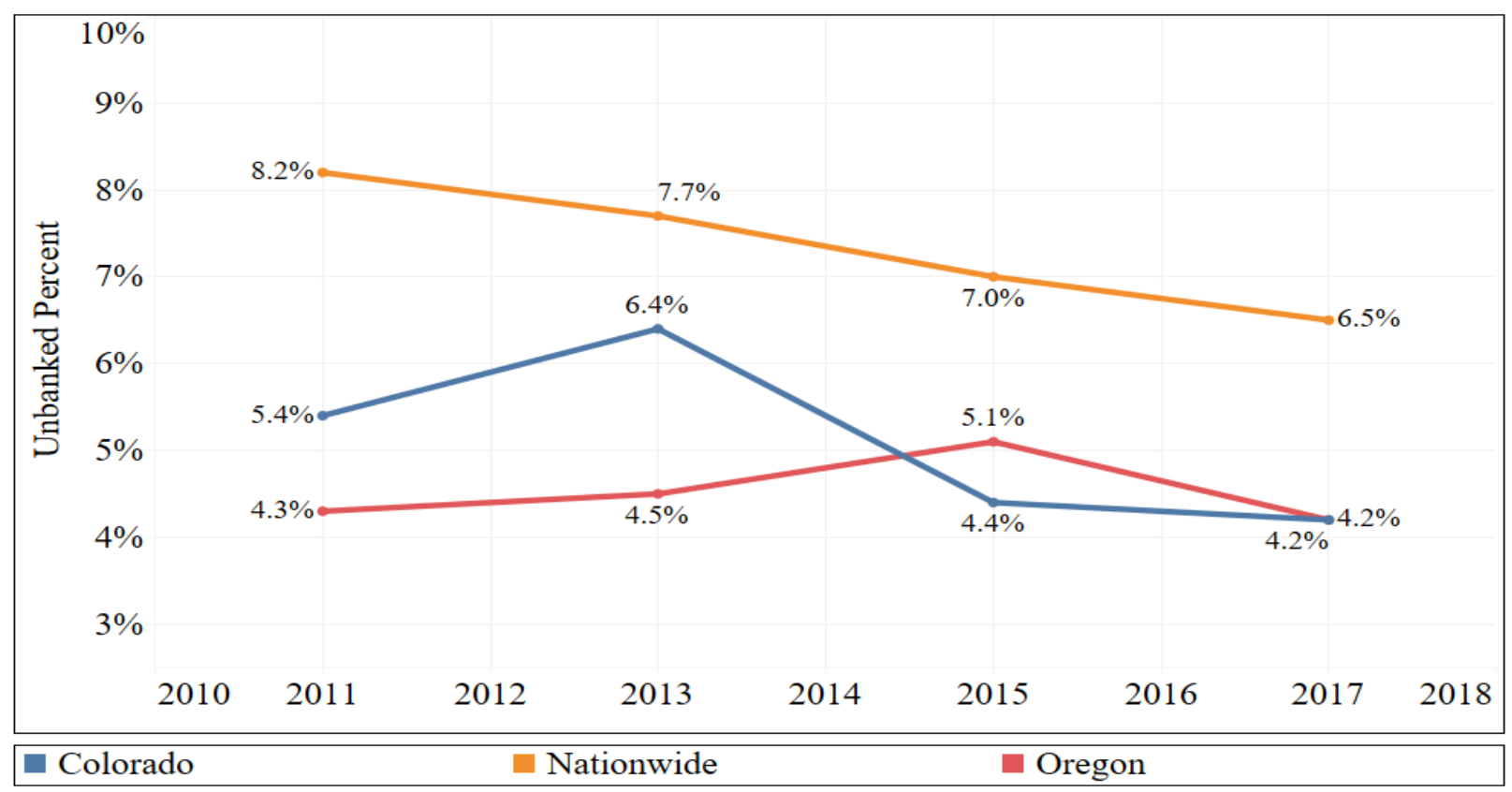

Figure 2.3: Percent of unbanked households over time Figure made by authors using data from the FDIC 2017 national survey (Apaam et al., 2018)

The results of the FDIC nationwide survey were also used to compile Figure 2.4, which compares household banking status percentages for Colorado and Oregon to nationwide statistics. Figure 2.4 shows that $68.4 \%$ of the households are fully banked nationwide. Colorado and Oregon had slightly higher percentages of fully-banked household than the nationwide average at $70.9 \%$ and $69.3 \%$, respectively (Apaam et al., 2018). However, in both states, about one-third of households were either unbanked or underbanked, which indicates that banking access will remain a major challenge for transit agencies transitioning to cashless fare payments. 


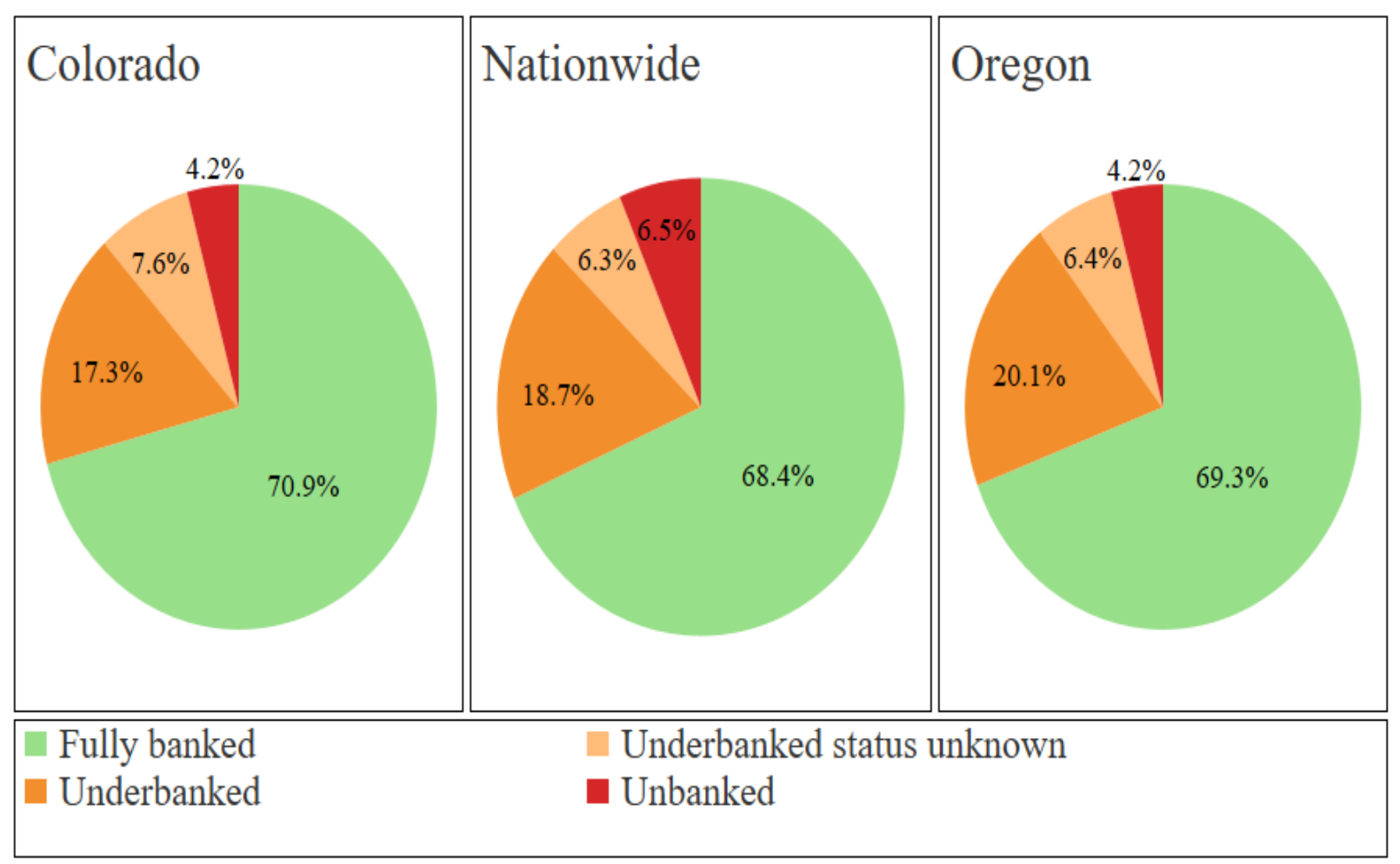

Figure 2.4: Banked, underbanked, and unbanked statistics Figure made by authors using data from The FDIC 2017 national survey (Apaam et al., 2018)

The FDIC 2017 national survey also explored household banking status by household socioeconomic characteristics, as shown in Table 2.1. This reveals that banking status is not equal across demographic groups. The first rows of Table 2.1 reveal that the portion of unbanked and underbanked households is considerably large for younger age groups. For example, nearly $40 \%$ of the age group 15 to 24 years and over $30 \%$ of the age group 35 to 44 years are either unbanked or underbanked (summed cumulatively).

The second set of rows in Table 2.1 reveal differences by race/ethnicity. Notably, a higher percentage of Black (approximately $47 \%$ cumulatively) and Hispanic (about $43 \%$ ) households were either unbanked or underbanked. This can be compared to Asian households and White households that have much lower percentages (about $20 \%$ and $17 \%$, respectively).

Last, Table 2.1 reveals noteworthy differences by household income and education level. The third set of rows indicates that more than half of the households with annual income levels less than $\$ 15,000$ were either unbanked or underbanked, which can be compared to only about $14 \%$ of households earning at least $\$ 75,000$ per year. Furthermore, more than $50 \%$ of the households with less than high school diploma were either unbanked or underbanked (Apaam et al., 2018). 
Table 2.1: 2017 Nationwide Household Banking Status by Household Characteristics Adapted from 2017 the FDIC national survey (Apaam et al., 2018)

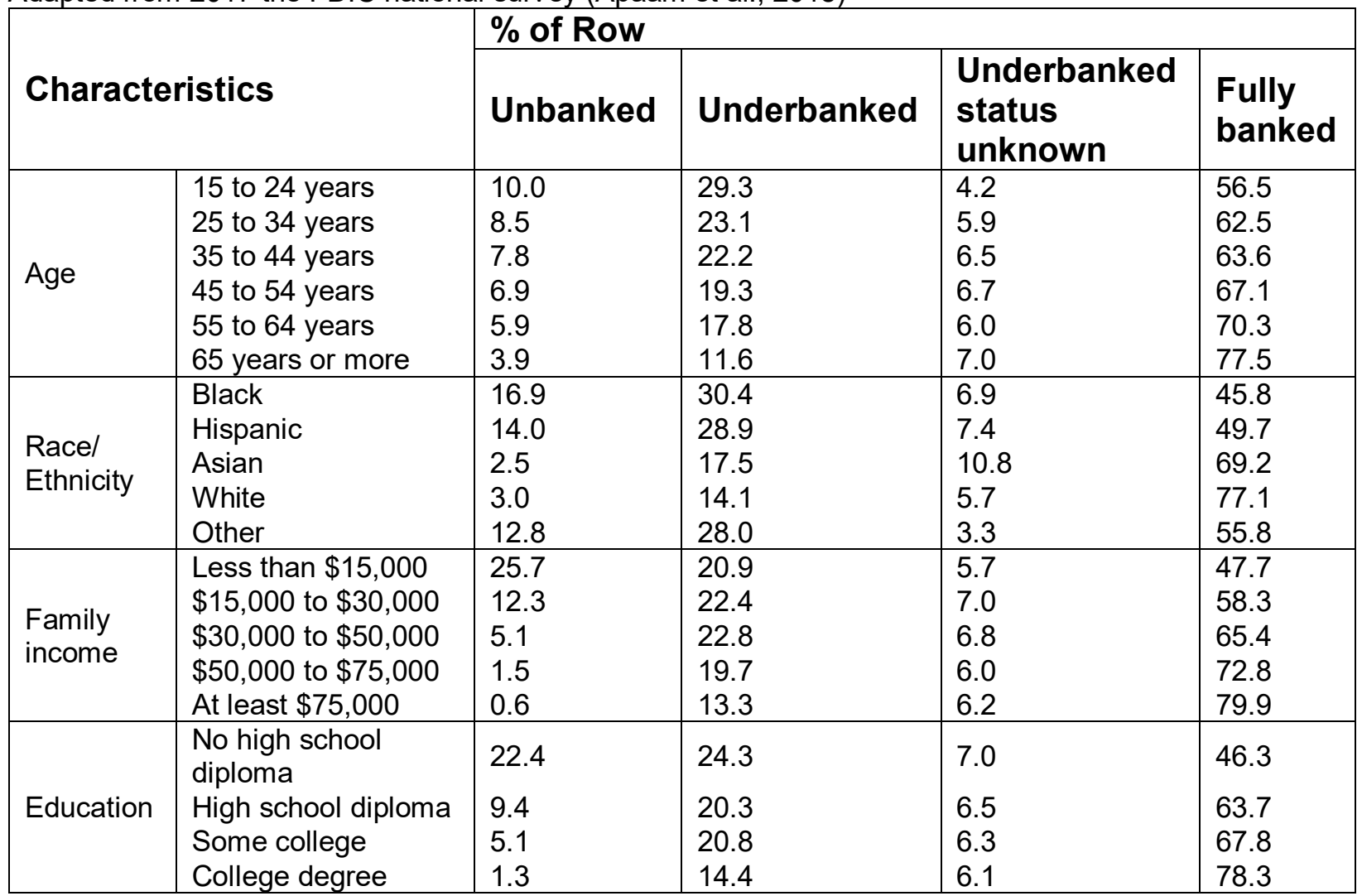

The nationwide statistics collected by the FDIC shown in Table 2.1 may differ from those that ride public transit, which is the focus of this study. To the best of the authors' knowledge, there is only one prior academic study that considered the banking status of transit riders in the United States. This study was conducted by surveying riders of the Chicago Transit Authority (CTA), and the results are shown in Table 2.2 (Brakewood, 2010). Similar to nationwide trends, there are noteworthy differences in banking access among racial/ethnic groups, by education level, and by income level for these transit riders. Specifically, unbanked riders at the CTA tended to have annual household incomes that were less than $\$ 30,000$, many identified as Black/African American, and a relatively high proportion had a high school degree or less, as shown in Table 2.2. 
Table 2.2: CTA banked and unbanked rider statistics

Adapted from (Brakewood, 2010)

\begin{tabular}{|c|c|c|c|c|c|}
\hline \multirow{2}{*}{\multicolumn{2}{|c|}{ Characteristics }} & \multicolumn{2}{|l|}{ Banked } & \multicolumn{2}{|l|}{ Unbanked } \\
\hline & & \multirow{2}{*}{$\begin{array}{l}\begin{array}{l}\text { Count } \\
\text { (weighted) }\end{array} \\
1,900\end{array}$} & \multirow{2}{*}{$\begin{array}{l}\% \text { of } \\
\text { Column } \\
100\end{array}$} & \multirow{2}{*}{\begin{tabular}{|l|}
$\begin{array}{l}\text { Count } \\
\text { (weighted) }\end{array}$ \\
475
\end{tabular}} & \multirow{2}{*}{$\begin{array}{l}\% \text { of } \\
\text { Column } \\
100\end{array}$} \\
\hline & All Respondents & & & & \\
\hline \multirow{8}{*}{ Age } & $16-17$ & 21 & 1 & 59 & 12 \\
\hline & $18-24$ & 141 & 7 & 69 & 15 \\
\hline & $25-34$ & 328 & 17 & 63 & 13 \\
\hline & $35-44$ & 367 & 19 & 68 & 14 \\
\hline & $45-54$ & 381 & 20 & 75 & 16 \\
\hline & $55-64$ & 337 & 18 & 54 & 11 \\
\hline & $\geq 65$ & 12 & 1 & 85 & 18 \\
\hline & No answer & 310 & 16 & 2 & 0 \\
\hline \multirow{8}{*}{$\begin{array}{l}\text { Race/ } \\
\text { Ethnicity }\end{array}$} & White/Caucasian & 1,153 & 61 & 130 & 27 \\
\hline & Black/African American & 526 & 28 & 250 & 53 \\
\hline & $\begin{array}{l}\text { American Indian/Alaskan } \\
\text { Native }\end{array}$ & 30 & 2 & 9 & 2 \\
\hline & Asian /Pacific Islander & 91 & 5 & 13 & 3 \\
\hline & Hispanic & 103 & 5 & 71 & 15 \\
\hline & Other & 38 & 2 & 16 & 3 \\
\hline & Don't know & 4 & 0 & 3 & 1 \\
\hline & Refused & 33 & 2 & 7 & 2 \\
\hline \multirow{11}{*}{$\begin{array}{l}\text { Annual } \\
\text { income }\end{array}$} & Less than $\$ 10,000$ & 90 & 5 & 87 & 18 \\
\hline & $\$ 10,000$ to $\$ 20,000$ & 121 & 6 & 61 & 13 \\
\hline & $\$ 20,000$ to $\$ 30,000$ & 126 & 7 & 62 & 13 \\
\hline & $\$ 30,000$ to $\$ 35,000$ & 80 & 4 & 21 & 4 \\
\hline & $\$ 35,000$ to $\$ 45,000$ & 133 & 7 & 18 & 4 \\
\hline & $\$ 45,000$ to $\$ 55,000$ & 122 & 6 & 10 & 2 \\
\hline & $\$ 55,000$ to $\$ 65,000$ & 144 & 8 & 26 & 6 \\
\hline & $\$ 65,000$ to $\$ 85,000$ & 212 & 11 & 17 & 4 \\
\hline & $\$ 85,000$ to $\$ 125,000$ & 234 & 12 & 12 & 3 \\
\hline & Above $\$ 125,000$ & 246 & 13 & 23 & 5 \\
\hline & Refused & 392 & 21 & 137 & 29 \\
\hline \multirow{6}{*}{$\begin{array}{l}\text { Education } \\
\text { level }\end{array}$} & Less than high school & 99 & 5 & 148 & 31 \\
\hline & High school/GED & 196 & 10 & 126 & 27 \\
\hline & Some College/Associates & 524 & 28 & 115 & 24 \\
\hline & Bachelor's degree & 530 & 28 & 47 & 10 \\
\hline & Post-Bachelor's Degree & 541 & 28 & 29 & 6 \\
\hline & No answer & 10 & 1 & 10 & 2 \\
\hline
\end{tabular}

\subsubsection{Smartphone Ownership}

In addition to bank access, many new fare payment technologies require access to a smartphone, which is another potential equity issue for cashless fare payment systems. A 2019 nationwide survey shows that $81 \%$ of adults in the United States have access to smartphones, which is substantially higher than amount in the $2011(35 \%)$ shown in Figure 2.5 (Pew Research Center, 2019). This dramatic increase reveals that while 
more Americans are gaining access to smartphones, around one-fifth of American adults still do not own a smartphone.

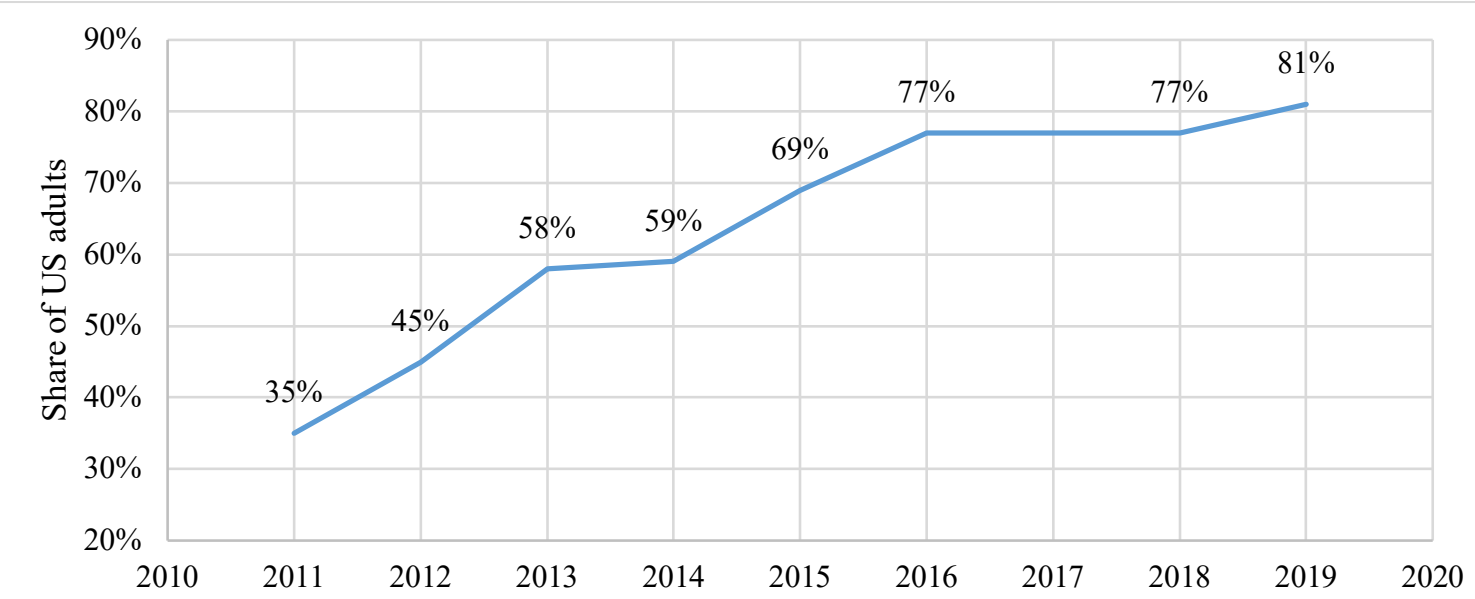

Figure 2.5: Percent of adults in the United States who own a smartphone Adapted from (Pew Research Center, 2019)

For transit riders specifically, at least one prior academic study has shown that smartphone ownership for transit riders may be higher than the nationwide average in some areas of the country. A 2014 study considered five different American transit agencies and concluded that four out of the five agencies had higher smartphone ownership levels than nationwide statistics, as shown in Figure 2.6 (Windmiller, Hennessy and Watkins, 2014).

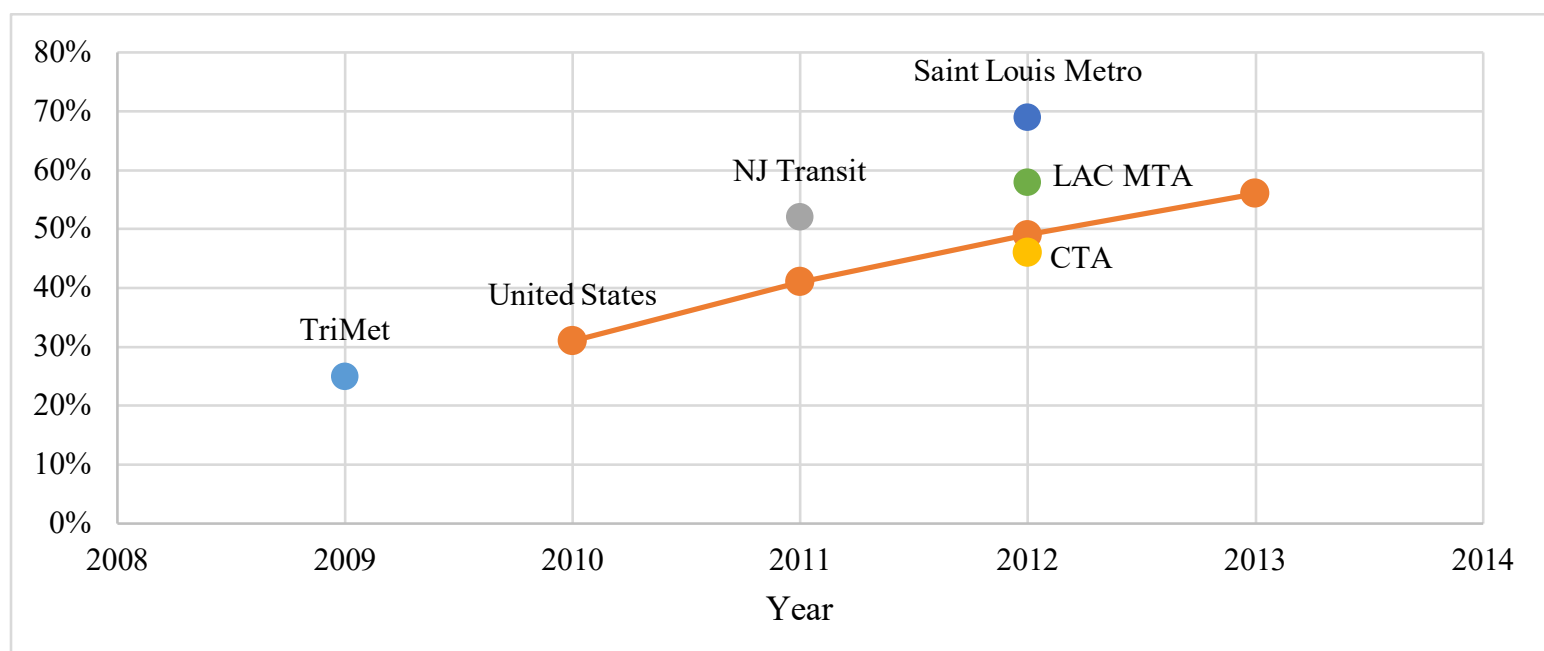

Figure 2.6: Smartphone ownership for the United States and transit riders Adapted from (Windmiller, Hennessy and Watkins, 2014)

In addition to academic literature, unpublished transit agency customer surveys can also provide insight into levels of access to smartphones. In Olympia, Washington, the 2015 Intercity Transit Customer Satisfaction Survey showed that $67 \%$ of the riders have access to smartphones (Clark et al., 2015), which is similar to nationwide average at 
that time. In 2016, the ownership of smartphones for PACE (suburban bus) and CTA (urban bus and rail) riders in the Chicago region were $74 \%$ and $84 \%$, respectively (RSG, 2017). In 2018, 87\% of TriMet riders in the Portland region indicated that they had a smartphone, which is higher than the national level of ownership at that time (DHM Research, 2018). However, smartphone ownership levels for Los Angeles Metro riders followed different trends; $73 \%$ of Metro rail users had access to smartphones and only $52 \%$ of the bus riders had smartphones, which are less than the nationwide average at the time (Metro Research, 2018). These statistics show that although the ownership of smartphones for transit riders in many cities is similar to the nationwide average, there are still some riders who have lower levels of smartphone access, which is potentially most concerning among bus riders (compared to rail riders).

Similar to banking access, nationwide smartphone ownership levels vary by demographic group, as shown in Table 2.3 (Pew Research Center, 2019). One of the greatest disparities in smartphone ownership is age. A nationwide survey showed that only $79 \%$ of people in the age group 50-64 own smartphones, while this percentage drops to $53 \%$ for people who are 65 or older (Pew Research Center, 2019). The results also reveal that low income households have less access to smartphones, as only $71 \%$ of people with annual household income levels less than $\$ 30,000$ own smartphones. Furthermore, the results show that people with lower education levels may have less access to smartphones; only $66 \%$ of people with less than a high school degree and $72 \%$ of people with a high school degree own smartphones. It is worth noting that this nationwide survey showed that the different ethnicities have similar smartphone ownership levels (Pew Research Center, 2019). Last, it should be noted that smartphone ownership also varies based on the geographic context (results not shown). People living in rural areas are less likely to have smartphones compared to people living in urban areas (Pew Research Center, 2019; Velaga et al., 2012). 
Table 2.3: Percent of Adults in the United States Who Own the Following Devices Adapted from (Pew Research Center, 2019)

\begin{tabular}{|l|l|l|l|}
\hline \multicolumn{2}{|l|}{ Characteristics } & Smartphone & $\begin{array}{l}\text { Cellphone, but not } \\
\text { smartphone }\end{array}$ \\
\hline & Nationwide & $\mathbf{8 1 \%}$ & $\mathbf{1 5 \%}$ \\
\hline Age & $18-29$ & $96 \%$ & $4 \%$ \\
& $30-49$ & $92 \%$ & $6 \%$ \\
& $50-64$ & $79 \%$ & $17 \%$ \\
& $65+$ & $53 \%$ & $39 \%$ \\
\hline Household & Less than $\$ 30,000$ & $71 \%$ & $23 \%$ \\
Income & $\$ 30,000-\$ 49,999$ & $78 \%$ & $18 \%$ \\
& $\$ 50,000-\$ 74,999$ & $90 \%$ & $8 \%$ \\
& $\$ 75,000+$ & $95 \%$ & $5 \%$ \\
\hline Education & Less than high school graduate & $66 \%$ & $25 \%$ \\
& High school graduate & $72 \%$ & $24 \%$ \\
& Some college & $85 \%$ & $11 \%$ \\
& College graduate & $91 \%$ & $7 \%$ \\
\hline Race/Ethnicity & White & $82 \%$ & $14 \%$ \\
& Black & $80 \%$ & $17 \%$ \\
& Hispanic & $79 \%$ & $17 \%$ \\
\hline
\end{tabular}

Smartphone ownership among the different groups of transit riders may follow trends similar to the nationwide figures. One early study of transit riders was conducted in Nassau County, Long Island (outside of New York City), and the results are shown in Table 2.4. A survey for NICE bus riders in Nassau County showed that more than half of riders older than 45 did not have access to smartphone. Moreover, the results of this study also showed that riders with annual household income levels less than $\$ 15,000$ have less access to smartphones (see Table 2.4) (Sion, Brakewood and Alvarado, 2016). 
Table 2.4: Smartphone ownership from the NICE Bus system-wide survey

Adapted from (Sion, Brakewood and Alvarado, 2016)

\begin{tabular}{|c|c|c|c|c|c|}
\hline \multirow{2}{*}{\multicolumn{2}{|c|}{ Characteristics }} & \multicolumn{2}{|c|}{ Yes Smartphone } & \multicolumn{2}{|c|}{ No Smartphone } \\
\hline & & \multirow{2}{*}{$\begin{array}{l}\text { Count } \\
5,337\end{array}$} & \multirow{2}{*}{\begin{tabular}{|l|}
$\%$ Row \\
67 \\
\end{tabular}} & \multirow{2}{*}{$\begin{array}{l}\text { Count } \\
2,613 \\
\end{array}$} & \multirow{2}{*}{$\begin{array}{l}\text { \% Row } \\
33\end{array}$} \\
\hline & All Respondents & & & & \\
\hline \multirow{7}{*}{ Age } & Under 16 & 35 & 71 & 14 & 29 \\
\hline & Age 16-18 & 429 & 79 & 112 & 21 \\
\hline & Age 19-24 & 1,537 & 85 & 261 & 15 \\
\hline & Age 25-44 & 1,998 & 73 & 755 & 27 \\
\hline & Age 45-64 & 1,036 & 49 & 1,072 & 51 \\
\hline & Age 65+ & 116 & 33 & 234 & 67 \\
\hline & $\mathrm{N} / \mathrm{A}$ & 186 & 53 & 165 & 47 \\
\hline \multirow{8}{*}{$\begin{array}{l}\text { Annual } \\
\text { Household } \\
\text { Income }\end{array}$} & Less than $\$ 15,000$ & 1,578 & 63 & 924 & 37 \\
\hline & $\$ 15,000$ to $\$ 24,999$ & 488 & 71 & 203 & 29 \\
\hline & $\$ 25,000$ to $\$ 34,999$ & 972 & 71 & 403 & 29 \\
\hline & $\$ 35,000$ to $\$ 49,999$ & 483 & 74 & 173 & 26 \\
\hline & $\$ 50,000$ to $\$ 74,999$ & 627 & 74 & 218 & 26 \\
\hline & $\$ 75,000$ to $\$ 99,999$ & 250 & 76 & 77 & 24 \\
\hline & $\$ 100,000$ or more & 179 & 84 & 33 & 16 \\
\hline & $\mathrm{N} / \mathrm{A}$ & 760 & 57 & 582 & 43 \\
\hline \multirow{8}{*}{ Ethnicity } & Hispanic/Latino & 1,404 & 70 & 605 & 30 \\
\hline & White & 504 & 56 & 392 & 44 \\
\hline & Asian & 362 & 66 & 184 & 34 \\
\hline & Black/African American & 2,307 & 70 & 1,001 & 30 \\
\hline & American Indian/Alaskan & 45 & 48 & 48 & 52 \\
\hline & Hawaiian/Pacific Islander & 35 & 69 & 16 & 31 \\
\hline & Other / Multiple races & 287 & 79 & 75 & 21 \\
\hline & $\mathrm{N} / \mathrm{A}$ & 393 & 57 & 292 & 43 \\
\hline
\end{tabular}

Similar to NICE bus system riders, transit riders older than 40 years of age in Saint Louis, Missouri have less access to smartphones, as was revealed by an early study (Table 2.5) (Windmiller, Hennessy and Watkins, 2014). 
Table 2.5: Percentage of bus riders with access to smartphones in Saint Louis

Table made by authors using data from (Windmiller, Hennessy and Watkins, 2014)

\begin{tabular}{|l|l|l|}
\hline Age & Bus Riders & Rail Riders \\
\hline 18 or younger & $72 \%$ & $69 \%$ \\
\hline $19-24$ & $83 \%$ & $81 \%$ \\
\hline $25-30$ & $80 \%$ & $77 \%$ \\
\hline $31-35$ & $78 \%$ & $71 \%$ \\
\hline $36-40$ & $69 \%$ & $70 \%$ \\
\hline $41-45$ & $60 \%$ & $62 \%$ \\
\hline $46-50$ & $60 \%$ & $58 \%$ \\
\hline $51-64$ & $50 \%$ & $58 \%$ \\
\hline$\geq 65$ & $57 \%$ & $49 \%$ \\
\hline
\end{tabular}

Taken together, these prior studies suggest that smartphone ownership can vary based on age, income, race, and level of education, and that there are potential differences between regions. Therefore, transit agencies should consider these differences and account for the local context as they plan for the transition to cashless payments.

One final related challenge that has not been widely considered in the prior literature on smartphone ownership is access to data plans. Even when smartphones are present in the household, the user may not have a regular data plan due to the ongoing expense of paying for data. One prior study considered this and found that forty-four percent of smartphone users lost service at some point due to financial constraints. Furthermore, some users are more likely to cancel or lose their service than others like lower income, Black, and Latino users (Smith et al., 2015).

\subsubsection{Pushback from Jurisdictions}

A third potential challenge for cashless transit fare payment systems is pushback from local jurisdictions like the State New Jersey, the City of San Francisco, the City of Philadelphia, and New York City. In 2019, these localities each passed laws to ban or penalize cashless stores, citing discrimination against unbanked and underbanked households. Figure 2.7 shows that several jurisdictions took steps against cashless stores over the past year, which suggests that this is a growing trend. Additional jurisdictions like Washington, D.C. and the City of Chicago are currently considering banning cashless stores (Allen, 2019; Brinklow, 2019; Geuss, 2019; Mavadiya, 2019).

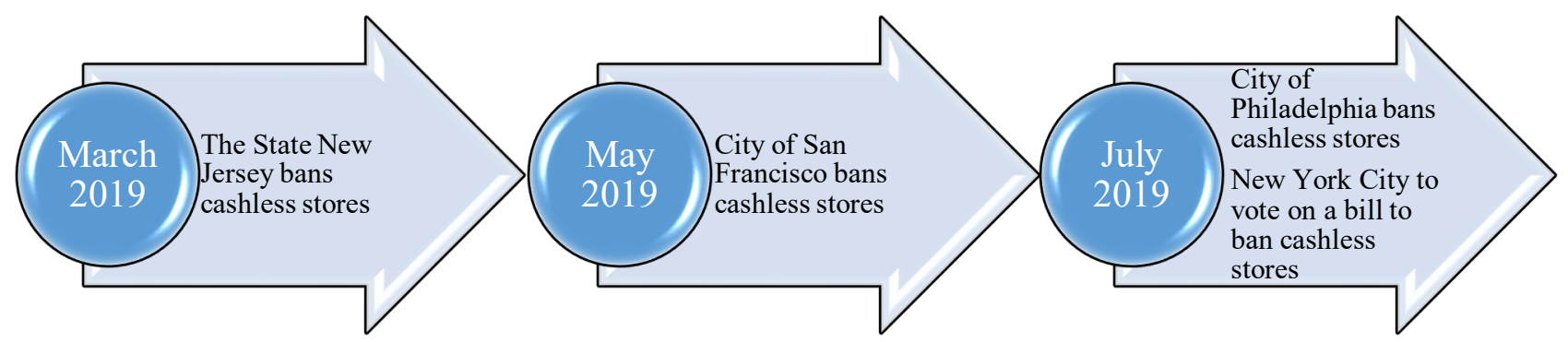

Figure 2.7: Timeline of laws against cashless stores 


\subsection{TRANSIT AGENCY EXAMPLES THAT ADDRESS EQUITY}

As transit agencies around the United States are taking steps towards cashless fare, many agencies around the world have already moved to fully cashless systems, such as Transport for London's buses and GVB public transport in Amsterdam. (GVB Public Transport, 2018; Transport for London, 2014). Other international agencies are on the way to cashless; for example, the Land Transport Authority (LTA) and TransitLink in Singapore are planning to go cashless by 2020 (Bhunia, 2017). However, due to different financial regulations in other countries, the experiences of these international transit agencies will not be discussed in detail in this report.

In the United States, Dallas Area Rapid Transit (DART) is using a phased approach to minimize, and potentially eliminate, cash fare payments for their transit system. This approach began in 2013 as DART launched their GoPass application (or "app"), which enables transit riders to buy transit passes using credit or debit cards on their smartphones. In 2018, DART partnered with PayNearMe to enable users to purchase transit passes using cash at the PayNearMe network of retailers, which includes 7Eleven, ACE Cash Express, and Family Dollar stores (PayNearMe, 2016; PayNearMe, 2018). This is an important partnership because many Dallas residents may be unbanked; it is estimated that $15.6 \%$ of households in Dallas do not have a bank account (Formby, 2016; PayNearMe, 2016).

Similar to DART, TriMet in Portland is gradually reducing cash fare payaments as they expand their electronic fare system known as Hop Fastpass. The Hop Fastpass is an account-based system that allows transit users to pay for transit fares throughout the Portland-Vancouver region. Hop Fastpass first launched physical contactless cards in July 2017; these wereavailable at many local retailers as reloadable cards. Shortly after the launch of the Hop Fastpass, Portland transit riders were able to pay for their fares using contactless credit/debit cards. Following the introduction of Hop FastPass, TriMet began allowing users to pay for their fares using Apple Pay, Google Pay, and Samsung Pay. As of May 2019, Hop Fastpass users could add their Hop card to Apple Wallet, which allows iPhone users to pay for their fares by holding their unlocked phones/watches near the fare reader (Altstadt, 2019; Altstadt, 2017). Concurrently with these advancements, TriMet announced that it will phase out most of their non-Hop paper tickets and passes by the end of $2019{ }^{1}$ (Altstadt, 2019). Although these developments were not part of a fully cashless system, they offered several options to reduce cash handling onboard while continuing to serve cash users through hundreds of stores in the region.

Washington Metropolitan Area Transit Authority (WMATA) is investigating the effects of cashless fare payment on bus speeds through a pilot program conducted on Bus Route 79 MetroExtra for the period from June 2018 to June 2019. WMATA stopped accepting cash payments on buses on this single route; instead, riders had to use a SmarTrip

${ }^{1}$ During the summer of 2020, TriMet went fully cashless in response to the COVID-19 pandemic. However, cash fares were re-instated on buses as of October 2020. https://trimet.org/fares/howtopay.htm 
contactless card. Riders could load money into their SmarTrip cards using one of the following methods: online; in any Metrorail station; at commuter stores; or at retail locations like Walmart, Giant foods, and CVS. (Washington Metropolitan Area Transit Authority, 2019; Washington Metropolitan Area Transit Authority, 2018). The results of this pilot were not publicly available at the time of writing; however, WMATA is expecting shorter vehicle dwell times and potentially higher bus speeds (Nelson, 2018).

\subsection{MULTI-MODAL CONNECTIONS TO TRANSIT}

As transit agencies explore first-mile-last-mile solutions and other multi-modal partnerships, understanding the equity challenges that face the users of these other modes is likewise important for transit agencies. Findings of prior equity-related studies for other transportation modes including taxicabs, transportation network companies (TNCs), and bikesharing are discussed in this section.

\subsubsection{Taxis and Transportation Network Companies (TNCs)}

This section highlights some of the prior studies that discussed aspects of the equity challenges that face taxicabs and transportation network companies (TNCs). King and Saldarriaga (2017) studied taxicab fare payments by neighborhood in New York City. The authors found that cash payments are associated with the percentage of immigrant households and the amount of unbanked households in the neighborhood (King and Saldarriaga, 2017).

Regarding TNCs, Shirgaokar (2018) investigated how to expand the mobility of seniors (over 64 years) using TNCs. This study recommended different actions by TNCs, community groups, and the government to take in order to improve seniors' accessibility to these services. These recommendations include providing better brand information on vehicles, more detailed driver information, enabling bookings by phone, accepting cash payments, and maintaining a complaints hotline (Shirgaokar, 2018).

The results of these two studies suggest that taxicabs and TNCs both face some equity challenges, particularly pertaining to cash payments.

\subsubsection{Bikesharing}

This section briefly summarizes findings of prior studies about equity and bikesharing. First, a prior study from the Transportation Research and Education Center (TREC) about the equity of bikesharing systems indicated that only $23 \%$ of the bikesharing systems $(n=53)$ have an equity statement or policy, while $7 \%$ are planning to introduce an equity statement or policy (Howland et al., 2017). The results of this study also revealed that equity influenced different aspects of bikesharing planning and operations, such as station siting decisions, fare structure and/or payment systems, and promotion, outreach, and marketing. Moreover, the surveyed bikeshare systems indicated that funding is the biggest barrier to address equity (Howland et al., 2017). 
Another study from the Transportation Research and Education Center (TREC) did a national scan of bikeshare equity programs (McNeil et al., 2019). In this study, the researchers explored 103 bikeshare equity programs from about 70 cities nationwide. The authors concluded that more than half of the equity programs targeted low-income populations, while only $16 \%$ of the programs targeted unbanked populations, people without smartphones or credit cards, and veterans or students (McNeil et al., 2019).

Some dockless bikesharing operators are exploring different ways to improve the equity of their systems by offering different methods to incorporate unbanked populations and people without smartphones or credit cards. In August 2017, Lime announced a pilot in Seattle, Washington that allows users of their dockless bikeshare system to use cash to load credit in their accounts and then call a specific number to unlock a dockless bike (LimeBike, 2017). In August 2018, Lime announced a partnership with PayNearMe that allows low-income qualified users to load 100 rides to their Lime accounts for just $\$ 5$ at cash in any PayNearMe locations (Eby, 2018).

Similar to Lime, Spin took some actions to improve equitable access to bikeshare. In August 2017, Spin announced their Spin Access program in Seattle, Washington. Spin Access allows users without smartphone or credit cards to use Spin dockless bikes. Users have to buy Spin Access cards using cash at specific locations and then use text messages to unlock bikes. This program also offered a $50 \%$ discount for qualified users in Seattle, Washington (Spin, 2017).

These proposed solutions implemented by Lime and Spin are aligned with some of the policy opportunities proposed by Shaheen et al. (2017) in a study about the equity of shared mobility. This study discussed the spatial, temporal, economic, physiological, and social barriers of shared mobility (Shaheen et al., 2017). The authors proposed potential policy options, such as installing shared mobility access kiosks and using other access modes that do not require smartphones, like text messages (Shaheen et al., 2017).

\subsection{SUMMARY}

Several transit agencies are considering adopting new payment technologies that can benefit both transit riders and transit agencies. However, this transition comes with new challenges for riders and agencies, particularly regarding equity. This review discussed some potential obstacles for the transition to cashless transit payment. Three potential equity-related issues were identified, which were access to banking accounts and credit/debit cards, access to smartphones, and potential pushbacks from local jurisdictions. A review of nationwide and transit agencies statistics suggests that the groups that are more likely to be affected by the transition to cashless fare payment systems are seniors, those with lower income levels, those with lower education levels, and minorities. Finally, this review briefly highlighted similar equity challenges and potential solutions from other modes like bikesharing, which are important considerations for transit agencies as they explore first mile/last mile partnerships. 


\section{ANALYSIS OF PAYMENT BEHAVIOR AND POTENTIAL FOR EXCLUSION}

One of this project's main goals is to define which riders are most at risk of being excluded as agencies transition to automated payment systems. This section presents results from Task 2 of the project exploring current payment behaviors, which we use to define which riders are most at risk of exclusion and to understand how they would pay transit fares if cash payment options were reduced or eliminated. To address these questions, we divided the field research into two phrases. First, we engaged transit users in Gresham-Portland and Eugene about their experiences with emerging technologies through focus group discussions. Second, we conducted a larger sample survey in all three cities (more than 2300 surveys in total) to examine to prevalence of barriers to cash-less technologies among existing transit riders. In both phases, we aimed to identify transit users most at risk of being excluded, and how strategies could mitigate or overcome those barriers. In the following sections, we first present methods and results for the focus groups and intercept surveys. We also explore several statistical models to uncover relationships between variables predicting exclusion, and conclude with implications for our research questions.

We conducted both phases of research-focus groups and transit rider intercept surveys-across three regions: Portland-Gresham, OR; Eugene, OR; and Denver, CO. Table 3.1 shows basic transit operating parameters from the three regions.

Table 3.1: Basic operating dimensions of case study regions

\begin{tabular}{|c|c|c|}
\hline $\begin{array}{l}\text { Lane County Transit } \\
\text { District (Eugene, } \\
\text { Oregon) }\end{array}$ & $\begin{array}{l}\text { Denver Regional } \\
\text { Transportation } \\
\text { District }\end{array}$ & $\begin{array}{l}\text { Tri-County Metro } \\
\text { Transportation } \\
\text { (TriMet) (Portland- } \\
\text { Gresham, Oregon) }\end{array}$ \\
\hline
\end{tabular}

\begin{tabular}{llll}
\hline Urbanized Area Population & 247,421 & $2,374,203$ & $1,849,898$ \\
\hline Service district population & 302,200 & $2,920,000$ & $1,551,531$ \\
\hline $\begin{array}{l}\text { Annual Boardings } \\
\text { (Unlinked) (M/year) }\end{array}$ & 10.7 & 104.8 & 97 \\
\hline $\begin{array}{l}\text { Vehicles Operated in Max } \\
\text { Service }\end{array}$ & Bus-89, BRT-18 & Bus-1043, LRT-172 & Bus-670, LRT-145 \\
\hline
\end{tabular}

(Source: 2018 National Transit Database)

For a general overview of the geographic extent and coverage of the transit systems, we include maps for each of the case cities. Figures 3.1, 3.2 and 3.3 show the maps for Porltand-Gresham, Eugene, and Denver, respectively. 


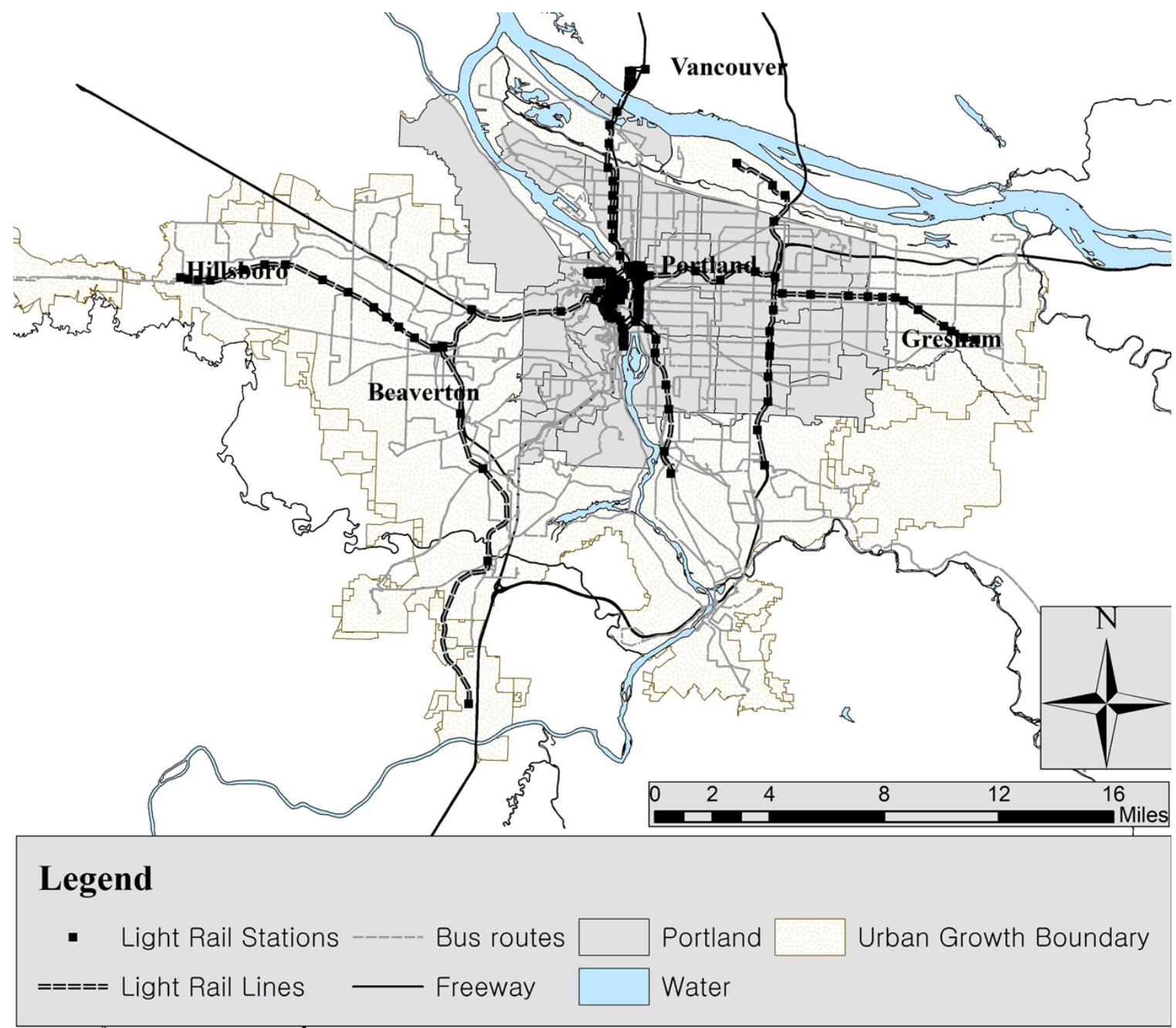

Figure 3.1: Map of Portland-Gresham transit coverage 


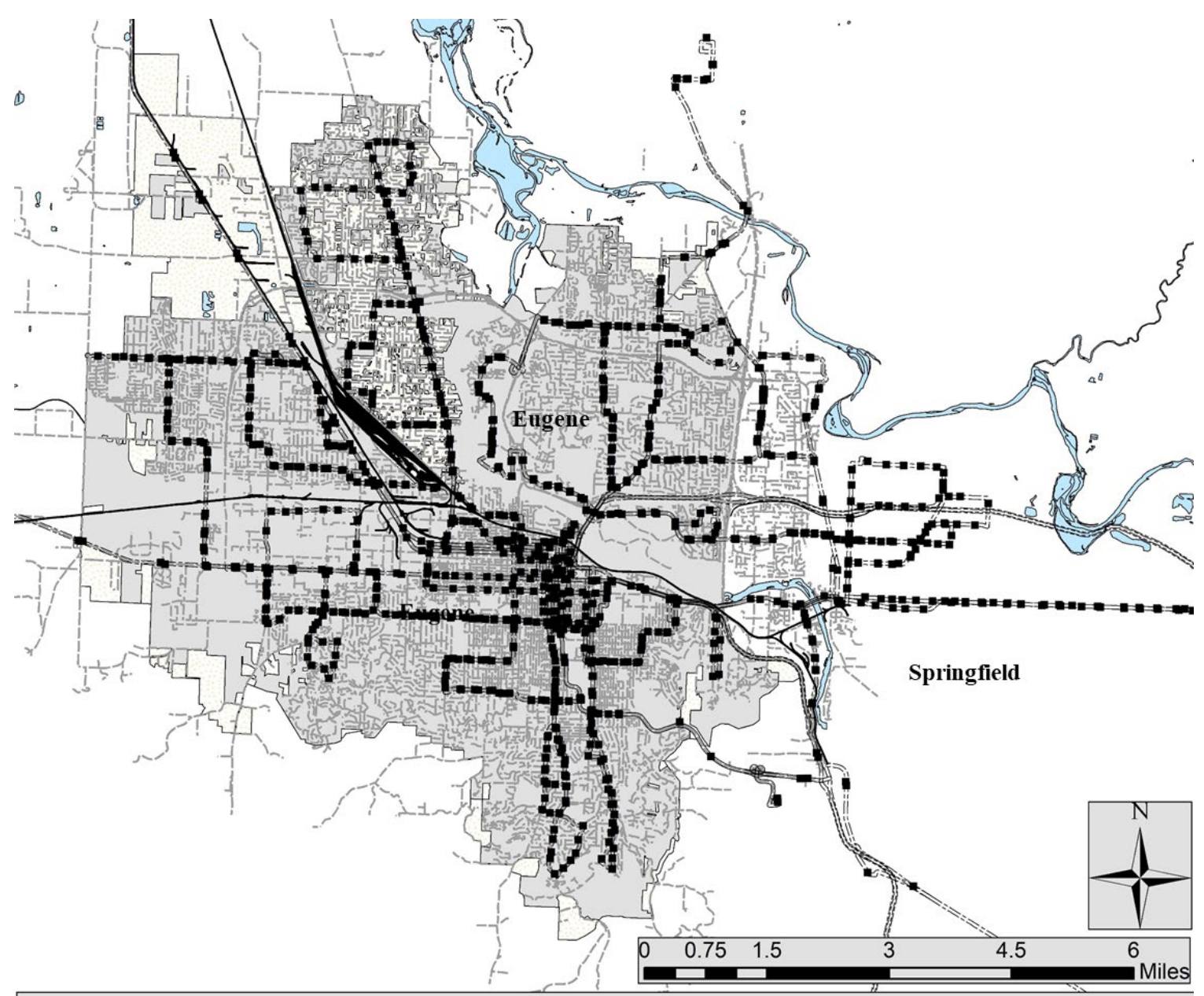

\section{Legend}

- LTD Stops - Railroad Routes $\square$ Eugene $\square$ Urban Growth Boundary
$=:=:=:=$ LTD Routes ------ Streets $\quad$ water

Figure 3.2: Map of Eugene, Oregon transit coverage 


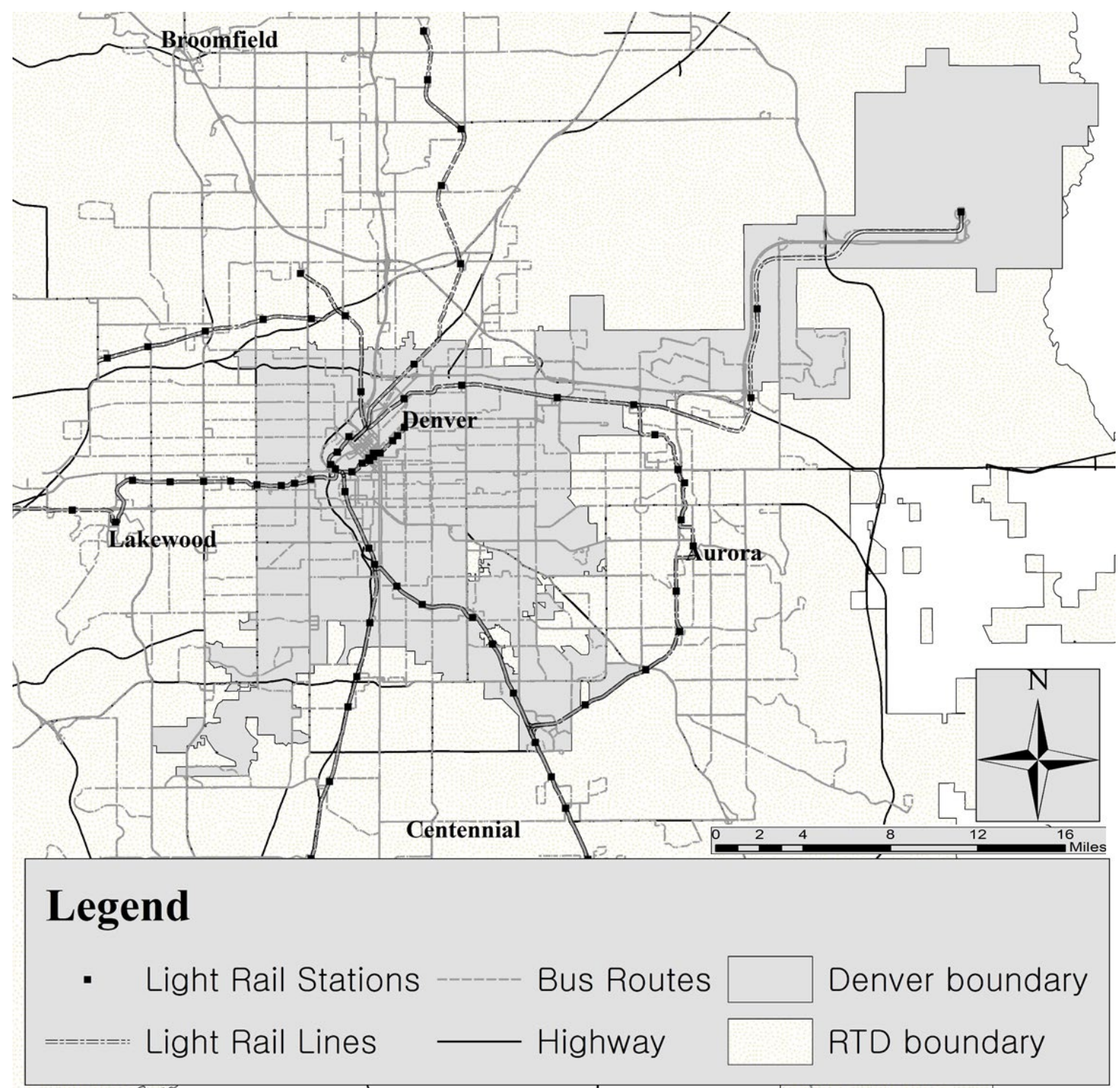

Figure 3.3: Map of Denver, Colorado transit coverage

\subsection{FOCUS GROUPS}

Focus group discussions were designed to explore nuanced barriers to using automated payment systems often difficult to understand from larger sample data. The team conducted three focus groups (two in Portland-Gresham and one in Eugene) with groups of 10-12 residents who regularly or occasionally use transit. We designed our focus groups to cover several important dimensions of technology access and transportation challenges: age, income and English language proficiency. The two Portland-Gresham area discussions included older transit riders and riders with limited English proficiency. The Eugene focus group was mainly lower-income transit dependent riders. (Our team had limited time available for our Denver rider survey work and so did not conduct a focus group there.) The discussions were held in June, July and August 2019; each lasted approximately 1 hour and were conducted in English, 
Spanish and Nepali. Participants were compensated with $\$ 25$ gift cards. A discussion guide used to administer the focus group can be found in Appendix 1.

\subsection{Focus Group Results}

After detailed note taking during the meetings, our team analyzed discussion content for distinct themes in order to identify key concerns. Some general lessons from the discussions are presented here according to those themes.

\subsubsection{Cash}

Most discussants were concerned about losing cash payment options, even if they did not regularly use it. There was a general sense of unease as participants often viewed cash as a good backup in case their phone or other payment technologies are not working. This reflected in general suspicion about the reliability of new fare payment options. Some worried about what would happen if card readers would lose power, or if their phones' batteries died.

Many participants seemed to agree that taking cash off buses would be a major impediment to using the bus for either themselves or others in the community, or perhaps tourists who would not know about retail payment options. Others claimed they would just go to a retail outlet to use cash if they needed to.

People remarked that not enough TVMs were present throughout the transit network and reported additional issues with using those fare machines such as broken credit card readers. People worried that they would have to pay more to use a cashless system because they would have to pay for a trip to a TVM in order to load cash onto their cards.

Of particular concern were those who reported scrounging, panhandling, or recycling bottles/cans for cash to pay for bus fare. Participants suggested that an optimal place to load cash fare onto cards would be outside of recycling centers.

People reflected that cash allowed for spur of the moment travel and some felt that requiring people to first load cash onto a fare card (particularly those who pay for one transit fare at a time) could create confusion or lead people to miss their bus. Many rely on buses in low density areas, and so payment locations may be far. One person claimed they use cash as a backup in case their card balance is low. Others worried that the added layer of complexity and stress could trigger mental health breakdowns. One person was upset that the economy in general was moving away from cash, which they felt was a more responsible medium compared to credit cards, and that using cash assisted with budgeting.

\subsubsection{Contactless Card Technology}

Discussion groups held in Portland-Gresham focused on the operation of the existing HOP smartcards. Interestingly, there were varied understandings of how the cards work and different methods used to load value on their cards. Some load value over the 
phone with a credit card and several use the TriMet office. None of our participants load their cards on a computer or phone. A couple of them have "honored citizen" cards, which allows low-income riders, seniors aged 65+, those with mental or physical disability, and Medicare recipients to travel at reduced fare. One participant reloaded their card with cash and TVMs because they feared the machines would damage their credit card. Interestingly, we found a significant group of participants did not understand how fare capping works, thinking that each card tap is a separate charge (and several specifically avoided travel because of the misunderstanding).

The contactless card technology discussion was different in Eugene, where smartcards were not in use at the time. Some discussions reflected this absence, such as concerns about card price and worry about being profiled through the card's location data. Yet many themes were consistent with conversations in Portland-Gresham: similar to other anxieties about new technologies, some worried that fare machines would run out of contactless cards and were unfamiliar with being able to load and store fare on cards.

\subsubsection{Data Tracking and Anonymity}

People expressed widespread distrust of new technologies and the potential to track individual habits or travel patterns with electronic cards instead of cash. Several people say they do not trust private information on their smartphone, and fear it could be hacked or somehow leaked while in use or through the agency's system. Similarly, some participants were unsure whether agencies could securely store collected payment data.

\subsubsection{Card Theft/Confiscation}

Multiple people reported either having had their transit card taken away or having heard of transit cards being taken away by bus operators during a dispute over balances (we could not substantiate specific stories, but this seems remotely possible). They also reported issues with transit pass/card theft, particularly those living in supportive or group housing environments or shelters. People seemed to view transit cards as more susceptible to theft than cash.

\subsubsection{Language and Tourism}

Some felt that cash was universally understood and more accessible to newcomers or visitors coming to town for events (especially large track and field events in Eugene). They felt that removing the cash option would undermine these people's ability to use transit.

\subsubsection{Technology}

Most focus group participants had access to a smartphone, though several had data limitations because they use prepaid accounts with either severely restricted data quotas or no cell data at all (we were not even aware this was an option). Others used cell service but did not connect their phones to the Internet at all and only use the core features like the phone, texting, and camera. Some do not use public Wi-Fi because of 
fear of hacking or viruses. About half of the focus group participants had Internet at home, but some had canceled it in exchange for using their phones and cell data.

Some participants, particularly older adults, reported that they struggle with using computers. Another reported that technology access could be fleeting; they have access to technology now, but just lost their job and so do not know about their access in the future. Some participants feared that their phones could lose battery when they are trying to travel and some are not comfortable with downloading new applications onto the phone. Others noted that they could receive free smartphones from social service organizations but that these phones were relatively useless due to limited data and poor cell service. Finally, some participants reported not having a credit card, so there would be no way to load fare without cash.

\subsection{INTERCEPT SURVEYS}

Focus group insights influenced our larger sample intercept survey. The intercept survey aimed to capture a more systematic understanding of challenges faced by a representative sample of transit riders in the three regions. Survey questions included current fare payment methods, travel behavior, and technology access. Demographic information was also collected in order to perform an equity analysis. A copy of the survey instrument can be found in Appendix 2.

The research team carried out intercept surveys in Portland, Gresham, Eugene and Denver in July, August and September of 2019. In total, 2,303 riders completed intercept surveys across the three regions. Our surveys were designed to take place during short "intercept" interviews between the research staff and the rider, typically at transit stations and bus stops. The surveys focus on current fare payment behavior, access to banking, Internet and smartphone resources, and potential fare payment behavior in the absence of cash options.

\subsubsection{The survey sample}

A summary of the demographic breakdown of the survey respondents is shown in Table 3.2. A "composite" sample of riders was created by weighting responses from the regions by their respective transit system's annual boardings. While these cities clearly do not cover the range of types of transit properties operating across the country, they do include a smaller and medium-sized metro area along with a small town (Eugene); as a result, we believe the composite profile may be useful as a rough proxy for many regions throughout the country.

Using survey data, we created categorical age, race/ethnicity and income groups to create simpler comparison groups with sufficient sample size. Millennials are those under 35 years old, Generation X is 35 to 55 and Boomers are those over 55. NonHispanic Whites (NHW) include those who selected white as their race and either selected "not Hispanic" or skipped the Hispanic question. Low-Income includes riders with incomes below $\$ 50,000$ per year. Many survey respondents declined to answer some of these demographic questions and are included as a missing category for comparison. 
Table 3.2: Demographic Breakdown of Survey Sample

\begin{tabular}{|c|c|c|c|c|}
\hline & Denver & Eugene & $\begin{array}{l}\text { Gresham/ } \\
\text { Portland }\end{array}$ & Composite \\
\hline $\mathrm{N}$ & 514 & 1240 & 549 & NA \\
\hline \multicolumn{5}{|l|}{ Race/Ethnicity group (share (\%)): } \\
\hline Missing & 10 & 11 & 17 & 13 \\
\hline NHW & 36 & 63 & 44 & 41 \\
\hline POC & 54 & 26 & 40 & 46 \\
\hline \multicolumn{5}{|l|}{ Age Group (share (\%)): } \\
\hline Boomer (Over 55 years) & 14 & 21 & 16 & 15 \\
\hline Generation X (35 to 55 years) & 26 & 25 & 26 & 26 \\
\hline Millennial (Under 35 years) & 46 & 40 & 41 & 43 \\
\hline Missing & 14 & 14 & 18 & 16 \\
\hline \multicolumn{5}{|l|}{ Income Group (share (\%)): } \\
\hline High Income & 19 & 7 & 15 & 17 \\
\hline Low Income & 44 & 60 & 43 & 44 \\
\hline Missing & 36 & 33 & 42 & 39 \\
\hline \multicolumn{5}{|l|}{ Income (share (\%)): } \\
\hline (blank) & 12 & 11 & 16 & 14 \\
\hline Less than $\$ 14,999$ & 17 & 29 & 19 & 18 \\
\hline$\$ 15,000$ to $\$ 24,999$ & 8 & 15 & 9 & 9 \\
\hline$\$ 25,000$ to $\$ 34,999$ & 9 & 8 & 8 & 8 \\
\hline$\$ 35,000$ to $\$ 49,999$ & 11 & 8 & 7 & 9 \\
\hline$\$ 50,000$ to $\$ 74,999$ & 6 & 4 & 7 & 6 \\
\hline$\$ 75,000$ to $\$ 99,999$ & 5 & 1 & 3 & 4 \\
\hline$\$ 100,000$ to $\$ 149,999$ & 4 & 1 & 3 & 4 \\
\hline$\$ 150,000$ or more & 3 & 1 & 2 & 2 \\
\hline Prefer not to say & 25 & 22 & 26 & 25 \\
\hline \multicolumn{5}{|l|}{ Gender (share (\%)): } \\
\hline (blank) & 8 & 7 & 12 & 10 \\
\hline Female & 35 & 45 & 37 & 36 \\
\hline Male & 56 & 45 & 48 & 52 \\
\hline Non-Binary / Third Gender & 0 & 2 & 1 & 1 \\
\hline Prefer not to say & 1 & 1 & 1 & 1 \\
\hline
\end{tabular}

In the following subsections, we present the results for questions pertaining to current fare payment, access to banking and Internet, phone data limitations, comfort using new payment practices, and future payment practices were cash not available. We present the results in four ways: 1) Overall results for the three regions and the composite ridership; 2) By city and income group; 3) By city and race/ethnicity; and 4) By city and age group. Chi-square statistical tests were used to confirm if differences between the groups (within a city, or within the composite group) were statistically different at a 0.05 level, indicated by bold-face numbers. 


\subsection{Survey results}

The overall results are shown in Table 3.3. Nearly $30 \%$ of composite transit riders currently pay for transit on board with cash. Cash use at ticket vending machines (TVMs) and retail outlets is also quite high (42\%), and significantly higher than for credit and debit use at those outlets (30\%).

Rates of smartphone, banking, and credit card access are similar to those of the general population (Pew 2019). While few people cite a complete lack of Internet connectivity $(6 \%)$, an alarming number $(29 \%)$ claim they rely solely on public Wi-Fi for Internet through their phone. A small but significant number (12\%) do not connect their phone to the Internet, and a larger number are concerned about reaching data limits on their phones. These data suggest substantial challenges even for those with smartphones, to reliably pay for transit via a smartphone.

A significant number of riders are "somewhat" or "completely" uncomfortable using many of the automated fare payment tools such as websites and smartphones. This corresponds to focus group discussions, in which many riders expressed discomfort storing financial information in websites or on their phones. Finally, for current riders who pay cash on board, we asked them what they might do if cash were eliminated. A small but significant share (22\%) claim they would not be able to ride at all, and the remaining claims they could move to either some of the other cash options $(41 \%)$ or to options using credit or debit payment (35\%).

Interesting differences also exist across the cities. Across the board, survey respondents from Eugene had lower access to Internet and banking resources, were less comfortable with automated fare payment approaches, and were more likely to rely on cash even after cash-on-board options were removed. The other two major metros were fairly similar on these issues. 
Table 3.3: Overall breakdown of survey results

\begin{tabular}{|c|c|c|c|c|}
\hline & Denver & Eugene & $\begin{array}{l}\text { Gresham/ } \\
\text { Portland }\end{array}$ & Composite \\
\hline $\mathrm{N}$ & 514 & 1240 & 549 & \\
\hline \multicolumn{5}{|c|}{ Share (\%) of riders with current fare payment practice: } \\
\hline Employer provided & 27 & 35 & 16 & 22 \\
\hline Social service provider & 6 & 0 & 8 & 7 \\
\hline Cash on bus & 33 & 29 & 24 & 29 \\
\hline Cash at TVMs & 29 & 19 & 25 & 27 \\
\hline Cash at retail/agency & 19 & 15 & 13 & 16 \\
\hline Apple/Android Pay & NA & NA & 6 & 6 \\
\hline Credit/debit at TVM & 21 & 10 & 15 & 18 \\
\hline Smartphone app & 23 & 5 & 31 & 26 \\
\hline Credit/debit at retail/agency & 13 & 14 & 11 & 12 \\
\hline \multicolumn{5}{|c|}{ Share (\%) of riders lacking access to banking and internet: } \\
\hline $\begin{array}{l}\text { Unbanked (No savings, checking, } \\
\text { credit, debit accounts) }\end{array}$ & 6 & 4 & 9 & 7 \\
\hline Lacks smartphone & 12 & 19 & 14 & 13 \\
\hline No Internet & 6 & 8 & 6 & 6 \\
\hline Only Wi-Fi for internet & 28 & 38 & 28 & 29 \\
\hline \multicolumn{5}{|c|}{ Share (\%) of riders experiencing phone data limitations: } \\
\hline No data use on phone & 11 & 14 & 13 & 12 \\
\hline $\begin{array}{l}\text { Somewhat or very concerned about } \\
\text { data limits }\end{array}$ & 19 & 26 & 21 & 20 \\
\hline \multicolumn{5}{|c|}{ Share (\%) of riders completely or somewhat uncomfortable using the following payment practices: } \\
\hline Website - One Time Payment & 26 & 30 & 21 & 24 \\
\hline $\begin{array}{l}\text { Website - Recurring payments } \\
\text { Smartphone - Recurring payments } \\
\text { Purchase by phone }\end{array}$ & $\begin{array}{l}36 \\
32 \\
\text { NA }\end{array}$ & $\begin{array}{l}45 \\
\text { NA } \\
49\end{array}$ & $\begin{array}{l}29 \\
25 \\
40\end{array}$ & $\begin{array}{l}33 \\
28 \\
40\end{array}$ \\
\hline
\end{tabular}

Share (\%) of current cash-on-board users who will switch to the following practices:

$\begin{array}{lllll}\text { Some form of Credit/Debit (Online, } & 33 & 36 & 39 & 35 \\ \text { Phone, etc.) } & & & 35 & 41 \\ \text { Some form of Cash (TVM, Retail, etc.) } & 43 & 63 & \mathbf{2 3} & 22 \\ \text { Unable to Ride } & 22 & 13 & \end{array}$

Notes: Bolded numbers show significant differences at the 0.05 level.

\subsection{Equity analysis by income}

Table 3.4 presents results broken down by income group, where "Low-Income" (Low) was those with incomes below 50,000 dollars per year, and High was those above that level, with separate results for this "missing" (Miss.) group. Focusing on the composite analysis, it is clear there are some differences in fare payment practices between the three income groups. The high income group overall is more likely to have employerprovided passes and to pay by credit or debit or smart phone app. They are also significantly less likely to pay using some form of cash. 
The composite analysis shows significantly lower access to banking and internet for low income respondents. For both high income and low income respondents, reliance on Wi-Fi for Internet was substantial and differences between income groups within each city followed closely these overall patterns. Interestingly, high income riders in Eugene had significantly lower access to smartphones than respondents in the other cities.

Riders concerned about phone data limits spanned the income groups fairly uniformly. At the same time, low income respondents were much more likely to not use data on their phones. In general, low income respondents were less comfortable using new payment systems than high income respondents, but this may be an age effect.

Finally, the analysis of payment behavior if cash-on-board options were eliminated showed that high income groups were more likely to move to some form of credit or debit based payment, while a higher share of low income groups claimed they would continue to use cash or be unable to ride at all. 
$1 \quad$ Table 3.4: Breakdown of survey results by income

\begin{tabular}{|c|c|c|c|c|c|c|c|c|c|c|c|c|}
\hline & \multicolumn{3}{|c|}{ Denver } & \multicolumn{3}{|c|}{ Eugene } & \multicolumn{3}{|c|}{ Gresham/Portland } & \multicolumn{3}{|c|}{ Composite } \\
\hline & High & Low & Miss. & High & Low & Miss. & High & Low & Miss. & High & Low & Miss. \\
\hline $\mathrm{N}$ & 99 & 228 & 187 & 89 & 743 & 408 & 82 & 234 & 233 & 17 & 44 & 39 \\
\hline \multicolumn{13}{|l|}{ Share of riders (\%) with current fare payment practice: } \\
\hline Employer provided & 35 & 24 & 26 & 27 & 37 & 34 & 29 & 14 & 13 & 33 & 21 & 20 \\
\hline Social service provider & 3 & 9 & 5 & 0 & 0 & 0 & 1 & 11 & 7 & 2 & 9 & 6 \\
\hline Cash on bus & 21 & 36 & 36 & 28 & 30 & 28 & 9 & 27 & 27 & 16 & 32 & 31 \\
\hline Cash at retail/agency & 12 & 23 & 18 & 17 & 17 & 12 & 7 & 17 & 12 & 10 & 20 & 15 \\
\hline Apple/Android Pay & NA & NA & NA & NA & NA & NA & 6 & 11 & 2 & 6 & 11 & 2 \\
\hline Credit/debit at TVM & 26 & 21 & 18 & 16 & 12 & 5 & 23 & 18 & 10 & 25 & 19 & 13 \\
\hline Smartphone app & 38 & 24 & 15 & 7 & 6 & 2 & 35 & 35 & 25 & 36 & 27 & 19 \\
\hline Credit/debit at retail/agency & 16 & 14 & 12 & 19 & 16 & 10 & 12 & 13 & 9 & 15 & 14 & 10 \\
\hline \multicolumn{13}{|c|}{ Share of riders (\%) lacking access to banking and internet: } \\
\hline Unbanked (No savings, checking, credit, debit & 0 & 9 & 7 & 0 & 3 & 6 & 4 & 6 & 13 & 1 & 7 & 10 \\
\hline Lackss smartphone & 5 & 14 & 14 & 16 & 17 & 24 & 2 & 15 & 17 & 4 & 14 & 16 \\
\hline No Internet & 1 & 6 & 10 & 1 & 7 & 11 & 2 & 5 & 8 & 2 & 6 & 9 \\
\hline Only Wi-Fi for internet & 19 & 35 & 26 & 26 & 41 & 35 & 16 & 29 & 31 & 18 & 32 & 29 \\
\hline \multicolumn{13}{|c|}{ Share of riders (\%) experiencing phone data limitations: } \\
\hline No data use on phone & 2 & 13 & 12 & 7 & 12 & 18 & 2 & 15 & 14 & 2 & 14 & 13 \\
\hline Somewhat or very concerned about data limits & 17 & 19 & 20 & 25 & 27 & 25 & 29 & 19 & 20 & 22 & 20 & 20 \\
\hline \multicolumn{13}{|c|}{ Share of riders (\%) completely or somewhat uncomfortable using the following payment practices: } \\
\hline Website - One Time Payment & 19 & 27 & 29 & 30 & 28 & 32 & 15 & 20 & 26 & 18 & 24 & 28 \\
\hline Website - Recurring payments & 33 & 36 & 38 & 44 & 48 & 42 & 20 & 27 & 33 & 28 & 33 & 36 \\
\hline Smartphone - Recurring payments & 29 & 31 & 34 & NA & NA & NA & 16 & 24 & 28 & 24 & 28 & 31 \\
\hline Purchase by phone & NA & NA & NA & 53 & 50 & 45 & 41 & 36 & 42 & 42 & 38 & 42 \\
\hline \multicolumn{13}{|c|}{ Share of current cash-on-board users (\%) who will switch to the following practices: } \\
\hline Some form of Credit/Debit (Online, Phone, etc.) & 62 & 34 & 24 & 28 & 42 & 26 & 43 & 37 & 40 & 57 & 36 & 31 \\
\hline Some form of Cash (TVM, Retail, etc.) & 29 & 40 & 50 & 80 & 62 & 61 & 29 & 40 & 31 & 31 & 41 & 42 \\
\hline
\end{tabular}

2 Notes: Bolded numbers are significant differences at 0.05 level. "High" is income above 50k/year, "Low" below 50k/year and "Miss." missing 3 income. 
$2 \quad 3.6$ Equity analysis by race and ethnicity

3 In this analysis, we break out responses into Non-Hispanic whites (NHW) and riders of

4 color (POC) (Table 3.5). NHW are those not Hispanic and selecting White for their race

5 (respondents who skipped the Hispanic question but selected White for their race were

6 also included in the NHW group). Riders of color are those answering Hispanic and/or

7 any racial category other than white. The "missing" group (13\% of total respondents)

8 declined to answer the race question.

The differences between groups here are less stark than those between income groups,

11 which corroborates some of the findings from other studies of digital/banking divide (e.g.

12 Apaam, 2018; Pew, 2019). Riders of color are more likely to pay with cash both on

13 board and at TVMs. Otherwise, the differences are fairly small or statistically

14 insignificant. Indeed, riders of color have slightly higher (though statistically insignificant)

15 access to smartphones and Internet. Levels of discomfort using automated fare

16 payment systems is nearly identical between the two rider groups and future payment

17 differences were not statistically significant. There were equity issues by race/ethnicity

18 across cities that often differed from each other. 
1 Table 3.5: Breakdown of survey results by race/ethnicity

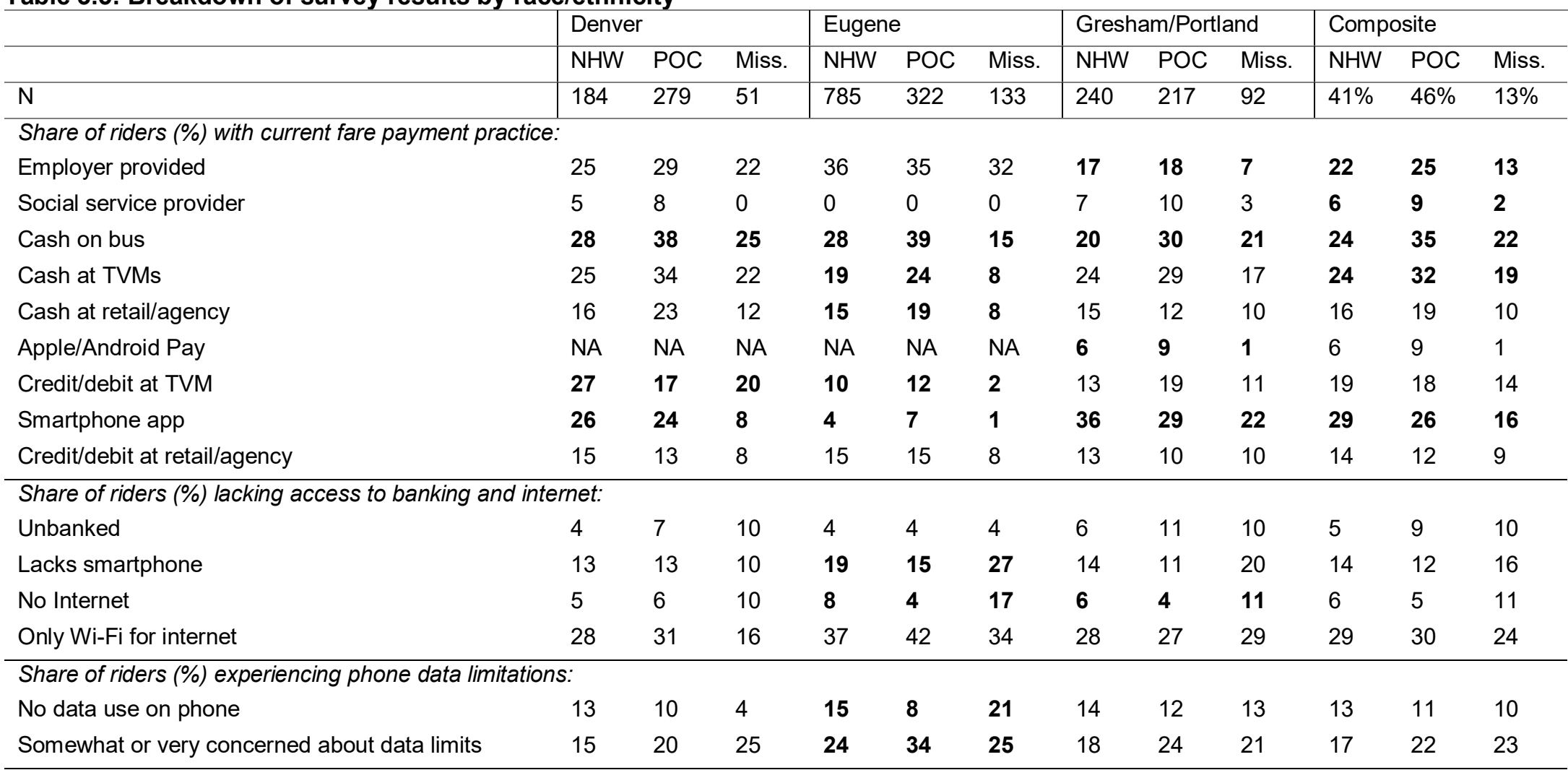

\begin{tabular}{|c|c|c|c|c|c|c|c|c|c|c|c|c|}
\hline \multicolumn{13}{|c|}{ Share of riders (\%) completely or somewhat uncomfortable using the following payment practices: } \\
\hline Website - One Time Payment & 26 & 26 & 29 & 31 & 25 & 33 & 20 & 22 & 24 & 24 & 24 & 26 \\
\hline Website - Recurring payments & 38 & 36 & 35 & 47 & 41 & 47 & 28 & 28 & 32 & 34 & 33 & 34 \\
\hline Smartphone - Recurring payments & 34 & 30 & 35 & NA & NA & NA & 24 & 25 & 26 & 28 & 28 & 30 \\
\hline Purchase by phone & NA & NA & NA & 51 & 44 & 50 & 39 & 40 & 39 & 41 & 40 & 40 \\
\hline \multicolumn{13}{|c|}{ Share of current cash-on-board users (\%) who will switch to the following practices: } \\
\hline Some form of Credit/Debit (Online, Phone, etc.) & 47 & 26 & 38 & 39 & 32 & 20 & 34 & 48 & 16 & 41 & 34 & 26 \\
\hline Some form of Cash (TVM, Retail, etc.) & 33 & 50 & 23 & 64 & 67 & 30 & 40 & 32 & 32 & 39 & 44 & 28 \\
\hline Unable to Ride & 20 & 23 & 15 & 11 & 15 & 25 & 26 & 20 & 26 & 21 & 22 & 22 \\
\hline
\end{tabular}

2 Notes: Bolded numbers show significant differences at the 0.05 level. NHW $=$ Non-Hispanic whites, POC = Riders of Color, "Miss" declined to 3 answer. 


\section{$1 \quad 3.7$ Equity analysis by age}

2 In this analysis, we break out responses into three groups by age: Millennials are those

3 under 35 years old, Generation X are 35 to 55 and Boomers are those over 55, along

4 with a "missing" category. Results for an analysis by age group is shown in Table 3.6.

5 Millennials were both more likely to pay with cash but also more likely to pay with 6 smartphone applications (though not statistically significantly), while being much less

7 likely to use retail, compared to the two other age groups. Conversely, Boomer

8 respondents were much more likely to use the two retail options and much less likely to

9 use smartphone applications. Generation X respondents were typically between the two

10 groups. The three groups were identical in access to banking and credit resources

11 (other than the missing group). Almost one third of Boomer respondents lack access to

12 a smartphone, significantly more than the other groups. Similarly, the older group had

13 significantly less access to the Internet but was also was less likely to use data on their

14 phones and was less concerned about reaching phone data limits. The older group was

15 across the board less comfortable using automated payment systems, though all groups

16 were uncomfortable purchasing by phone. Finally, older respondents claimed they

17 would remain more reliant on cash and be more likely unable to ride if cash-on-board

18 payment options were eliminated. 


\begin{tabular}{|c|c|c|c|c|c|c|c|c|c|c|c|c|c|c|c|c|}
\hline & \multicolumn{4}{|l|}{ Denver } & \multicolumn{4}{|c|}{ Eugene } & \multicolumn{4}{|c|}{ Gresham/Portland } & \multicolumn{4}{|c|}{ Composite } \\
\hline & Boom & $\begin{array}{l}\text { Gen } \\
X\end{array}$ & Mill & Miss & $\begin{array}{l}\text { Boo } \\
\mathrm{m}\end{array}$ & $\begin{array}{l}\text { Gen } \\
X\end{array}$ & Mill & Miss & $\begin{array}{l}\text { Boo } \\
\mathrm{m}\end{array}$ & $\begin{array}{l}\text { Gen } \\
X\end{array}$ & Mill & Miss & $\begin{array}{l}\text { Boo } \\
m\end{array}$ & $\begin{array}{l}\text { Gen } \\
X\end{array}$ & Mill & Miss \\
\hline $\mathrm{N}$ & 73 & 132 & 237 & 72 & 263 & 315 & 492 & 170 & 86 & 140 & 225 & 98 & 15 & 26 & 43 & 16 \\
\hline \multicolumn{17}{|c|}{ Share of riders (\%) with current fare payment practice: } \\
\hline Employer provided & 19 & 20 & 33 & 26 & 44 & 24 & 40 & 28 & 12 & 21 & 17 & 10 & 17 & 21 & 26 & 18 \\
\hline Social service provider & 11 & 5 & 6 & 4 & 0 & 0 & 0 & 0 & 7 & 13 & 7 & 2 & 8 & 8 & 6 & 3 \\
\hline Cash on bus & 25 & 32 & 38 & 28 & 17 & 38 & 32 & 24 & 27 & 17 & 31 & 15 & 25 & 25 & 35 & 21 \\
\hline Cash at TVMs & 16 & 31 & 34 & 24 & 9 & 25 & 22 & 15 & 35 & 23 & 26 & 17 & 25 & 27 & 30 & 20 \\
\hline Cash at retail/agency & 25 & 21 & 16 & 19 & 16 & 21 & 13 & 10 & 28 & 19 & 6 & 9 & 26 & 20 & 11 & 14 \\
\hline Apple/Android Pay & NA & NA & NA & NA & NA & NA & NA & NA & 3 & 6 & 8 & 3 & 3 & 6 & 8 & 3 \\
\hline Credit/debit at TVM & 19 & 23 & 20 & 21 & 5 & 13 & 13 & 4 & 15 & 12 & 19 & 11 & 16 & 18 & 19 & 15 \\
\hline Smartphone app & 10 & 26 & 30 & 13 & 5 & 4 & 5 & 4 & 21 & 25 & 43 & 20 & 15 & 24 & 34 & 16 \\
\hline Credit/debit at retail/agency & 14 & 17 & 12 & 11 & 17 & 17 & 12 & 9 & 26 & 19 & 2 & 9 & 20 & 18 & 8 & 10 \\
\hline \multicolumn{17}{|c|}{ Share of riders (\%) lacking access to banking and internet: } \\
\hline Unbanked & 7 & 7 & 5 & 10 & 2 & 5 & 3 & 4 & 5 & 8 & 10 & 10 & 5 & 7 & 7 & 10 \\
\hline Lacks smartphone & 41 & 8 & 5 & 17 & 40 & 18 & 6 & 25 & 37 & 11 & 5 & 17 & 39 & 10 & 5 & 17 \\
\hline No Internet & 22 & 4 & 1 & 13 & 19 & 7 & 2 & 10 & 16 & 2 & 1 & 12 & 19 & 3 & 1 & 12 \\
\hline Only Wi-Fi for internet & 26 & 36 & 27 & 22 & 28 & 43 & 40 & 39 & 30 & 30 & 26 & 27 & 28 & 34 & 27 & 25 \\
\hline \multicolumn{17}{|c|}{ Share of riders (\%) experiencing phone data limitations: } \\
\hline No data use on phone & 38 & 8 & 4 & 8 & 32 & 13 & 4 & 15 & 33 & 10 & 7 & 12 & 35 & 9 & 5 & 11 \\
\hline $\begin{array}{l}\text { Somewhat or very concerned abt. data } \\
\text { limits }\end{array}$ & 7 & 20 & 21 & 24 & 16 & 30 & 30 & 26 & 21 & 19 & 24 & 19 & 14 & 20 & 22 & 22 \\
\hline \multicolumn{17}{|c|}{ Share of riders (\%) completely or somewhat uncomfortable using the following payment practices: } \\
\hline Website - One Time Payment & 42 & 25 & 23 & 22 & 40 & 35 & 19 & 35 & 35 & 24 & 14 & 22 & 39 & 25 & 19 & 23 \\
\hline Website - Recurring payments & 52 & 36 & 35 & 28 & 51 & 51 & 39 & 44 & 40 & 34 & 19 & 34 & 46 & 36 & 28 & 32 \\
\hline Smartphone - Recurring payments & 47 & 32 & 28 & 28 & NA & NA & NA & NA & 35 & 28 & 16 & 30 & 41 & 30 & 23 & 29 \\
\hline Purchase by phone & NA & NA & NA & NA & 56 & 52 & 44 & 46 & 43 & 45 & 36 & 37 & 45 & 46 & 37 & 37 \\
\hline \multicolumn{17}{|c|}{ Share of current cash-on-board users (\%) who will switch to the following practices: } \\
\hline $\begin{array}{l}\text { Some form Credit/Debit (Online, Phone, } \\
\text { etc) }\end{array}$ & 39 & 38 & 32 & 25 & 35 & 33 & 42 & 22 & 13 & 38 & 53 & 13 & 26 & 38 & 40 & 20 \\
\hline Some form of Cash (TVM, Retail, etc.) & 44 & 43 & 43 & 40 & 72 & 66 & 60 & 56 & 52 & 42 & 27 & 33 & 50 & 44 & 38 & 38 \\
\hline Unable to Ride & 17 & 19 & 24 & 20 & 9 & 14 & 15 & 12 & 35 & 21 & 20 & 20 & 25 & 19 & 22 & 20 \\
\hline
\end{tabular}

2 Notes: Bolded numbers show significant differences at the 0.05 level. 


\subsection{FACTORS PREDICTING CASH-ON-BOARD USE}

Alongside tabulations of survey responses presented in the previous sections, we can also use modeling techniques to understand the relative contribution of different factors to predicting someone's use of cash-on-board payment. We focus on cash-on-board as it is likely the first place where cash payment would be eliminated, and it is those riders which would experience the greatest inconvenience and disruption.

\subsubsection{Binary regression}

A series of binary regression models were run to predict cash-on-board payment, versus all other payment types. Models included various combinations of demographic and digital and banking access and other survey response variables. Generally, candidate models' goodness of fits were disappointingly low as missing variables in some of the responses, especially age, income and race/ethnicity plagued the models. Table 3.7 presents results from one of the better models and shows that access to credit cards and comfort with automated payment systems significantly reduce the use of cash-on-board, while higher incomes, better phone data plans and higher frequency of ridership also predicted lower cash-on-board payment. Interestingly, age, smartphone access and race/ethnicity to not seem to correlate with cash-on-board use.

Table 3.7: Binary regression to predict current payment using cash-on-board

\begin{tabular}{|c|c|c|c|c|c|}
\hline Variable & Beta & S.E. & Wald & $\mathrm{df}$ & Sig. \\
\hline Rides per month & -.032 & .018 & 3.125 & 1 & $.077^{*}$ \\
\hline Smartphone ownership (Y/N) & -.081 & .445 & .034 & 1 & .855 \\
\hline Phone data limits not a concern (Y/N) & -.382 & .231 & 2.735 & 1 & $.098^{*}$ \\
\hline Only use public Wi-Fi (Y/N) & .210 & .247 & .721 & 1 & .396 \\
\hline Credit card access $(\mathrm{Y} / \mathrm{N})$ & -.911 & .235 & $\begin{array}{l}14.98 \\
8 \\
\end{array}$ & 1 & $.000^{* * *}$ \\
\hline $\begin{array}{l}\text { Avg comfort with online/phone payment score } \\
\text { (Scale of } 1-4, \text { with } 4 \text { being highest comfort) }\end{array}$ & -.262 & .102 & 6.603 & 1 & $.010^{* * *}$ \\
\hline Age & -.004 & .008 & .182 & 1 & .669 \\
\hline Income & -.006 & .003 & 3.875 & 1 & $.049^{* *}$ \\
\hline Non-Hispanic White $(\mathrm{Y} / \mathrm{N})$ & -.287 & .229 & 1.568 & 1 & .210 \\
\hline Constant & 1.582 & .751 & 4.435 & 1 & $.035^{\star *}$ \\
\hline
\end{tabular}

\subsubsection{Factor analysis}

We undertook an additional "Factor" analysis to augment the weak regression modeling results. Factor analysis reveals patterns in the data and enables researchers to distill datasets with a large number of variables into a few "types" based on strong relationships among the variables. In this case, we can reduce the large number of survey responses representing each rider into several rider "types" using this technique. By analyzing a variety of variables alongside our cash-on-board payment, we could understand which variables were commonly correlated with cash-on-board payment 
behavior. The analysis revealed four significantly common rider types among those surveyed (accounting for $56.2 \%$ of the total variance in the data). The results of the analysis are shown in Table 3.8, where significant relationships (absolute value of correlation scores higher than 0.3 ) are highlighted in the bolded numbers.

The first rider type revealed was older than average and more likely non-Hispanic white, but this was not correlated with payment type. The second rider type revealed did not ride very much and was higher than average income and had good access to Internet. This second rider type did not correlate with payment behavior. The third rider type had good access to credit cards and high comfort using automated payment systems and had lower than average likelihood of using cash-on-board payment systems. This rider type corroborates the findings of the regression analysis. The fourth rider type had high access to smartphone and good phone data plans, but this did not correlate with any particular payment behavior.

Table 3.8: Component Score Coefficient Matrix.

\begin{tabular}{l|l|l|l|l}
\hline & 1 & 2 & 3 & 4 \\
\hline Rides per month & -.027 & -.610 & .227 & .058 \\
\hline Smartphone ownership (Y/N) & -.184 & .168 & -.143 & .561 \\
\hline Only use public Wi-Fi (Y/N) & .223 & -.328 & -.198 & .189 \\
\hline Credit card access (Y/N) & .122 & .183 & .308 & .021 \\
\hline Ave comfort with online/phone payment score (Scale of & -.225 & -.009 & .475 & -.121 \\
1-4, with 4 being highest comfort) & & & & \\
\hline Age & .545 & -.055 & -.008 & -.118 \\
\hline Income & .176 & .321 & .059 & .178 \\
\hline Non-Hispanic White (Y/N) & .440 & .071 & -.011 & .085 \\
\hline Phone data limits not a concern (Y/N) & .128 & -.215 & -.004 & .611 \\
\hline Cash on board payment (always or often) (Y/N) & -.122 & .223 & -.581 & .018
\end{tabular}

\subsection{DISCUSSION}

Overall, results from this study show that transit riders are similarly resourced to the general population (Apaam, 2018; Pew, 2019), and in some ways even better equipped for automated payment systems. Still, our investigation reveals some significant barriers and disparities among current transit riders. Several important conclusions and concerns emanate from the results and analysis presented here:

- A significant number of riders ( $30 \%)$ still rely heavily on paying cash onboard buses.

- Those who currently pay cash on-board appeared able to switch to other cash and non-cash options, though a significant number imagine they will continue to rely only on cash, while a small number claim they would not be able to ride any longer.

- Overall, smartphone ownership is high (over $80 \%$ ) for all groups, other than Boomers 
- A small but significant number ( 20\%) are concerned about reaching phone data limits.

- A significant number ( $30 \%)$ depend on nontraditional sources for phone data such as public Wi-Fi for Internet connectivity.

- There is general unease with using automated payment systems requiring credit information to be stored or input into websites or phones.

- High income respondents typically had higher access to smartphones, Internet connectivity, and financial services, and modeling showed higher incomes predicted a lower likelihood to pay cash-on-board controlling for other factors

- Older respondents had significantly lower access to smartphones and Internet connectivity.

- Modeling revealed that access to credit cards and comfort using automated payment systems predicted lower reliance on cash-on-board payment

Interestingly, some of these disparities differed slightly from city to city, though systematic differences were unclear. A significant takeaway is that local conditions and patterns will differ substantially from national averages and therefore authors recommend doing local survey work to understand particular rider issues with these transitions.

Based on these general results, it seems that outreach, education and training will be an important element of improving adaptation to new fare payment systems, since many of our respondents were concerned about apps, privacy and using their phones for these kinds of transactions. The modeling revealed that credit card access and greater comfort using emerging automated payment systems (either on-line or through a smartphone) significantly predicted lower cash-on-board use, controlling for other factors such as income, smartphone access, frequency of use and other factors. While public agencies may have difficulty improving access to credit cards, improving understanding and comfort using payment systems seems achievable through expanded outreach, partnerships with community organizations, and training programs.

Modeling showed that concern over phone data limits moderately predicted cash-onboard payment, controlling for other factors, and so free public Wi-Fi near or on transit could also offer an important improvement for those who are dependent on Wi-Fi hotspots, especially those who may be far from stores, libraries or cafes which offer such services. ${ }^{2}$ Finally, for older adults, a smartphone program and training may be needed to close the gap in smartphone access and use and proficiency, especially if they are going to be using transit more as they phase out of driving themselves as they age. It seems that cash acceptance through retail networks or on TVMs may still be necessary for the medium term as a large share of users insist they plan to use cash even if not on board.

2 Some agencies have experimented with providing this service, such as LA Metro. https://thesource.metro.net/2017/06/15/pilot-program-begins-to-put-wifi-on-150-metro-buses/ 


\section{COST BENEFIT FRAMEWORK}

In this task we develop a cost-benefit framework to evaluate fare collection systems, and programs and investments made to accommodate cash users. The framework combines both users and agency approaches to understanding the impacts and differences between different fare payment systems. The qualitative user framework focuses on convenience and dimensions of social inequality. The quantitative agency framework incorporates fixed costs of installation and capital, and recurring costs of maintenance and operations along with other issues such as interagency or third-party agreements which could affect the ongoing operations of some mitigation programs. Before we developed the framework, we did a national scan of agency practice with respect to fare automation and equity mitigations and collected cost data from several experts in the area. TAC members also assisted with feedback on agency costs and practices which were used in our framework.

\subsection{AGENCY PRACTICE REVIEW}

To help the team to develop a cost benefit framework and support our case study preparation in the next task we first reached out to agencies and organizations across the country to understand mitigation practices geared to assist cash users in transitioning to automated fare systems. We reached out to over 50 contacts at different types of organizations, and a list of these contacts is found in Appendix 3.

We asked each agency the following questions by email (but offered to reach out to them by phone if they prefer):

1. In what ways has your agency modernized fare payment and technology systems in the past 5 years? Are you transitioning to "cashless" fare payment systems? Over what time frame are any transitions occurring?

2. How has your agency evaluated the equity implications (perhaps through a Title VI analysis) of modernized fare payment and technology systems?

3. What policies, programs, or projects has your agency deployed to mitigate the impacts of automated payment fare systems on customers that live or work in transit deficient areas (e.g. far from ticket vending machines); un- or underbanked customers; customers without readily available internet access; customers who do not own smartphones or have low technological literacy; customers with limited English proficiency; and others potentially excluded from automated payment fare systems?

4. What are the costs associated with your agency's equity mitigation strategies?

5. What else about your riders would you want to know to better understand these issues?

While we only received responses from 10 agencies, the feedback nonetheless provides some interesting results. These responses enabled us to design our example fare collection scenarios for testing in the case studies. 


\subsection{COST EFFECTIVENESS FRAMEWORK}

\subsubsection{Overview}

A final set of research questions for this project relate to the effect and costs of mitigation efforts to reduce rider exclusion across cash-based and cash-less fare scenarios: 1) how effective are proposed mitigations at including potentially excluded riders, 2) how costly are these mitigations, and 3) therefore, how cost-effective are they? To answer these questions we developed a cost-benefit Excel model integrating a qualitative assessment of equity impacts with a quantitative model of costs and revenues. Together these allow planners and policy-makers to look at financial costs and revenues from different mitigations, alongside how those mitigations improve equity and outcomes for those potentially excluded from riding transit when moving to a cashlite or cash-less fare payment system.

There are a variety of ways to approach these issues. Our team developed a model incorporating costs and revenues relating directly to the fare collection system. We then applied these models to the three case cities we explored in the survey work, mostly because we had the most familiarity and relevant survey data from riders in those areas. The model allows us to understand an overall cost-benefit framework, as well as model the effects of specific mitigation approaches across our three case cities. The model is designed to compare fare payment and mitigation "Scenarios." Each Scenario includes a different combination of fare payment systems (fareboxes, tap vending machines/TVMs), each with different abilities to collect cash. One scenario may be completely cashless, wherein fare boxes and TVMs cannot collect cash at all. Another Scenario may include fareboxes which can verify cash payments. Scenarios are based on the feedback received from transit agencies and a review of best practices nationally. Some agency feedback can be found in Appendix 1 , which includes comments about how several agencies are adapting or planning to adapt to restricted use of cash for fare payment.

Overall, we compared five Scenarios, including a base case and four mitigation scenarios. We focus here on an approach that seemed quite widespread: adding retail payment opportunities. We also added cash acceptance at fareboxes and at TVMs, for reference. In the end, our hope is that the model is flexible enough to adapt to a variety of mitigation strategies. In this vein, we developed a short guidebook to using the model and hope that transit agency staff, planners and policy-makers find it useful. The sections in this chapter describe the model, and use Portland-Gresham data throughout to illustrate the model. Further analysis of Portland-Gresham results are included in the next chapter profiling our case studies.

\subsubsection{Overall model workflow}

Figure 4.1 shows the overall workflow and relationship between the different sections of the model. Inputs are modifiable by the user and define all the costs and scenario parameters. The components of the model are explored in the following sections. 


\section{Inputs}

Revenue and cost assumptions:

Annual replacement of infrastructure (10\%)

Passenger ridership/revenues adjusted for cashacceptance

Passenger revenues remain flat years 1-10

Year 1 smartcards release equal to $1 \%$ of boardings

$10 \%$ of smartcards replaced each year

Costs of cash handling proportional to cash total

\section{Unit cost inputs:}

Cost of TVMs, Fareboxes

High cost, low cost

Cash-accepting and not cash-accepting

Annual maintenance costs - fraction of capital

Web/mobile ticketing assumed in all scenarios

Agency pays for smartcard releases

Case parameters:

Specific city/agency modal numbers

Number of stops, vehicles $->$ Farebox and TVM

numbers

Cash handling scenarios - defined by different combinations of allowing TVMs and fareboxes to accept cash, along with retail network acceptance. Other scenarios could be developed.
Quantitative Cost and Revenue Analysis

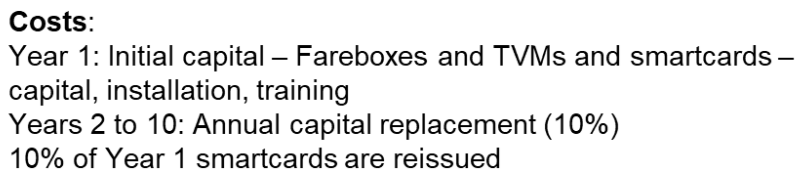

Year 1: Initial capital - Fareboxes and TVMs and smartcards capital, installation, training

Years 2 to 10: Annual capital replacement (10\%)

$10 \%$ of Year 1 smartcards are reissued

Revenues:

Years 1 to 10: Assume constant ridership/fares/revenues

\section{Scenario Results and Comparison}

Scenario 1: Total and Marginal Costs, Total and Marginal Revenues Scenario 2: Total and Marginal Costs, Total and Marginal Revenues Scenario 3: Total and Marginal Costs, Total and Marginal Revenues Scenario 4: Total and Marginal Costs, Total and Marginal Revenues

\section{Qualitative Equity Analysis}

Access: Overall access rating compared to full cash acceptance Disparities: Inequalities in access by race/ethnicity, age, income and language

Figure 4.1: Model workflow

\subsection{Quantitative Cost and Revenue Analysis}

This section describes in detail each box shown in Figure 4.1, beginning with the Inputs and those pertaining to Revenues.

\subsubsection{Ridership - Revenues}

We make several important assumptions related to ridership and revenues. We assume there are no changes in fare policies or fare levels over the 10 year model period. We also divide the most recent total annual fare revenues by the most recent annual ridership to get a fare revenue per boarding. Any increase or decrease in ridership pro rate the fare collection by that average fare. That is, we do not make any assumptions about the particular rider category (adult, senior, etc.) or fare payment type (day-pass, weekly, etc.) for riders that are excluded or included depending on fare payment scenario. These "additional riders" (additional to those able to ride in the base case) may be paying more or less than the average fare and so each Scenario may yield a different impact on increasing or decreasing revenues at the margin.

We use city-by-city survey results to inform the additional ridership (and therefore revenue) changes resulting from varied cash acceptance policies in each Scenario. The specific questions we used for an example of Portland-Gresham are shown in Table 5 below. Unfortunately, we did not design our survey to exactly ask how riders would utilize the potential fare payment Scenarios analyzed in our models. We did our best to cross tabulate from the questions and answers we did have to estimate the number of riders who would be excluded based on the fare payment Scenarios. 


\subsubsection{Costs}

Our quantitative model combines first-year capital investments along with 10 years of maintenance, operations and capital replacement into a single total cost estimate. This approach creates an overall reflection of the lifecycle costs of the fare payment system, meaning it enables us to understand the total costs from both the initial costs, as well as the recurring annual costs. Some technologies have high upfront costs but low recurring costs, while others are the opposite. By combining what may considered a lifespan of recurring costs with initial costs we can create a more apples to apples comparison between different Scenarios. For this model, we assumed a 10-year lifespan for the systems we are considering. Therefore for equipment, the model combines an initial year one cost and then nine years of equipment operating costs. The model assumes $10 \%$ of the infrastructure is replaced due to failure, vandalism or other factors each year. For cash handling and retail contracts, however, there are 10 years of operating expenses. This creates a total cost for operating the fare collection system over the 10 years, and it allows us to compare these total costs for different fare collection system Scenarios.

Unit costs for capital investments, installation, training, cash handling, and maintenance and other contingencies were gathered through interviews with experts in this area, along with reviewing other documentation related to fare collection systems deployment. Table 4.1 shows the unit costs gathered for this model. For each cost we estimate a low and a high, and report those separately throughout the model. The green cells are editable by the user in the Excel model. We assumed that the unit cost list would be the same for all cities and thus the high and low cost options should span the range of costs experienced in different regions. 
Table 4.1: Unit Costs (Portland-Gresham example)

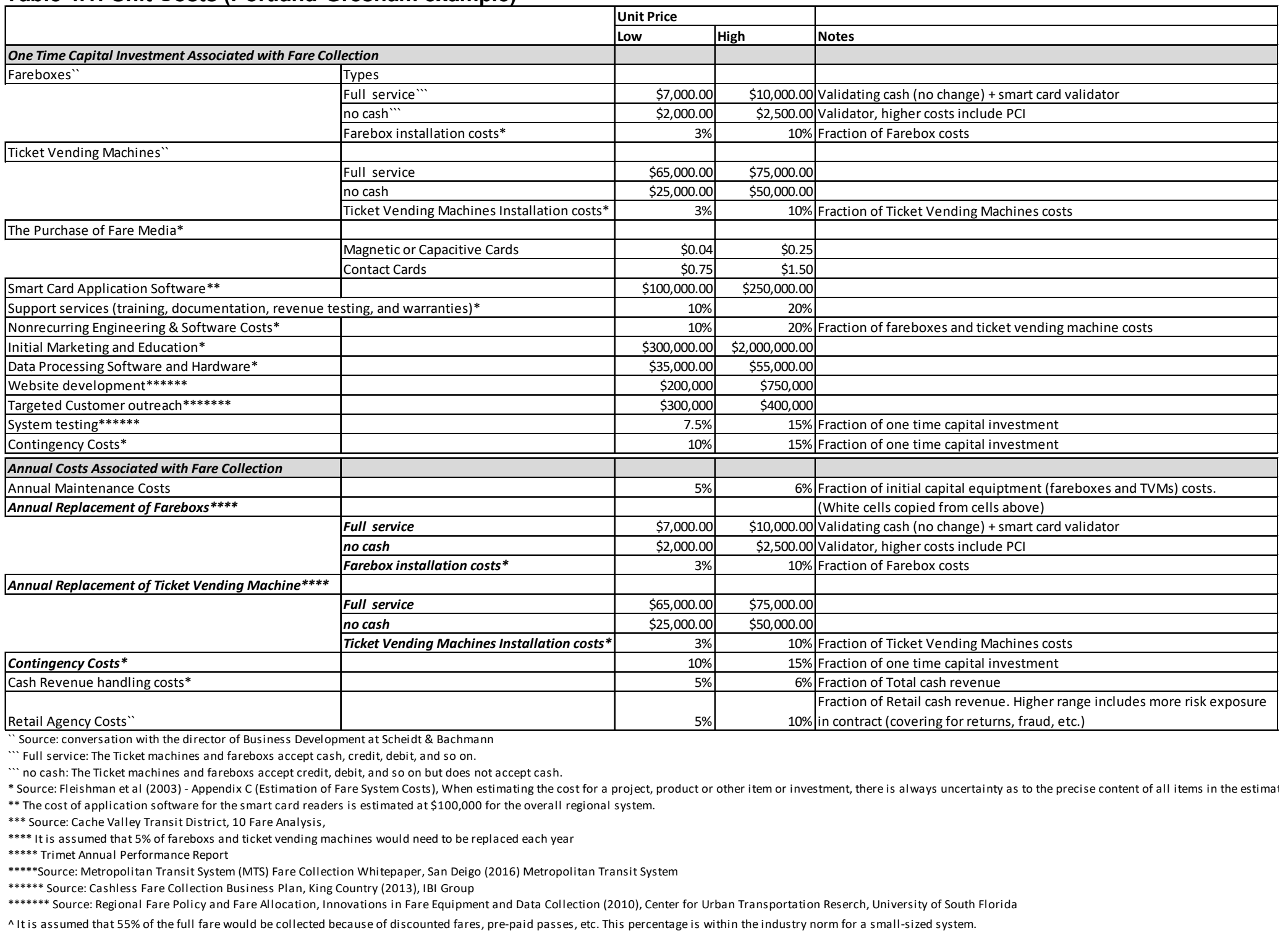




\subsubsection{Case parameters}

The model Excel file can only analyze Scenarios for one case. Each transit property is a different case, reflecting the different numbers of ticket vending machines, fareboxes, ridership, fare policies and other parameters. The model uses these parameters to calculate the total costs, ridership and revenues for the different Scenarios. Table 4.2 shows the example of Portland-Gresham.

Table 4.2: Case parameters (Portland-Gresham example)

\begin{tabular}{|l|l|l|l|l|l|}
\cline { 2 - 6 } \multicolumn{1}{c|}{} & Bus & $\begin{array}{l}\text { Light } \\
\text { Rail/BRT }\end{array}$ & $\begin{array}{l}\text { Heavy } \\
\text { Rail }\end{array}$ & Streetcar & Total \\
\hline & Bus & MAX & WES & Streetcar & \\
\hline $\begin{array}{l}\text { Annual ridership (trip origins) in } \\
\mathbf{2 0 1 9}\end{array}$ & $43,515,600$ & $30,963,600$ & 244,812 & $2,620,581$ & $77,344,593$ \\
\hline $\begin{array}{l}\text { The total number of vehicles in } \\
\mathbf{2 0 1 8}\end{array}$ & 680 & 145 & 6 & 17 & 848 \\
\hline Number of fareboxes per vehicle & 1.0 & 0.0 & 0.0 & 2.0 & \\
\hline The total number of fareboxes & 680 & 0 & 0 & 34 & 714 \\
\hline $\begin{array}{l}\text { The total number of stops or } \\
\text { stations in 2019 }\end{array}$ & 9208 & 96 & 5 & 71 & 9380 \\
\hline $\begin{array}{l}\text { Number of ticket vending } \\
\text { machines per stop or station }\end{array}$ & 0.002 & 2.1 & 2.0 & 0.0 & \\
\hline $\begin{array}{l}\text { The total number of ticket vending } \\
\text { machines }\end{array}$ & 18 & 202 & 10 & 0 & 230 \\
\hline Passenger Revenue in 2019 & $\$ 59,620,126$ & $\$ 45,634,076$ & $\$ 303,195$ & $\$ 3,590,422$ & $\$ 109,147,819$ \\
\hline Actual fare paid for one ride & $\$ 1.37$ & $\$ 1.47$ & $\$ 1.24$ & $\$ 1.37$ & $\$ 1.41$ \\
\hline
\end{tabular}

\subsubsection{Scenarios}

The model is set up to compare four Scenarios along with an additional base (no-cash) case. Each Scenario includes a different cash acceptance configuration of the fareboxes, ticket vending machines, and retail cash acceptance rates and costs. Table 4.3 shows the parameters for each of the Scenarios in our case studies. In essence, the model allows the user to compare the total costs of these different payment Scenarios, and also to compare the marginal costs of adding cash acceptance capabilities over the completely cashless base Scenario.

Table 4.3: Scenario descriptions (Portland-Gresham example)

\begin{tabular}{|l|l|l|l|}
\hline Scenario & Retail-Cash & $\begin{array}{l}\text { Farebox- } \\
\text { Cash }\end{array}$ & TVM-Cash \\
\hline Base & No & No & No \\
\hline Scenario 1 (No cash anywhere, adds retail network) & Yes & No & No \\
\hline Scenario 2 (Cash on board, not at TVMs, no retail) & No & Yes & No \\
\hline Scenario 3 (Cash only at TVMs, no retail) & No & No & Yes \\
\hline Scenario 4 (Cash accepted everywhere) & Yes & Yes & Yes \\
\hline
\end{tabular}

Table 4.4 shows how each Scenario configures cash acceptance. The base Scenario includes no cash acceptance anywhere, while the four numbered Scenarios include some combination of cash acceptance in some part of the system. The fourth Scenario includes cash accepted everywhere, including at retail locations. The share of riders 
able to ride is derived from survey data showing which riders would be able to continue riding after cash was eliminated from certain parts of the system.

Table 4.4: Scenario Ridership and Cash share of revenue (Portland-Gresham example)

\begin{tabular}{|l|l|l|}
\cline { 2 - 3 } \multicolumn{1}{l|}{ Base Case } & Full service & No cash \\
\hline Fareboxes & $0 \%$ & $100 \%$ \\
\hline Ticket Vending Machines & $0 \%$ & $100 \%$ \\
\hline Share of previous riders able to use system & $91.62 \%$ & \multicolumn{2}{|l}{} \\
\hline $\begin{array}{l}\text { Percentage of Revenue as Cash Handled by } \\
\text { Agency }\end{array}$ & $0 \%$ & \\
\hline Percentage of Revenue as Retail & $0 \%$ & \\
\hline
\end{tabular}

\begin{tabular}{|c|c|c|}
\hline $\begin{array}{l}\text { Scenario } 1 \text { (No cash anywhere, adds retail } \\
\text { network) }\end{array}$ & Full service & No cash \\
\hline Fareboxes & $0 \%$ & $100 \%$ \\
\hline Ticket Vending Machines & $0 \%$ & $100 \%$ \\
\hline Share of existing riders able to use system & \multicolumn{2}{|l|}{$95.08 \%$} \\
\hline $\begin{array}{l}\text { Percentage of Revenue as Cash Handled by } \\
\text { Agency }\end{array}$ & \multicolumn{2}{|l|}{$0 \%$} \\
\hline Percentage of Revenue as Retail & \multicolumn{2}{|l|}{$7 \%$} \\
\hline
\end{tabular}

\begin{tabular}{|l|l|l|}
\cline { 2 - 3 } \multicolumn{1}{l|}{ Scenario 2 (Cash on board, not at TVMs, no retail) } & Full service & No cash \\
\hline Fareboxes & $100 \%$ & $0 \%$ \\
\hline Ticket Vending Machines & $0 \%$ & $100 \%$ \\
\hline Share of existing riders able to use system & $96.90 \%$ & \multicolumn{1}{|l}{} \\
\hline $\begin{array}{l}\text { Percentage of Revenue as Cash Handled by } \\
\text { Agency }\end{array}$ & $6 \%$ & \\
\hline Percentage of Revenue as Retail & $0 \%$ & \\
\hline
\end{tabular}

\begin{tabular}{|l|l|l|}
\cline { 2 - 3 } \multicolumn{1}{l|}{ Scenario 3 (Cash only at TVMs, no retail) } & Full service & No cash \\
\hline Fareboxes & $0 \%$ & $100 \%$ \\
\hline Ticket Vending Machines & $100 \%$ & $0 \%$ \\
\hline Share of existing riders able to use system & $96.54 \%$ & \\
\hline $\begin{array}{l}\text { Percentage of Revenue as Cash Handled by } \\
\text { Agency }\end{array}$ & $6 \%$ & \\
\hline Percentage of Revenue as Retail & $0 \%$ & \\
\hline
\end{tabular}

\begin{tabular}{|l|l|l|}
\cline { 2 - 3 } \multicolumn{1}{l|}{ Scenario 4 (Cash accepted everywhere) } & Full service & No cash \\
\hline Fareboxes & $100 \%$ & $0 \%$ \\
\hline Ticket Vending Machines & $100 \%$ & $0 \%$ \\
\hline Share of existing riders able to use system & $100 \%$ & \multicolumn{1}{|l}{} \\
\hline $\begin{array}{l}\text { Percentage of Revenue as Cash Handled by } \\
\text { Agency }\end{array}$ & $12 \%$ & \\
\hline Percentage of Revenue as Retail & $7 \%$ & \\
\hline
\end{tabular}




\subsubsection{Share of riders able to ride in each Scenario}

The number or share of riders who would be added if certain cash options were made available is a central part of the modeling. These different boardings numbers for each scenario affects the cost per boarding and the net costs (total cost minus revenues). Unfortunately, we did not have a direct measure of this number of riders for each scenario because we did not design our survey to ask questions which would pertain directly to the cash acceptance configurations in our Scenarios. We made informed decisions based on the questions we had available. Table 4.5 shows the survey questions and analysis we did for the Portland-Gresham example.

Table 4.5: Scenario ridership calculations (Portland-Gresham example)

\begin{tabular}{|c|c|c|c|c|c|}
\hline $\begin{array}{l}\text { Ridership impact from } \\
\text { survey data }\end{array}$ & $\begin{array}{l}\text { Base (No } \\
\text { cash } \\
\text { anywhere) }\end{array}$ & $\begin{array}{l}\text { Scenario } 1 \\
\text { (No cash } \\
\text { anywhere, } \\
\text { Adds Retail } \\
\text { Network) }\end{array}$ & $\begin{array}{l}\text { Scenario } 2 \\
\text { (Cash on } \\
\text { board only) }\end{array}$ & $\begin{array}{l}\text { Scenario } 3 \\
\text { (Cash at } \\
\text { TVMs only) }\end{array}$ & $\begin{array}{l}\text { Scenario } 4 \\
\text { (Cash } \\
\text { accepted } \\
\text { everywhere) }\end{array}$ \\
\hline $\begin{array}{l}\text { Which survey questions } \\
\text { were used: }\end{array}$ & $\begin{array}{l}\text { "Excluded" = } \\
\text { Will continue } \\
\text { to need some } \\
\text { form of cash } \\
\text { if on-board } \\
\text { cash is } \\
\text { removed }\end{array}$ & $\begin{array}{l}\text { "Excluded" = } \\
\text { Can't switch } \\
\text { to cash at } \\
\text { Retail if on- } \\
\text { board cash is } \\
\text { removed }\end{array}$ & $\begin{array}{l}\text { "Excluded" = } \\
\text { Currently } \\
\text { dependent } \\
\text { only on cash } \\
\text { at TVM }\end{array}$ & $\begin{array}{l}\text { "Excluded" = } \\
\text { Can't switch } \\
\text { to cash at } \\
\text { TVMs if on- } \\
\text { board cash is } \\
\text { removed }\end{array}$ & $\begin{array}{l}\text { All riders } \\
\text { included }\end{array}$ \\
\hline $\begin{array}{l}\text { Survey respondents } \\
\text { excluded }\end{array}$ & 46 & 27 & 17 & 19 & \\
\hline $\begin{array}{l}\text { Total survey } \\
\text { respondents }\end{array}$ & 549 & 549 & 549 & 549 & \\
\hline Share Excluded & $8.4 \%$ & $4.9 \%$ & $3.1 \%$ & $3.5 \%$ & \\
\hline Share Included & $91.6 \%$ & $95.1 \%$ & $96.9 \%$ & $96.5 \%$ & $100.0 \%$ \\
\hline
\end{tabular}

\subsubsection{Results: Total Costs}

The following sections show results tables from the model. The model produced total costs for the 10 year period for each Scenario. Table 4.6 shows the example total costs for the Portland-Gresham case. It is clear that costs increase as cash capabilities are added, from a base of 2.7 cents per boarding (low unit prices) to 7.7 cents for the full cash acceptance Scenario. The high unit prices put those costs from 5.5 cents to 11.4 cents per boarding. This can be compared to the total fare collected of $\$ 1.41$ per boarding, which is assumed to remain constant in all Scenarios and for both the high and low cost models. 
Table 4.6: Total Costs - Portland-Gresham example

Financial (10-year) Costs/Benefits

\begin{tabular}{|c|c|c|c|c|}
\hline $\begin{array}{l}\text { Base (No cash } \\
\text { anywhere) }\end{array}$ & $\begin{array}{l}\text { Scenario } 1 \\
\text { (Base Case, } \\
\text { No cash } \\
\text { anywhere, } \\
\text { Adds Retail } \\
\text { Network) }\end{array}$ & $\begin{array}{l}\text { Scenario } 2 \\
\text { (Cash on } \\
\text { board, not at } \\
\text { TVMs) }\end{array}$ & $\begin{array}{l}\text { Scenario } 3 \\
\text { (Cash only at } \\
\text { TVMs) }\end{array}$ & $\begin{array}{l}\text { Scenario } 4 \\
\text { (Cash } \\
\text { accepted } \\
\text { everywhere) }\end{array}$ \\
\hline $70,863,990$ & $73,540,761$ & $74,949,587$ & $74,667,822$ & $77,344,593$ \\
\hline$\$ 19,124,126$ & $\$ 22,756,422$ & $\$ 30,714,691$ & $\$ 43,978,966$ & $\$ 59,604,422$ \\
\hline$\$ 0.027$ & $\$ 0.031$ & $\$ 0.041$ & $\$ 0.059$ & $\$ 0.077$ \\
\hline$\$ 1,000,024,644$ & $\$ 1,037,798,935$ & $\$ 1,057,680,141$ & $\$ 1,053,703,900$ & $\$ 1,091,478,190$ \\
\hline$\$ 1.41$ & $\$ 1.41$ & $\$ 1.41$ & $\$ 1.41$ & $\$ 1.41$ \\
\hline$\$ 980,900,519$ & $\$ 1,015,042,513$ & $\$ 1,026,965,450$ & $\$ 1,009,724,933$ & $\$ 1,031,873,768$ \\
\hline$\$ 38,812,241$ & $\$ 46,076,833$ & $\$ 56,301,468$ & $\$ 63,099,138$ & $\$ 88,486,373$ \\
\hline$\$ 0.055$ & $\$ 0.063$ & $\$ 0.075$ & $\$ 0.085$ & $\$ 0.114$ \\
\hline$\$ 1,000,024,644$ & $\$ 1,037,798,935$ & $\$ 1,057,680,141$ & $\$ 1,053,703,900$ & $\$ 1,091,478,190$ \\
\hline$\$ 1.41$ & $\$ 1.41$ & $\$ 1.41$ & $\$ 1.41$ & $\$ 1.41$ \\
\hline$\$ 961,212,404$ & $\$ 991,722,102$ & $\$ 1,001,378,673$ & $\$ 990,604,762$ & $\$ 1,002,991,817$ \\
\hline
\end{tabular}

Note: Colors range from red-orange-yellow-green - red meaning "bad" and green meaning "good."

\subsubsection{Results: Marginal Costs}

Also interesting is the marginal cost analysis, which illustrates the additional costs to attract additional riders who are dependent on cash for fare payment. Table 4.7 shows the example marginal costs for the Portland-Gresham case. For example, TriMet would spend $\$ 3.6$ million over 10 years (about 13.6 cents per boarding) to attract an additional 2.68 million riders per year. This comparison, again, to the $\$ 1.41$ collected from each of those additional riders. The high unit cost model puts this price at about $\$ 0.27$ per new rider. In each Scenario, adding more cash acceptance capability raises the price per new rider. In other words, Scenario One accommodates cash dependent riders at the least cost per rider. Scenario Three is the most expensive in the low unit price model, while Scenario Four is the most expensive using the high unit price model. Still, all Scenarios spend less than the fare collected to accommodate these cash-dependent riders. 
Table 4.7: Marginal Costs - Portland-Gresham example

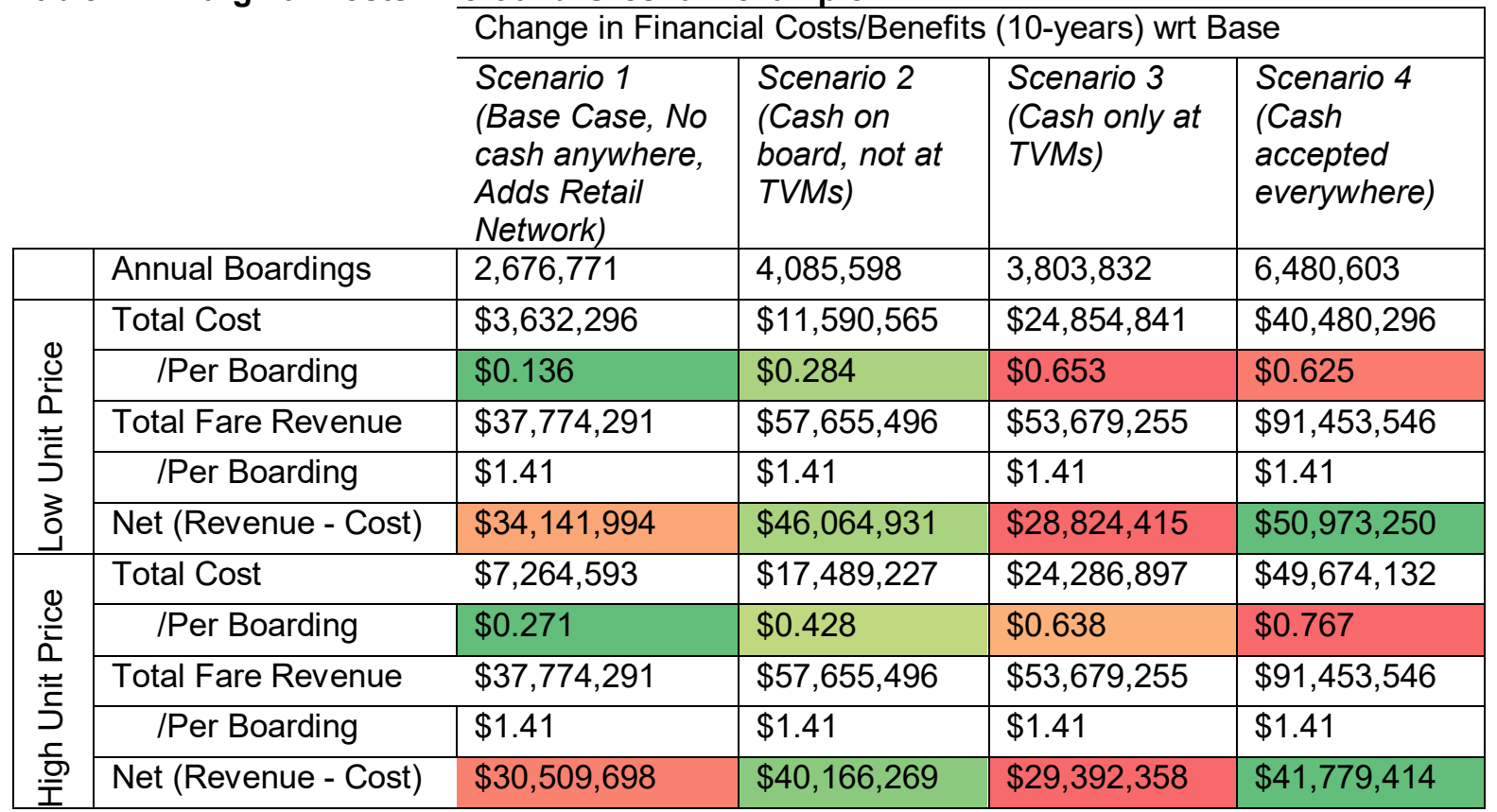

Note: Colors range from red-orange-yellow-green - red meaning "bad" and green meaning "good."

\subsection{Qualitative equity analysis}

A qualitative approach is best suited to describe immeasurable or unquantifiable qualities of fare collection scenarios, such as convenience or require technical literacy. Our team focused on three "qualities" of a fare collection practice that we believe capture some of the basic issues at hand in this analysis. These qualities include:

1. Personal costs (smartphone, credit card requirements, etc.),

2. Spatial access to purchase/reload (convenience, distance, time),

3. Technological connectivity/literacy required.

The qualities are described in more detail below where we speak more specifically about assigning scores to the different qualities.

\subsubsection{Access}

For each quality (personal cost, spatial access, technological connectivity and literacy), there is an overall "access" score given for each Scenario, reflecting how this Scenario affects access to transit payments compared to the fully cash accepting Scenario. Again - more detail on how this is scored is presented below.

\subsubsection{Disparities}

For each of the three qualities, there are also four "disparity" sub-scores given for each Scenario reflecting how social disparities exist among riders for that quality. We consider four types of social disparities:

1. Race/ethnicity

2. Age

3. Income 


\section{Language.}

For example, we found that disparities relating to personal costs fall mostly across income categories, with less significant disparities among age groups.

\subsubsection{Scoring}

Scores for overall access and for the four disparities need to be generated for each Scenario. Table 4.8 shows an example scoring. Scores were arbitrarily set to range from -2 to 0 . A score of zero means there are no access barriers or no disparities, while a '-2' means there are significant barriers or disparities. Our team determined overall access scores based on our understanding of how riders would be affected by the different Scenarios.

\subsubsection{Personal Costs}

Personal costs reflect the various additional costs incurred by riders who would need to purchase smartphones or acquire credit or bank accounts or access internet in order to adapt to new fare payment requirements. For instance, a Scenario which completely eliminated cash would require all riders to have a credit or debit card. Since most riders do have access to credit or debit cards this Scenario wouldn't score at the bottom of the scale, but we do want to recognize that it would have a big impact on those who do not have access to credit or debit cards. For a Scenario which still has some avenues for cash payment, for instance through a retail network, we assume this Scenario would impact fewer people and so the access burden for this dimension would be less (higher score).

\subsubsection{Spatial access to purchase or reload}

Spatial access reflects the length to which a rider may need to travel to load fare or acquire passes. Scenarios which restrict the locations where cash is accepted, for instance only at retail networks or at ticket vending machines, we assume would have a bigger burden on some riders than Scenarios where cash was accepted more ubiquitously. There are fewer TVMs than retail outlets or fareboxes, so we assume that TVMs would create a larger burden spatially (lower score).

\subsubsection{Technological connectivity or literacy required}

Technological connectivity and literacy reflects the knowledge and practices needed to participate in the emerging fare payment systems. While many riders will opt to purchase passes and load fare through retail networks using cash, some will opt to switch to mobile ticketing or using credit cards or other payment systems. The burden of automated fare systems will fall on those who don't have current access to credit cards, smart phones, regular Internet or reliable phone data plans. Therefore, Scenarios which reduce cash will place a larger requirement on riders to adapt technologically. 
Table 4.8: Qualitative analysis scoring (Portland-Gresham example)

\begin{tabular}{|c|c|c|c|c|c|c|}
\hline & $\begin{array}{l}\text { Base (No } \\
\text { cash } \\
\text { anywhere } \\
\text { ) }\end{array}$ & $\begin{array}{l}\text { Scenario } \\
1 \text { (Base } \\
\text { Case, No } \\
\text { cash } \\
\text { anywhere } \\
\text {, Adds } \\
\text { Retail } \\
\text { Network) }\end{array}$ & $\begin{array}{l}\text { Scenario } 2 \\
\text { (Cash on } \\
\text { board, not } \\
\text { at TVMs) }\end{array}$ & $\begin{array}{l}\text { Scenario } \\
3 \text { (Cash } \\
\text { only at } \\
\text { TVMs) }\end{array}$ & $\begin{array}{l}\text { Scenario } 4 \\
\text { (Cash } \\
\text { accepted } \\
\text { everywher } \\
\text { e) }\end{array}$ & Notes \\
\hline $\begin{array}{l}\text { Personal Costs } \\
\text { (smartphone, credit card } \\
\text { requirements, etc.) }\end{array}$ & -1 & -1 & -1 & -1 & 0 & $\begin{array}{l}\text { Fewer cash } \\
\text { opportunities = more } \\
\text { smartphones/ } \\
\text { smartcards }\end{array}$ \\
\hline $\begin{array}{l}\text { Personal Costs - Racial } \\
\text { Disparities? }\end{array}$ & -1 & 0 & 0 & 0 & 0 & $\begin{array}{l}\text { No significant } \\
\text { differences }\end{array}$ \\
\hline Age Disparities? & -2 & -1 & -1 & -1 & 0 & $\begin{array}{l}\text { Few significant } \\
\text { differences }\end{array}$ \\
\hline Income Disparities? & -2 & -1 & -1 & -1 & 0 & Significant differences \\
\hline Language Disparities? & 0 & 0 & 0 & 0 & 0 & $\begin{array}{l}\text { Focus groups did not } \\
\text { highlight strong cost } \\
\text { issues tied to language } \\
\text { proficiency }\end{array}$ \\
\hline $\begin{array}{l}\text { Spatial access to } \\
\text { purchase/reload } \\
\text { (convenience, distance, } \\
\text { time) }\end{array}$ & -1 & -1 & 0 & -1 & 0 & $\begin{array}{l}\text { Fewer cash } \\
\text { opportunities = spatial } \\
\text { access to payment is } \\
\text { more challenging. We } \\
\text { assume that on-board } \\
\text { cash acceptance } \\
\text { alleviates challenges } \\
\text { more than the other } \\
\text { solutions. }\end{array}$ \\
\hline $\begin{array}{l}\text { Spatial access to } \\
\text { purchase/reload - Racial } \\
\text { Disparities? }\end{array}$ & -1 & 0 & 0 & 0 & 0 & $\begin{array}{l}\text { Few significant } \\
\text { differences }\end{array}$ \\
\hline Age Disparities? & -1 & 0 & 0 & 0 & 0 & $\begin{array}{l}\text { Few significant } \\
\text { differences }\end{array}$ \\
\hline Income Disparities? & 0 & 0 & 0 & 0 & 0 & $\begin{array}{l}\text { No significant } \\
\text { differences }\end{array}$ \\
\hline Language Disparities? & 0 & 0 & 0 & 0 & 0 & $\begin{array}{l}\text { No significant } \\
\text { differences }\end{array}$ \\
\hline $\begin{array}{l}\text { Technological } \\
\text { connectivity/literacy } \\
\text { required }\end{array}$ & -1 & -1 & -1 & -1 & 0 & $\begin{array}{l}\text { Fewer cash } \\
\text { opportunities }= \\
\text { technological } \\
\text { literacy/connectivity } \\
\text { more important }\end{array}$ \\
\hline $\begin{array}{l}\text { Technological } \\
\text { connectivity/literacy } \\
\text { required - Racial } \\
\text { Disparities? }\end{array}$ & 0 & 0 & 0 & 0 & 0 & $\begin{array}{l}\text { No significant } \\
\text { differences }\end{array}$ \\
\hline Age Disparities? & -2 & -1 & -1 & -1 & 0 & Significant differences \\
\hline Income Disparities? & -1 & 0 & 0 & 0 & 0 & $\begin{array}{l}\text { Few significant } \\
\text { differences }\end{array}$ \\
\hline Language Disparities? & -1 & 0 & 0 & 0 & 0 & $\begin{array}{l}\text { Focus groups } \\
\text { highlighted some } \\
\text { language challenges }\end{array}$ \\
\hline
\end{tabular}

\subsubsection{Disparity scores}

Disparity scores shown in Table 4.8 are based on analyses of survey data which showed whether different groups were significantly different in their access to or use of 
different fare payment options. When responses to relevant questions in the survey were not statistically significant the disparity scores were set to zero. When there were one or two disparities that were significantly different, we lowered the disparity score to 1 for the Scenario. If there were several significant disparities we used a lower score of 2 for the no cash Scenario and then -1 for the remaining.

For instance, for survey questions relating to comfort using automated fare technologies, we reviewed the statistical test for differences among the demographic groups. The example for Portland-Gresham for disparities by income group related to technological literacy is shown in Table 4.9. In the table, bolded numbers statistically significant differences between the income groups. Since there are mild differences and only one row is showing statistically significant differences, we rated this disparity as "few" and then gave it the middle rating ( -1 for no cash, and then zero for the remaining Scenarios).

Table 4.9: Survey question results relating to comfort using automated fare technologies Portland-Gresham example

\begin{tabular}{|l|l|l|l|}
\hline & \multicolumn{4}{|l|}{ Incomes } \\
\hline & High & Low & Miss. \\
\hline Share of riders completely or somewhat uncomfortable using the following payment practices: \\
\hline Website - One Time Payment & $15 \%$ & $20 \%$ & $26 \%$ \\
\hline Website - Recurring payments & $20 \%$ & $\mathbf{2 7} \%$ & $33 \%$ \\
\hline Smartphone - Recurring payments & $16 \%$ & $24 \%$ & $28 \%$ \\
\hline Purchase by phone & $41 \%$ & $36 \%$ & $42 \%$ \\
\hline
\end{tabular}

\subsubsection{Overall scores}

We use the three access scores (green cells in Table 4.8) and the disparity scores (pink cells in Table 4.8) to create overall qualitative scores by averaging them. Table 4.10 shows the overall qualitative scores for our example Scenarios (lower scores, more red colored). The base case where no cash is accepted is clearly the worst scoring Scenario. It places the most burdens on the most riders and it also scores generally worse on the disparity scores. Eliminating cash creates high disparities based on age and income while creates less serious disparities based on language and race or ethnicity. The other Scenarios which add cash acceptance in different ways generally alleviate burdens while also reducing disparities. The Scenario where cash is added through retail networks does alleviate overall burdens and reduces disparities in most categories. An even greater improvement is found by adding cash on board capabilities. As was explained earlier, cash accepted everywhere is considered burden free and disparity free based on the framework used here, and therefore has the best score (zero, green colored). 
Table 4.10: Overall qualitative analysis averages - Portland-Gresham example $(-2=$ very problematic, $0=$ neutral/not applicable/no problem/no disparity)

\begin{tabular}{|l|l|l|l|l|l|}
\hline & $\begin{array}{l}\text { Base (No } \\
\text { cash } \\
\text { anywhere) }\end{array}$ & $\begin{array}{l}\text { Scenario 1 } \\
\text { (Base Case, } \\
\text { No cash } \\
\text { anywhere, } \\
\text { Adds Retail } \\
\text { Network) }\end{array}$ & $\begin{array}{l}\text { Scenario 2 } \\
\text { (Cash on } \\
\text { board, not at } \\
\text { TVMs) }\end{array}$ & $\begin{array}{l}\text { Scenario 3 } \\
\text { (Cash only } \\
\text { at TVMs) }\end{array}$ & $\begin{array}{l}\text { Scenario 4 } \\
\text { (Cash } \\
\text { accepted } \\
\text { everywhere) }\end{array}$ \\
\hline $\begin{array}{l}\text { General barriers to } \\
\text { use/adoption (Average } \\
\text { of three main scores) }\end{array}$ & -1.0 & -1.0 & -0.7 & -1.0 & 0.0 \\
\hline $\begin{array}{l}\text { Equity Score (Average } \\
\text { of all equity scores) }\end{array}$ & -0.9 & -0.3 & -0.3 & -0.3 & 0.0 \\
\hline $\begin{array}{l}\text { Racial Disparities } \\
\text { (Average) }\end{array}$ & -0.7 & 0.0 & 0.0 & 0.0 & 0.0 \\
\hline $\begin{array}{l}\text { Age Disparities } \\
\text { (Average) }\end{array}$ & -1.7 & -0.7 & -0.7 & -0.7 & 0.0 \\
\hline $\begin{array}{l}\text { Income Disparities } \\
\text { (Average) }\end{array}$ & -1.0 & -0.3 & -0.3 & -0.3 & 0.0 \\
\hline $\begin{array}{l}\text { Language Disparities } \\
\text { (Average) }\end{array}$ & -0.3 & 0.0 & 0.0 & 0.0 & 0.0 \\
\hline $\begin{array}{l}\text { Overall Average of All } \\
\text { Scores }\end{array}$ & -0.9 & -0.4 & -0.3 & -0.4 & 0.0 \\
\hline
\end{tabular}

Note: Colors range from red-orange-yellow-green - red meaning "bad" and green meaning "good."

We also calculated the marginal changes with respect to the base case, shown in Table 4.11. These represent how much each scenario alleviates barriers to use, or reduces disparities in the different disparities territories. We can see that Scenario Two does a slightly better job of improving scores compared to the other two scenarios, while of course Scenario Four performs the best because it is the assumed best case in removing barriers. 
Table 4.11: Marginal changes (difference from the base case) in qualitative analysis averages Portland-Gresham example $(-2=$ very problematic, $0=$ neutral $/$ not applicable $/$ no $\mathrm{problem} / \mathrm{no}$ disparity)

\begin{tabular}{|c|c|c|c|c|}
\hline & \multicolumn{4}{|c|}{ Change in Qualitative Costs/Benefits } \\
\hline & $\begin{array}{l}\text { Scenario } 1 \\
\text { (Base Case, } \\
\text { No cash } \\
\text { anywhere, } \\
\text { Adds Retail } \\
\text { Network) }\end{array}$ & $\begin{array}{l}\text { Scenario } 2 \\
\text { (Cash on } \\
\text { board, not at } \\
\text { TVMs) }\end{array}$ & $\begin{array}{l}\text { Scenario } 3 \\
\text { (Cash only } \\
\text { at TVMs) }\end{array}$ & $\begin{array}{l}\text { Scenario } 4 \\
\text { (Cash } \\
\text { accepted } \\
\text { everywhere) }\end{array}$ \\
\hline $\begin{array}{l}\text { General barriers to } \\
\text { use/adoption (Average } \\
\text { of three main scores) }\end{array}$ & 0.0 & 0.3 & 0.0 & 1.0 \\
\hline $\begin{array}{l}\text { Equity Score (Average } \\
\text { of all equity scores) }\end{array}$ & 0.7 & 0.7 & 0.7 & 0.9 \\
\hline Racial Disparities? & 0.7 & 0.7 & 0.7 & 0.7 \\
\hline Age Disparities? & 1.0 & 1.0 & 1.0 & 1.7 \\
\hline Income Disparities? & 0.7 & 0.7 & 0.7 & 1.0 \\
\hline Language Disparities? & 0.3 & 0.3 & 0.3 & 0.3 \\
\hline $\begin{array}{l}\text { Overall Average of All } \\
\text { Scores }\end{array}$ & 0.5 & 0.6 & 0.5 & 0.9 \\
\hline
\end{tabular}

Note: Colors range from red-orange-yellow-green - red meaning "bad" and green meaning "good."

\subsection{Conclusions}

The cost-benefit framework presented here includes a quantitative cost and revenue model along with a qualitative analysis of barriers and disparities. It is a common feature of cost-benefit models to include both a qualitative and quantitative side as the impacts of programs are rarely entirely quantifiable. In this model, decision makers can understand both the cost impacts and their tradeoffs with equity and access changes. In the end, therefore, there is no best option and politics and policy will determine which scenario best balances costs and benefits.

Our hope is that the framework could be modified, specifically through the modification of the unit costs, the property parameters and scenarios analyzed. It can be further modified by changing some of the rubric - especially the qualitative analysis. Different approaches to scaling barriers and disparities, along with different dimensions of such disparities could be ways for planners to tailor this model different situations. 


\section{CASE STUDIES}

We use the case studies of Eugene, Oregon; Denver, Colorado and Portland-Gresham, Oregon to explore the range of costs and benefits for the different cities and to contrast the four above Scenarios with a base case where no cash is accepted anywhere in the system. These can serve as interesting illustrations of some of the relationships between total cost of implementing cash acceptance, the total ridership and resulting revenues, the additional ridership benefits resulting from expanding cash acceptance, and the marginal costs for adding those features. Tables 5.1, 5.2 and 5.3 present the overall case parameters for the three case cities.

Table 5.1: Denver case parameters

\begin{tabular}{|l|l|l|l|l|}
\cline { 2 - 5 } \multicolumn{1}{c|}{} & Bus & $\begin{array}{l}\text { Light } \\
\text { Rail/BRT }\end{array}$ & Heavy Rail & Total \\
\hline Denver & Bus & Light Rail & $\begin{array}{l}\text { Commuter } \\
\text { Rail }\end{array}$ & \\
\hline Annual ridership (trip origins) in 2019 & $53,176,485$ & $25,476,009$ & $7,612,977$ & $86,265,471$ \\
\hline The total number of vehicles in 2018 & 1026 & 172 & 66 & 1264 \\
\hline Number of fareboxes per vehicle & 1.0 & 0.0 & & \\
\hline The total number of fareboxes & 1026 & 0 & 0 & 1026 \\
\hline The total number of stops or stations in 2019 & 9800 & 54 & 9 & 9863 \\
\hline $\begin{array}{l}\text { Number of ticket vending machines per stop or } \\
\text { station }\end{array}$ & 0.010 & 2.0 & 2.0 & \\
\hline The total number of ticket vending machines & 98 & 108 & 18 & 224 \\
\hline Passenger Revenue in 2019 & $\$ 47,167,112$ & $\$ 23,108,949$ & $\$ 15,207,946$ & $\$ 85,484,007$ \\
\hline Actual fare paid for one ride & $\$ 0.89$ & $\$ 0.91$ & $\$ 2.00$ & $\$ 0.99$ \\
\hline
\end{tabular}

Table 5.2: Eugene case parameters

\begin{tabular}{|l|l|l|l|}
\cline { 2 - 4 } \multicolumn{1}{l|}{} & Bus & Light Rail/BRT & Total \\
\hline Eugene & Bus & $\begin{array}{l}\text { Emerald Express } \\
\text { (EmX) BRT }\end{array}$ & \\
\hline Annual ridership (trip origins) in 2019 & $6,650,100$ & $3,496,291$ & $10,146,391$ \\
\hline The total number of vehicles in $\mathbf{2 0 1 8}$ & 77 & 13 & 90 \\
\hline Number of fareboxes per vehicle & 1.0 & 0.0 & \\
\hline The total number of fareboxes & 77 & 0 & 77 \\
\hline The total number of stops or stations in 2019 & 1189 & 76 & 1265 \\
\hline $\begin{array}{l}\text { Number of ticket vending machines per stop or } \\
\text { station }\end{array}$ & 0.010 & 1.2 & \\
\hline The total number of ticket vending machines & 12 & 91 & 103 \\
\hline Passenger Revenue in 2019 & $\$ 4,540,703$ & $\$ 2,563,108$ & $\$ 7,103,811$ \\
\hline Actual fare paid for one ride & $\$ 0.68$ & $\$ 0.73$ & $\$ 0.70$ \\
\hline
\end{tabular}


Table 5.3: Portland-Gresham case parameters

\begin{tabular}{|l|l|l|l|l|l|}
\cline { 2 - 6 } \multicolumn{1}{c|}{} & Bus & $\begin{array}{l}\text { Light Light } \\
\text { Rail/BRT }\end{array}$ & $\begin{array}{l}\text { Heavy } \\
\text { Rail }\end{array}$ & Streetcar & Total \\
\hline Portland-Gresham & Bus & MAX & WES & Streetcar & \\
\hline Annual ridership (trip origins) in 2019 & $43,515,600$ & $30,963,600$ & 244,812 & $2,620,581$ & $77,344,593$ \\
\hline The total number of vehicles in 2018 & 680 & 145 & 6 & 17 & 848 \\
\hline Number of fareboxes per vehicle & 1.0 & 0.0 & 0.0 & 2.0 & \\
\hline The total number of fareboxes & 680 & 0 & 0 & 34 & 714 \\
\hline $\begin{array}{l}\text { The total number of stops or stations } \\
\text { in 2019 }\end{array}$ & 9208 & 96 & 5 & 71 & 9380 \\
\hline $\begin{array}{l}\text { Number of ticket vending machines } \\
\text { per stop or station }\end{array}$ & 0.002 & 2.1 & 2.0 & 0.0 & \\
\hline $\begin{array}{l}\text { The total number of ticket vending } \\
\text { machines }\end{array}$ & 18 & 202 & 10 & 0 & 230 \\
\hline Passenger Revenue in 2019 & $\$ 59,620,126$ & $\$ 45,634,076$ & $\$ 303,195$ & $\$ 3,590,422$ & $\$ 109,147,819$ \\
\hline Actual fare paid for one ride & $\$ 1.37$ & $\$ 1.47$ & $\$ 1.24$ & $\$ 1.37$ & $\$ 1.41$ \\
\hline
\end{tabular}

\subsection{Quantitative analysis of costs and revenues}

The first analysis is the cost and revenue calculations for the four Scenarios in each of the three case cities. Table 5.4 shows compares total costs and revenues for the 10 year model. Numbers are shaded from red to green where red generally means less desirable and green is more desirable. On the cost side, red are higher costs, while on the revenue side, red are lower revenues. A few patterns stand out from this analysis.

\subsubsection{Large range of costs to collect fares}

The first is the significant range of costs to collect fare between the two larger metro areas and Eugene. Eugene spends almost 5 times as much in the base Scenario to collect fares compared to Denver and Portland - Gresham. In the Scenario Four, Eugene is still nearly 3 times as expensive. Furthermore, it is collecting less revenue per boarding. While it is not an aim of this project to look at considering fare free systems, the case of Eugene illustrates how smaller properties should probably consider going fare free, considering that a large share of fare revenues is spent to collect fare.

\subsubsection{Different Scenarios maximize net revenues}

Interestingly, comparing the net benefit rose for the different properties, we can see that generally Scenario Two, which adds cash collection on buses, maximizes revenues, net of costs. The Portland-Gresham case is slightly different from the other cases in that the full cash accepting Scenario (Four) is very close to Scenario Two. This is likely because of the significantly higher revenue per boarding for Portland-Gresham compared to the other two cities, as well as the different survey responses used to estimate ridership for the different Scenarios. 
Table 5.4: Comparison of costs and revenues for the three agencies

\begin{tabular}{|c|c|c|c|c|c|}
\hline \multirow[b]{2}{*}{ Denver } & \multicolumn{5}{|c|}{ Financial (10-year) Costs/Benefits } \\
\hline & $\begin{array}{l}\text { Base (No } \\
\text { cash } \\
\text { anywhere) }\end{array}$ & $\begin{array}{l}\text { Scenario } 1 \\
\text { (Base Case, } \\
\text { No cash } \\
\text { anywhere, } \\
\text { Adds Retail } \\
\text { Network) }\end{array}$ & $\begin{array}{l}\text { Scenario } 2 \\
\text { (Cash on } \\
\text { board, not at } \\
\text { TVMs) }\end{array}$ & $\begin{array}{l}\text { Scenario } 3 \\
\text { (Cash only } \\
\text { at TVMs) }\end{array}$ & $\begin{array}{l}\text { Scenario } 4 \\
\text { (Cash } \\
\text { accepted } \\
\text { everywhere) }\end{array}$ \\
\hline Annual Boardings & $74,013,760$ & $77,873,888$ & $86,265,471$ & $82,405,343$ & $86,265,471$ \\
\hline Cost Per Boarding & $\$ 0.054$ & $\$ 0.059$ & $\$ 0.073$ & $\$ 0.077$ & $\$ 0.107$ \\
\hline Revenue Per Boarding & $\$ 0.99$ & $\$ 0.99$ & $\$ 0.99$ & $\$ 0.99$ & $\$ 0.99$ \\
\hline $\begin{array}{l}\text { Net Benefit (Revenue - } \\
\text { Cost) }\end{array}$ & $\$ 693,109,208$ & $\$ 725,959,016$ & $\$ 791,778,948$ & $\$ 753,367,579$ & $\$ 762,760,083$ \\
\hline \multicolumn{6}{|l|}{ Portland-Gresham } \\
\hline Annual Boardings & $70,863,990$ & $73,540,761$ & $74,949,587$ & $74,667,822$ & $77,344,593$ \\
\hline Cost Per Boarding & $\$ 0.055$ & $\$ 0.063$ & $\$ 0.075$ & $\$ 0.085$ & $\$ 0.114$ \\
\hline Revenue Per Boarding & $\$ 1.41$ & $\$ 1.41$ & $\$ 1.41$ & $\$ 1.41$ & $\$ 1.41$ \\
\hline $\begin{array}{l}\text { Net Benefit (Revenue - } \\
\text { Cost) }\end{array}$ & $\$ 961,212,404$ & $\$ 991,722,102$ & $\$ 1,001,378,673$ & $\$ 990,604,762$ & $\$ 1,002,991,817$ \\
\hline \multicolumn{6}{|l|}{ Eugene } \\
\hline Annual Boardings & $6,554,241$ & $8,910,822$ & $10,146,391$ & $8,428,051$ & $10,146,391$ \\
\hline Cost Per Boarding & $\$ 0.259$ & $\$ 0.196$ & $\$ 0.184$ & $\$ 0.313$ & $\$ 0.282$ \\
\hline Revenue Per Boarding & $\$ 0.70$ & $\$ 0.70$ & $\$ 0.70$ & $\$ 0.70$ & $\$ 0.70$ \\
\hline $\begin{array}{l}\text { Net Benefit (Revenue - } \\
\text { Cost) }\end{array}$ & $\$ 28,904,244$ & $\$ 44,966,705$ & $\$ 52,322,825$ & $\$ 32,626,019$ & $\$ 42,384,888$ \\
\hline
\end{tabular}

Note: Colors range from red-orange-yellow-green - red meaning "bad" and green meaning "good."

\subsection{Marginal cost analysis}

Now exploring the marginal costs, shown in Table 5.5, we can focus the analysis on the cost per new rider, above the base case. It is clear that Scenario One adds new riders at the least cost per new rider for all three case cities. Scenario Two also is quite inexpensive per new rider, but still significantly more costly than Scenario One in all cities. The other two Scenarios are much more expensive. The additional (net) revenue generated by the Scenarios, again compared to the base case, is highest for Scenario Two (other than Portland-Gresham where Scenario Four is slightly higher than Scenario Two). It's interesting to compare Denver with Portland-Gresham here: Denver adds significantly more riders than Portland when it adds cash acceptance meaning that the cost per new rider is quite low. Similarly for Eugene, adding cash acceptance significantly expands ridership and so the cost of offering cash acceptance compared to the revenues that generates is quite low. For example, by adding cash-on-board, Eugene only spends 4.8 cents per boarding to collect 70 cents in fare, while PortlandGresham spends 43 cents (but to collect \$1.41). On the other hand, PortlandGresham's revenue per boarding is much higher than Denver or Eugene and so even though it spends more money to collect, its highest net revenue is the full cash accepting Scenario Four (spending almost 77 cents per boarding to collect fare). 
Table 5.5: Comparison of marginal costs and revenues for the three agencies

\begin{tabular}{|c|c|c|c|c|}
\hline \multirow[b]{2}{*}{ Denver } & \multicolumn{4}{|c|}{ Change in Financial Costs/Benefits (10-years) wrt Base } \\
\hline & $\begin{array}{l}\text { Scenario } 1 \\
\text { (Base Case, } \\
\text { No cash } \\
\text { anywhere, } \\
\text { Adds Retail } \\
\text { Network) }\end{array}$ & $\begin{array}{l}\text { Senario } 2 \\
\text { (Cash on } \\
\text { board, not at } \\
\text { TVMs) }\end{array}$ & $\begin{array}{l}\text { Senario } 3 \\
\text { (Cash only } \\
\text { at TVMs) }\end{array}$ & $\begin{array}{l}\text { Senario } 4 \\
\text { (Cash } \\
\text { accepted } \\
\text { everywhere) }\end{array}$ \\
\hline Annual Boardings & $3,860,128$ & $12,251,711$ & $8,391,583$ & $12,251,711$ \\
\hline Cost Per Boarding & $\$ 0.140$ & $\$ 0.186$ & $\$ 0.273$ & $\$ 0.422$ \\
\hline Revenue Per Boarding & $\$ 0.99$ & $\$ 0.99$ & $\$ 0.99$ & $\$ 0.99$ \\
\hline $\begin{array}{l}\text { Net Benefit (Revenue - } \\
\text { Cost) }\end{array}$ & $\$ 32,849,808$ & $\$ 98,669,739$ & $\$ 60,258,370$ & $\$ 69,650,875$ \\
\hline \multicolumn{5}{|l|}{ Portland-Gresham } \\
\hline Annual Boardings & $2,676,771$ & $4,085,598$ & $3,803,832$ & $6,480,603$ \\
\hline Cost Per Boarding & $\$ 0.271$ & $\$ 0.428$ & $\$ 0.638$ & $\$ 0.767$ \\
\hline Revenue Per Boarding & $\$ 1.41$ & $\$ 1.41$ & $\$ 1.41$ & $\$ 1.41$ \\
\hline $\begin{array}{l}\text { Net Benefit (Revenue - } \\
\text { Cost) }\end{array}$ & $\$ 30,509,698$ & $\$ 40,166,269$ & $\$ 29,392,358$ & $\$ 41,779,414$ \\
\hline \multicolumn{5}{|l|}{ Eugene } \\
\hline Annual Boardings & $2,356,581$ & $3,592,150$ & $1,873,809$ & $3,592,150$ \\
\hline Cost Per Boarding & $\$ 0.019$ & $\$ 0.048$ & $\$ 0.502$ & $\$ 0.325$ \\
\hline Revenue Per Boarding & $\$ 0.70$ & $\$ 0.70$ & $\$ 0.70$ & $\$ 0.70$ \\
\hline $\begin{array}{l}\text { Net Benefit (Revenue - } \\
\text { Cost) }\end{array}$ & $\$ 16,062,461$ & $\$ 23,418,581$ & $\$ 3,721,776$ & $\$ 13,480,645$ \\
\hline
\end{tabular}

Note: Colors range from red-orange-yellow-green - red meaning "bad" and green meaning "good."

\subsection{Equity analysis}

Table 5.6 shows the equity analysis for the three cities. Looking at the top row of the table for each city, we can see that Denver and Eugene have significantly higher barriers to adoption than Portland-Gresham. Looking at the overall equity score, Denver appears to have fewer disparities than the other two cities overall for the base case, but similar disparities for the other scenarios. Both Denver and Portland-Gresham appeared to have little to no disparities by race and language, while Eugene also has few disparities by language. All three cities show significant disparities by age and moderate disparities by income. 
Table 5.6: Qualitative equity analysis for the three agencies Qualitative Costs/Benefits

Base (No
cash
anywhere)

Scenario 1
(Base Case,
No cash
anywhere,
Adds Retail
Network)

\begin{tabular}{|l|} 
Scenario 2 \\
(Cash on \\
board, not at \\
TVMs)
\end{tabular}

Scenario 3 (Cash only anywhere)

Denver

\begin{tabular}{|c|c|c|c|c|c|}
\hline $\begin{array}{l}\text { General barriers to use/adoption } \\
\text { (Average of barrier scores) }\end{array}$ & -1.7 & -1.7 & -1.3 & -1.7 & 0.0 \\
\hline $\begin{array}{l}\text { Equity Score (Average of all equity } \\
\text { scores) }\end{array}$ & -0.5 & -0.3 & -0.3 & -0.3 & 0.0 \\
\hline Racial Disparities? & 0.0 & 0.0 & 0.0 & 0.0 & 0.0 \\
\hline Age Disparities? & -1.3 & -0.7 & -0.7 & -0.7 & 0.0 \\
\hline Income Disparities? & -0.7 & -0.3 & -0.3 & -0.3 & 0.0 \\
\hline Language Disparities? & 0.0 & 0.0 & 0.0 & 0.0 & 0.0 \\
\hline Overall Average of All Scores & -0.7 & -0.5 & -0.5 & -0.5 & 0.0 \\
\hline \multicolumn{6}{|l|}{ Portland-Gresham } \\
\hline $\begin{array}{l}\text { General barriers to use/adoption } \\
\text { (Average of barrier scores) }\end{array}$ & -1.0 & -1.0 & -0.7 & -1.0 & 0.0 \\
\hline $\begin{array}{l}\text { Equity Score (Average of all equity } \\
\text { scores) }\end{array}$ & -0.9 & -0.3 & -0.3 & -0.3 & 0.0 \\
\hline Racial Disparities? & -0.7 & 0.0 & 0.0 & 0.0 & 0.0 \\
\hline Age Disparities? & $\begin{array}{l}1.7 \\
\end{array}$ & -0.7 & -0.7 & -0.7 & 0.0 \\
\hline Income Disparities? & -1.0 & -0.3 & -0.3 & -0.3 & 0.0 \\
\hline Language Disparities? & -0.3 & 0.0 & 0.0 & 0.0 & 0.0 \\
\hline Overall Average of All Scores & -0.9 & -0.4 & -0.3 & -0.4 & 0.0 \\
\hline \multicolumn{6}{|l|}{ Eugene } \\
\hline $\begin{array}{l}\text { General barriers to use/adoption } \\
\text { (Average of barrier scores) }\end{array}$ & -2.0 & -2.0 & -1.7 & -2.0 & 0.0 \\
\hline $\begin{array}{l}\text { Equity Score (Average of all equity } \\
\text { scores) }\end{array}$ & -0.8 & -0.3 & -0.3 & -0.3 & 0.0 \\
\hline Racial Disparities? & -1.0 & -0.3 & -0.3 & -0.3 & 0.0 \\
\hline Age Disparities? & -1.3 & -0.7 & -0.7 & -0.7 & 0.0 \\
\hline Income Disparities? & -0.7 & -0.3 & -0.3 & -0.3 & 0.0 \\
\hline Language Disparities? & -0.3 & 0.0 & 0.0 & 0.0 & 0.0 \\
\hline Overall Average of All Scores & -1.1 & -0.7 & -0.6 & -0.7 & 0.0 \\
\hline
\end{tabular}

Note: Colors range from red-orange-yellow-green - red meaning "bad" and green meaning "good."

Looking at the marginal impacts on the qualitative scores in Table 5.7, it does seem generally that Scenario Two reduces disparities more than Scenarios One or three. Of course, this reflects our assumption that collecting cash on board buses reduces barriers to payment more than a ticket vending machines or retail. This assumption may not be the same in all regions. Scenario Four reduces significantly all the disparities (shows the greatest positive improvement), since that was an assumption of our scoring. 
Table 5.7: Marginal change in qualitative equity analysis for the three agencies

\begin{tabular}{|c|c|c|c|c|}
\hline \multirow[b]{2}{*}{ Denver } & \multicolumn{4}{|c|}{ Change in Qualitative Costs/Benefits WRT base case } \\
\hline & $\begin{array}{l}\text { Scenario } 1 \\
\text { (Base Case, } \\
\text { No cash } \\
\text { anywhere, } \\
\text { Adds Retail } \\
\text { Network) }\end{array}$ & $\begin{array}{l}\text { Scenario } 2 \\
\text { (Cash on } \\
\text { board, not at } \\
\text { TVMs) }\end{array}$ & $\begin{array}{l}\text { Scenario } 3 \\
\text { (Cash only } \\
\text { at TVMs) }\end{array}$ & $\begin{array}{l}\text { Scenario } 4 \\
\text { (Cash } \\
\text { accepted } \\
\text { everywhere) }\end{array}$ \\
\hline $\begin{array}{l}\text { General barriers to use/adoption } \\
\text { (Average of barrier scores) }\end{array}$ & 0.0 & 0.3 & 0.0 & 1.7 \\
\hline $\begin{array}{l}\text { Equity Score (Average of all equity } \\
\text { scores) }\end{array}$ & 0.3 & 0.3 & 0.3 & 0.5 \\
\hline Racial Disparities? & 0.0 & 0.0 & 0.0 & 0.0 \\
\hline Age Disparities? & 0.7 & 0.7 & 0.7 & 1.3 \\
\hline Income Disparities? & 0.3 & 0.3 & 0.3 & 0.7 \\
\hline Language Disparities? & 0.0 & 0.0 & 0.0 & 0.0 \\
\hline Overall Average of All Scores & 0.2 & 0.3 & 0.2 & 0.7 \\
\hline \multicolumn{5}{|l|}{ Portland-Gresham } \\
\hline $\begin{array}{l}\text { General barriers to use/adoption } \\
\text { (Average of barrier scores) }\end{array}$ & 0.0 & 0.3 & 0.0 & 1.0 \\
\hline $\begin{array}{l}\text { Equity Score (Average of all equity } \\
\text { scores) }\end{array}$ & 0.7 & 0.7 & 0.7 & 0.9 \\
\hline Racial Disparities? & 0.7 & 0.7 & 0.7 & 0.7 \\
\hline Age Disparities? & 1.0 & 1.0 & 1.0 & 1.7 \\
\hline Income Disparities? & 0.7 & 0.7 & 0.7 & 1.0 \\
\hline Language Disparities? & 0.3 & 0.3 & 0.3 & 0.3 \\
\hline Overall Average of All Scores & 0.5 & 0.6 & 0.5 & 0.9 \\
\hline \multicolumn{5}{|l|}{ Eugene } \\
\hline $\begin{array}{l}\text { General barriers to use/adoption } \\
\text { (Average of barrier scores) }\end{array}$ & 0.0 & 0.3 & 0.0 & 2.0 \\
\hline $\begin{array}{l}\text { Equity Score (Average of all equity } \\
\text { scores) }\end{array}$ & 0.5 & 0.5 & 0.5 & 0.8 \\
\hline Racial Disparities? & 0.7 & 0.7 & 0.7 & 1.0 \\
\hline Age Disparities? & 0.7 & 0.7 & 0.7 & 1.3 \\
\hline Income Disparities? & 0.3 & 0.3 & 0.3 & 0.7 \\
\hline Language Disparities? & 0.3 & 0.3 & 0.3 & 0.3 \\
\hline Overall Average of All Scores & 0.4 & 0.5 & 0.4 & 1.1 \\
\hline
\end{tabular}

Note: Colors range from red-orange-yellow-green - red meaning "bad" and green meaning "good."

Reviewing the whole picture reveals interesting conclusions. Scenario Two appears to create significant qualitative benefit, while adding cash dependent riders at a lower cost than Scenarios Three and Four. While Scenario Four clearly creates the most equitable system, it comes at a high cost. Scenario One spends very little and also achieves improvements in lowering barriers and reducing disparities, though again not as much in Scenario Two. These results depend strongly on the number of riders added under each scenario, but we imagine that for most agencies, the general patterns will hold, since they seem to hold for the three agencies included here. We expand on some of these general conclusions in the next, final section. 


\section{LESSONS FOR TRANSITIONS TO CASH-LIMITED FARE PAYMENT WITH EQUITY}

While our models were built fairly specifically to look at three agencies, relying on detailed survey information and focus group discussions, there are some general takeaways here that could be important for navigating the transition to reducing cash in fare payments.

\subsection{Larger properties spend less to collect fare}

Perhaps not surprisingly, our larger metro areas profile here spend much less to collect fares than smaller ones. This is salient because both the total, then marginal, costs of adding fare collection capabilities are important factor in decision-making around equity mitigations. Based on the results here, it seems much more prudent for larger agencies to make the effort to expand cash collection capabilities for as long as possible, since they more than pay for themselves from the increased fare revenue. And of course, they are alleviating important barriers to fare payment for a large population. All the mitigations we profile here cost much less than the fares they collected. If equity is truly the goal, then agencies should strive to add these capabilities for as long as reasonably possible.

The next logical conclusion from this pattern is that for smaller properties, they should seriously consider going completely fare free. Across the board, our Eugene case showed that fare collection consumes a large part of fare revenues - about $40 \%$ of the revenues in the full cash scenario are spent collecting fare. This approach obviously would benefit low income riders and those potentially excluded by technological transitions, but benefit other riders as well.

\subsection{Simple cash collection on buses could be an important bridge}

Our analysis show that simple cash collection on board buses is perhaps the least costly way of expanding cash collection capabilities. This rests on our assumption that unit costs for simple cash collection (not verifying) fareboxes are quite inexpensive, compared to cash verifying fareboxes or ticket vending machines. And according to the ridership survey data, this mitigation also added significant ridership. For instance, for the Eugene case, cash on board added so significantly to ridership that the average cost to collect fare actually is less than just the retail network scenario. This may not be the case in all regions depending on the configuration of retail, ticket vending machines and the bus network coverage.

\subsection{Retail is a lowest cost option}

Based on the unit cost research we included in our models, retail is by far the lowest cost option to add cash capabilities in terms of total cost, net costs, and in terms of cost to attract new riders. It was the most commonly cited mitigation from our interviews with agencies. Our assumptions, however is that the retail network still poses significant geographical barriers for many riders, and does not offer the kind of coverage and access that cash collection on board would offer. Still, for the larger regions, the costs of 
moving from retail to cash on board was only about $50 \%$ more per new rider and so should still be considered, perhaps alongside retail. For the smaller areas analyzed, however, moving from retail to cash on board cost per new boarding quite significantly.

\subsection{When larger numbers of riders are excluded, equity mitigations are cheaper}

Our model looks at both total costs, but also the cost of providing access for each additional rider who may be excluded in the base case where cash is not collected at all. The larger number of riders that are excluded, the bigger impact equity mitigations have and the cheaper they are per additional rider, and per additional fare collected. Our Portland-Gresham case showed relatively few riders were excluded when cash was eliminated compared to the other properties. That meant that adding retail cash collection cost \$0.27 per new boarding. For Denver and Eugene where larger populations were excluded, adding retail capabilities only cost $\$ 0.14$ and 1.9 cents respectively. Similar trends followed for the other mitigation strategies. 


\section{REFERENCES}

Allen, K. "New York City could Become latest to Punish Cashless Businesses". ABC News. https://abcnews.go.com/Business/york-city-latest-punish-cashlessbusinesses/story?id=64492022. Accessed 07-24-2019, 2019.

Altstadt, R. 2019. "Portland-Vancouver's Hop Fastpass Becomes First Transit Fare Card in North America on iPhone", [Press Release], http://news.trimet.org/2019/05/portland-vancouvers-hop-fastpass-becomes-first-transitfare-card-in-north-america-on-iphonel.

Altstadt, R. "Time to hop on board as TriMet, C-TRAN and Portland Streetcar officially launch Hop Fastpass your new ticket to ride". http://news.trimet.org/2017/07/time-tohop-on-board-as-trimet-c-tran-and-portland-streetcar-officially-launch-hop-fastpassyour-new-ticket-to-ridel. Accessed 07-29-2019, 2019.

Altstadt, R. "TriMet plans to phase out most non-Hop paper and mobile tickets and passes by Dec. 31, 2019". http://news.trimet.org/2019/04/trimet-plans-to-phase-outmost-paper-tickets-and-passes-by-december-31-2019/. Accessed 07-26-2019, 2019.

Apaam, G., S. Burhouse, K. Chu, K. Ernst, K. Fritzdixon, R. Goodstein, A. Lloro, C. Opoku, Y. Osaki, D. Sharma, and J. Weinstein. "2017 FDIC National Survey of Unbanked and Underbanked Households ". Federal Deposit Insurance Corporation, 2018 https://www.fdic.gov/householdsurvey/2017/2017report.pdf.

Bhunia, P. "Singapore Aims to Achieve Fully Cashless Public Transport System by 2020". https://www.opengovasia.com/singapore-aims-to-achieve-fully-cashless-publictransport-system-by-2020/. Accessed 08-13-2019, 2019.

Brakewood, C. "Business Models for Mobile Fare Apps". Transit Cooperative Research Program: Transportation Research Board, 2020.

Brakewood, C., and G. Kocur. "Modeling Transit Rider Preferences for Contactless Bank Cards as Fare Media: Transport for London and the Chicago, Illinois Transit Authority." Transportation Research Record, 2011. 2216: 100-107.

Brakewood, C., F. Rojas, J. Robin, J. Sion, and S. Jordan. "Forecasting mobile ticketing adoption on commuter rail." Journal of Public Transportation, 2014. 17: 1-19.

Brakewood, C. E. "Contactless prepaid and bankcards in transit fare collection systems." Massachusetts Institute of Technology, 2010.

Brinklow, A. "San Francisco Officially Bans Cashless Stores". https://sf.curbed.com/2019/5/8/18536575/san-francisco-cashless-store-ban-valliebrown-amazon. Accessed 07-24-2019, 2019.

CH2M Hill. "eFare - Hop Program, ODOT Regions 1 and 2: Gap Analysis - Hop Fastpass Feasibility". 2017 
https://www.oregon.gov/ODOT/RPTD/RPTD\%20Document\%20Library/eFareExpansion-Gap-Analysis.pdf.

Clark, H. M., S. Barlow, P. Heller, and K. Maloney. "A Survey of Intercity Transit Passengers". 2015

https://www.intercitytransit.com/sites/default/files/CustomerSatisfaction2015.pdf.

DHM Research. "TriMet Attitude and Awareness Survey". 2018

https://trimet.org/research/pdf/attitude-awareness-2018.pdf.

Dickens, M. "2018 Public Transportation Fare Database ". American Public

Transportation Association, Washington, DC, 2019 https://www.apta.com/researchtechnical-resources/transit-statistics/fare-database/.

Eby, B. "Dockless Bikesharing Companies are Testing New Approaches to Improve Equity." In Eno Transportation Weekly,,, No. Week of June 11,2018, Eno Center for Transportation, 2018.

Formby, B. "No debit card? No problem, with DART's new fare system". https://www.dallasnews.com/news/transportation/2016/05/16/darts-new-fare-systemaims-to-make-mobility-easier-for-passengers-without-bank-accounts. Accessed 05-292019, 2019.

Georggi, N. L., C. Brakewood, S. Barbeau, and A. Joslin. "A Concept of Operations for Deploying a Mobile Transit Fare Collection App". Presented at TRB 96th Annual Meeting, Washington D.C., 2017.

Geuss, M. "New Jersey becomes second state to ban cashless shops and restaurants". https://arstechnica.com/tech-policy/2019/03/new-iersey-becomes-second-state-to-bancashless-shops-and-restaurants/. Accessed 07-29-2019, 2019.

GVB Public Transport. "GVB Public Transport is Cashless". Accessed 08-13-2019, 2019.

Howland, S., Nathan McNeil, J. Broach, K. Rankins, J. MacArthur, and J. Dill. "Breaking Barriers to Bike Share: Insights on Equity from a Survey of Bike Share System Owners and Operators". Transportation Research and Education Center (TREC), Portland, OR, 2017

https://trec.pdx.edu/research/project/884/Evaluating Efforts to Improve the Equity of Bike Share Systems.

King, D. A., and J. F. Saldarriaga. "Access to taxicabs for unbanked households: An exploratory analysis in New York City." Journal of Public Transportation, 2017. 20: 1.

LimeBike. 2017. "Cash for LimeBike Pilot Program Gives Bike Access to Seattleites without a Smartphone", [Press Release], https://docs.google.com/document/d/1IKD7CJC15eYigEqU8PG tWw4I wFUywlCyE6c MF8IJo/edit Accessed 08-20-2019.

Marshall, A. "New York Transit Edges Into a Future Without MetroCards". WIRED. https://www.wired.com/story/new-york-transit-edges-future-without-metrocards/.

Accessed 06-06-2019, 2019. 
Mavadiya, M. "The US Will Not Be Cashless Anytime Soon". Forbes. https://www.forbes.com/sites/madhvimavadiya/2019/02/24/the-us-will-not-be-cashlessanytime-soon/\#17f15cc93204. Accessed 07-17-2019, 2019.

McNeil, N., J. MacArthur, J. Broach, A. Cummings, R.-L. Stark, R. Sanders, and A. Witte. "National Scan of Bike Share Equity Programs: Approaches and Best Practices for Promoting Equity in Bike Share." 2019. .

Metro Research. "On-Board Survey Results + Trend Report". 2018 http://media.metro.net/projects studies/research/images/infographics/survey-researchonboard 2018.pdf.

Nelson, L. "Understanding the pros and cons of cashless fare payment for buses". https://mobilitylab.org/2018/10/16/understanding-the-pros-and-cons-of-cashless-farepayment-for-buses/. Accessed 07-22-2019, 2019.

PayNearMe. "Dallas Area Rapid Transit Partners with PayNearMe to Reduce Cash Handling by Transit Operators". https://cash.paynearme.com/en/about/press/dallasarea-rapid-transit-partners-paynearme-reduce-cash-handling-transit-operators/. Accessed 07-26-2019, 2019.

PayNearMe. "DART GoPass App Launch". https://home.paynearme.com/press/dartgopass-app-launch/. Accessed 07-26-2019, 2019.

Pew Research Center. "Digital gap between rural and nonrural America persists". https://www.pewresearch.org/fact-tank/2019/05/31/digital-gap-between-rural-andnonrural-america-persists/. Accessed 07-23-2019, 2019.

Pew Research Center. "Mobile Fact Sheet". https://www.pewinternet.org/factsheet/mobile/. Accessed 07-24-2019, 2019.

Rahman, S., J. Wong, and C. Brakewood. "Use of mobile ticketing data to estimate an origin-destination matrix for New York City ferry service." Transportation Research Record: Journal of the Transportation Research Board, 2016. 1-9.

RSG. "Regional Transportation Authority: 2016 Customer Satisfaction Study". 2017 https://www.rtachicago.org/sites/default/files/documents/plansandprograms/RegionalTransportation-Authority -2016-Customer-Satisfaction-Study.pdf.

Shaheen, S., C. Bell, A. Cohen, and B. Yelchuru. "Travel Behavior: Shared Mobility and Transportation Equity". 2017.

Shirgaokar, M. "Expanding Seniors' Mobility through Phone Apps: Potential Responses from the Private and Public Sectors." Journal of Planning Education and Research, 2018. $0739456 \times 18769133$.

Sion, J., C. Brakewood, and O. Alvarado. "Planning for new fare payment systems: an equity analysis of smartphone, credit card, and potential mobile ticketing adoption by bus riders in Nassau County". Presented at 95th Annual Meeting of the Transportation Research Board, Washington, D.C., 2016. 
Smith, A., K. McGeeney, M. Duggan, L. Rainie, and S. Keeter. "U.S. smartphone use in 2015.". 2015 https://www.pewresearch.org/internet/2015/04/01/us-smartphone-use-in2015/.

Spin. "Spin Access". https://blog.spin.pm/spin-access-49c9a500e949. Accessed 08-202019, 2019.

Transport for London. "Cash free buses". https://tfl.gov.uk/modes/buses/cash-freebuses. Accessed 07-22-2019, 2019.

TriMet "Pay Your Fare With Your Phone." https://myhopcard.com/home/pay-with-yourphone. 2019.

Velaga, N. R., M. Beecroft, J. D. Nelson, D. Corsar, and P. Edwards. "Transport poverty meets the digital divide: accessibility and connectivity in rural communities." Journal of Transport Geography, 2012. 21: 102-112.

Wallischeck, E. Y., T. Weisenberger, A. Berthaume, and M. G. Dinning. "TCRP Report 177: Preliminary Strategic Analysis of Next Generation Fare Payment Systems for Public Transportation". Transit Cooperative Research Program of the Transportation Research Board TCRP Project, Washington, D.C., 2015 https://www.nap.edu/catalog/22158/preliminary-strategic-analysis-of-next-generationfare-payment-systems-for-public-transportation.

Washington Metropolitan Area Transit Authority. 2019. "Metro opens new Andrews Bus Garage, ends cash-free pilot effective with bus service changes June 23", [Press Release], https://www.wmata.com/about/news/June-2019-Bus-Service-Changes.cfm Accessed 07-26-2019.

Washington Metropolitan Area Transit Authority. "Route 79 MetroExtra Goes Cashfree". https://www.wmata.com/service/bus/79-cash-free.cfm. Accessed 07-26-2019, 2019.

Windmiller, S., T. Hennessy, and K. E. Watkins. "Accessibility of Communication Technology and the Rider Experience: Case Study of Saint Louis, Missouri, Metro." Transportation Research Record, 2014. 2415: 118-126. 


\section{APPENDIX 1: FOCUS GROUP DISCUSSION GUIDE}

\section{General transportation Challenges [25 mins]}

General travel

Where do you normally travel?

How do you travel?

Why do you travel?

Time of day of travel

Transit use - Most commonly used bus routes

Biggest challenges - would you travel more if you could? What is your biggest challenge?

\section{New fare technologies overview [10 mins]}

Review automated fare technologies -Mobile ticketing (apps), smart cards, etc.

Review worksheet describing payment options

Requires access to internet (smartphones, computer)

Requires access to banking/credit

\section{Discussion [25 mins]}

Initial impressions

Looking at challenges

Smartphones

Apps - how to use? download, configure?

Languages?

Connect to Credit Card - trust?

Credit cards and bank accounts - have them?

Internet at home, work?

Cell and data plans? Wifi?

Ideas to make the transition better? Training? Low-cost smart phones? Free Wifi? 


\section{APPENDIX 2: INTERCEPT SURVEY INSTRUMENT}

\section{Introduction}

Hello, we are conducting a research study about how new technologies will change how we pay for transit fares, and how that will affect transit riders. I am inviting you to take a brief survey with me - it will take about 5 minutes. If you don't have time now, I can give you a paper copy and pre-paid envelope to mail back in to us. You have the right to skip any question and to stop participation at any time. There are no foreseeable risks from your participation. Your responses will be anonymous - we won't need your name. The information gathered from your participation in this study will be used to inform recommendations on how to improve transit fare payment systems.

Si le gustaría tomar este sondeo en Español, puede cambiar los ajustes de idioma por el botón en la esquina superior derecho.

\section{Information About Your Transit Use}

Q1 How often do you use public transportation (Bus, MAX, Streetcar)?

Never

- Very rarely (a few times a year)

- Rarely (a few times a month)

- Once or twice a week

- Daily

\section{Information About Phone, Data, Internet and Banking Access}

Q2 Cell phones that use the internet and install new applications (apps) are called "smartphones". Is your phone a smartphone?

- Yes, it is a smartphone

- No, it is not a smartphone

- I don't know if my phone is a smartphone

- I don't have a cell phone or smartphone

Q3 How concerned are you about running out of monthly data on your phone?

- Very concerned

- Somewhat concerned

- Not very concerned

- I never need to save data

- N/A - I do not use the internet on my phone

Q4 How do you typically access the internet? (Check all that apply)

- Home internet

- Work internet

- Library 
- Mobile internet/cell phone data plan

- No access to the internet

- Other

Q5 Which of the following do you have access to? (Check all that apply)

- Savings Account

- Checking Account

- Debit Card

- Credit Card

- Prepaid or Gift Card (with Mastercard / Visa logo)

- PayPal, Venmo, Cash App

\section{Comfort in using automated payment systems}

Q6a How comfortable are you in using your credit, debit, prepaid cards or bank account information to purchase transit tickets or regularly load your transit cards (Hop cards):

Using your financial information on the TriMet website one time without allowing the website to store it

- Completely uncomfortable

- Slightly Uncomfortable

- Slightly Comfortable

- Completely comfortable

- Don't know / Not applicable

Storing your financial information in the TriMet website for regular payments

- Completely uncomfortable

- Slightly Uncomfortable

- Slightly Comfortable

- Completely comfortable

- Don't know / Not applicable

Storing your financial information in your smartphone connected to the Hop App for regular payments

- Completely uncomfortable

- Slightly Uncomfortable

- Slightly Comfortable

- Completely comfortable

- Don't know / Not applicable

Giving your financial information over the phone to TriMet

- Completely uncomfortable

- Slightly Uncomfortable

- Slightly Comfortable

- Completely comfortable

- Don't know / Not applicable 
Q6b If you are uncomfortable, what are your major concerns about linking your financial information?

\section{Information About How You Pay for Transit}

Q7 How often do you use the following payment methods to pay for your transit fare?

Employer/School pays for a transit pass

Never, Rarely, Often, Always

Cash on board (only on bus)

Never, Rarely, Often, Always

Cash at a ticket vending machine

Never, Rarely, Often, Always

Cash at TriMet ticketing office or retail store

Never, Rarely, Often, Always

Credit/Debit through Apple/Android Pay on board

Never, Rarely, Often, Always

Credit/Debit at a Ticket Vending Machine

Never, Rarely, Often, Always

Credit/Debit through a smartphone app or computer

Never, Rarely, Often, Always

Credit/Debit at a TriMet ticketing office or retail store

Never, Rarely, Often, Always

Display This Question: (Display Logic for Question 8)

If: How often do you use the following payment methods to pay for your transit fare? = Cash on board (only on bus) [Often or Always]

Q8 Imagine a situation where in the future, cash may not be accepted on board transit. Cash would still be accepted at TriMet Ticket Offices or retail stores like Plaid Pantry, 7 Eleven, Fred Meyers, Safeway, etc. to load onto HOP Cards or to buy paper tickets, as well as at ticket vending machines. If this were the case, how would you primarily pay for your fare?

- Cash at a ticket vending machine (at Max stations)

- Cash at TriMet Office or Retail Store

- Credit/Debit contactless cards or smartphone wallet (Apple/Android Pay) on board

- Credit/Debit at a ticket vending machine 
- Credit/Debit through a smartphone app or computer

- Credit/Debit at TriMet Office or Retail Store

- I would not be able to use the bus or streetcar

Q9 Are you aware there are discounted passes for low-income families and individuals (below $\$ 25,000 /$ year for an individual or $\$ 50,000$ for a family of four)?

- Yes- I'm aware of the Honored Citizen Pass

- Yes - I have applied or have a low-income honored citizen card already

- No

\section{Questions About You and Your Household}

Q10 What year were you born?

Q11 Are you:

- Female

- Male

- Non-Binary / Third Gender

- Prefer to Self-Describe

- Prefer not to say

Q12 Do you experience some sort of mobility related challenge or disability?

- Visual Challenge

- Physical / Motor Challenge

- Cognitive Challenge

- I do not experience a mobility related challenge

Q13 Are you (select all that apply):

- Employed Full Time

- Employed Part Time

- Student

- Homemaker

- Unemployed

- Retired

- Unable to work due to a disability

Q14 What was your approximate annual household income last year?

- Less than $\$ 14,999$

- $\$ 15,000$ to $\$ 24,999$

- $\$ 25,000$ to $\$ 34,999$

- $\$ 35,000$ to $\$ 49,999$

- $\$ 50,000$ to $\$ 74,999$

- $\$ 75,000$ to $\$ 99,999$

- $\$ 100,000$ to $\$ 149,999$ 
- $\$ 150,000$ or more

- Prefer not to say

Q15 Are you Hispanic or Latino (of any race)?

- Yes

- No

Q16 What is your race? (please select all that apply)

- Black or African American

- White / Caucasian

- American Indian or Alaskan

- Asian

- Native Hawaiian or Other Pacific Islander

- Two or More Races

- Prefer to Self-Describe

Q17 What is your home zip code? 


\section{APPENDIX 3: AGENCY PRACTICE SCAN CONTACT LIST}

\begin{tabular}{|c|c|c|}
\hline Agency & Location or Office & Department \\
\hline $\begin{array}{l}\text { Albuquerque Transit } \\
\text { Department }\end{array}$ & Albuquerque, NM & Transit Department \\
\hline $\begin{array}{l}\text { Albuquerque Transit } \\
\text { Department }\end{array}$ & Albuquerque, NM & Transit Department \\
\hline $\begin{array}{l}\text { Charlotte Area Transit } \\
\text { System }\end{array}$ & Charlotte, NC & $\begin{array}{l}\text { Marketing, } \\
\text { Communications \& } \\
\text { Technology }\end{array}$ \\
\hline $\begin{array}{l}\text { Chicago Transit } \\
\text { Authority }\end{array}$ & Chicago, IL & $\begin{array}{l}\text { Revenue and Fare } \\
\text { Systems }\end{array}$ \\
\hline $\begin{array}{l}\text { Chicago Transit } \\
\text { Authority }\end{array}$ & Chicago, IL & $\begin{array}{l}\text { Revenue and Fare } \\
\text { Systems }\end{array}$ \\
\hline $\begin{array}{l}\text { Chicago Transit } \\
\text { Authority }\end{array}$ & Chicago, IL & $\begin{array}{l}\text { Revenue and Fare } \\
\text { Systems }\end{array}$ \\
\hline $\begin{array}{l}\text { City of Santa Fe } \\
\text { Transportation } \\
\text { Department }\end{array}$ & Santa Fe, NM & Transit Department \\
\hline $\begin{array}{l}\text { City of Santa Fe } \\
\text { Transportation } \\
\text { Department }\end{array}$ & Santa Fe, NM & $\begin{array}{l}\text { Transit Department, } \\
\text { Administration }\end{array}$ \\
\hline King County Metro & Seattle, WA & \\
\hline $\begin{array}{l}\text { Lafayette Transit } \\
\text { Agency }\end{array}$ & Lafayette, LA & \\
\hline Los Angeles Metro & Los Angeles, CA & $\begin{array}{l}\text { Office of Extraordinary } \\
\text { Innovation }\end{array}$ \\
\hline Los Angeles Metro & Los Angeles, CA & $\begin{array}{l}\text { Office of Extraordinary } \\
\text { Innovation }\end{array}$ \\
\hline Los Angeles Metro & Los Angeles, CA & Office of the CEO \\
\hline Los Angeles Metro & Los Angeles, CA & \\
\hline $\begin{array}{l}\text { City of Madison Metro } \\
\text { Transit }\end{array}$ & Madison, WI & \\
\hline $\begin{array}{l}\text { Maryland Transit } \\
\text { Administration }\end{array}$ & Baltimore, MD & Senior Executive Team \\
\hline $\begin{array}{l}\text { Maryland Transit } \\
\text { Administration }\end{array}$ & Baltimore, MD & $\begin{array}{l}\text { Office of Equal Opportunity } \\
\text { Compliance Programs }\end{array}$ \\
\hline $\begin{array}{l}\text { Massachusetts Bay } \\
\text { Transportation Authorit }\end{array}$ & Boston, MA & \\
\hline
\end{tabular}


Massachusetts Bay

Transportation Authority Boston, MA

Massachusetts Bay

Transportation Authority Boston, MA

Miami Dade Miami, FL

San Francisco

Municipal

Transportation Agency San Francisco, CA

San Francisco

Municipal

Transportation Agency San Francisco, CA

San Francisco

Municipal

Transportation Agency

San Francisco, CA

San Francisco

Municipal

Transportation Agency San Francisco, CA

Finance and Information

Technology

Finance and Information

Technology

Southeastern

Pennsylvania

Transportation Authority Philadelphia, PA

Southeastern

Pennsylvania

Transportation Authority Philadelphia, PA

Finance and Information

Technology

Southeastern

Pennsylvania

Transportation Authority Philadelphia, PA

Trimet

Portland, Oregon

Washington

Metropolitan Area

Transit Authority

Washington, D.C.

Financial Office

Washington

Metropolitan Area

Transit Authority

Washington, D.C.

Office of Innovation

Washington

Metropolitan Area

Transit Authority

Washington

Metropolitan Area

Transit Authority

Washington, D.C.

Consultant, LTK

Ambler/Philadelphia

New Payment

Technologies/Revenue

Operations

Financial Offce

Fare Payments

Washington, D.C.

Planning Department

Denver, CO 


\begin{tabular}{|c|c|c|}
\hline $\begin{array}{l}\text { Birmingham-Jefferson } \\
\text { County Transit Authority } \\
\text { (BJCTA) }\end{array}$ & Birmingham, AL & $\begin{array}{l}\text { Office of Civil Rights - } \\
\text { Diversity \& Inclusion }\end{array}$ \\
\hline $\begin{array}{l}\text { Montgomery Area } \\
\text { Transit System } \\
\text { (MATS/"The M") }\end{array}$ & Montgomery, AL & $\begin{array}{l}\text { emailed asking for an } \\
\text { appropriate contact }\end{array}$ \\
\hline $\begin{array}{l}\text { Dallas Area Rapid } \\
\text { Transit (DART) }\end{array}$ & Dallas, TX & Executive Team \\
\hline $\begin{array}{l}\text { Dallas Area Rapid } \\
\text { Transit (DART) }\end{array}$ & Dallas, TX & Executive Team \\
\hline $\begin{array}{l}\text { Dallas Area Rapid } \\
\text { Transit (DART) }\end{array}$ & Dallas, TX & IT \\
\hline $\begin{array}{l}\text { Dallas Area Rapid } \\
\text { Transit (DART) }\end{array}$ & Dallas, TX & Diversity Department \\
\hline $\begin{array}{l}\text { Metropolitan Transit } \\
\text { Authority of Harris } \\
\text { County, Texas } \\
\text { (METRO) }\end{array}$ & Houston, TX & $\begin{array}{l}\text { Executive Leadership } \\
\text { Team }\end{array}$ \\
\hline El Paso County Transit & El Paso, TX & $\begin{array}{l}\text { Planning and Development } \\
\text { Department }\end{array}$ \\
\hline $\begin{array}{l}\text { Transit Authority of the } \\
\text { City of Omaha (Metro) }\end{array}$ & Omaha, NE & $\begin{array}{l}\text { emailed asking for an } \\
\text { appropriate contact }\end{array}$ \\
\hline $\begin{array}{l}\text { Valley Metro Regional } \\
\text { Public Transportation } \\
\text { Authority (Valley Metro) }\end{array}$ & Phoenix, AZ & Media Relations \\
\hline $\begin{array}{l}\text { Valley Metro Regional } \\
\text { Public Transportation } \\
\text { Authority (Valley Metro) }\end{array}$ & Phoenix, AZ & Media Relations \\
\hline $\begin{array}{l}\text { Valley Metro Regional } \\
\text { Public Transportation } \\
\text { Authority (Valley Metro) }\end{array}$ & Phoenix, AZ & City of Phoenix \\
\hline $\begin{array}{l}\text { Regional Transportation } \\
\text { Commission of Washoe } \\
\text { County }\end{array}$ & Reno, NV & $\begin{array}{l}\text { Administrative Services } \\
\text { Department }\end{array}$ \\
\hline $\begin{array}{l}\text { Regional Transportation } \\
\text { Commission of } \\
\text { Southern Nevada }\end{array}$ & Las Vegas, NV & \\
\hline $\begin{array}{l}\text { Santa Clara Valley } \\
\text { Transportation Authority }\end{array}$ & San Jose, CA & $\begin{array}{l}\text { BART Silicon Valley } \\
\text { Community Outreach }\end{array}$ \\
\hline $\begin{array}{l}\text { Santa Clara Valley } \\
\text { Transportation Authority }\end{array}$ & San Jose, CA & $\begin{array}{l}\text { BART Silicon Valley } \\
\text { Community Outreach }\end{array}$ \\
\hline Valley Regional Transit & Boise, ID & Community Relations \\
\hline
\end{tabular}




\begin{tabular}{|c|c|c|}
\hline $\begin{array}{l}\text { Gary Public } \\
\text { Tansportation Corp }\end{array}$ & Gary, Indiana & \\
\hline Port Authority & Pittsburgh, PA & \\
\hline $\begin{array}{l}\text { American Bus } \\
\text { Benchmarking Group }\end{array}$ & & Current Group President \\
\hline $\begin{array}{l}\text { American Bus } \\
\text { Benchmarking Group }\end{array}$ & & Current Vice President \\
\hline $\begin{array}{l}\text { American Bus } \\
\text { Benchmarking Group }\end{array}$ & & ABBG Project Manager \\
\hline $\begin{array}{l}\text { Transportation } \\
\text { Research Board }\end{array}$ & & $\begin{array}{l}\text { Senior Program Officer, } \\
\text { Public Transportation }\end{array}$ \\
\hline $\begin{array}{l}\text { Transportation } \\
\text { Research Board }\end{array}$ & $\begin{array}{l}\text { TRCP Project Panel on } \\
\text { Understanding Changes in } \\
\text { Demographics, Preferences, and } \\
\text { Markets for Public } \\
\text { Transportation }\end{array}$ & Senior Program Officer \\
\hline $\begin{array}{l}\text { Transportation } \\
\text { Research Board }\end{array}$ & $\begin{array}{l}\text { Committee on Public } \\
\text { Transportation Marketing and } \\
\text { Fare Policy }\end{array}$ & \\
\hline $\begin{array}{l}\text { Transportation } \\
\text { Research Board }\end{array}$ & $\begin{array}{l}\text { Committee on Emerging and } \\
\text { Innovative Public Transportation } \\
\text { and Technologies }\end{array}$ & \\
\hline $\begin{array}{l}\text { Transportation } \\
\text { Research Board }\end{array}$ & Environmental Justice & Chair \\
\hline APTA & Fare Collection Technology & Coordinator \\
\hline
\end{tabular}




\title{
APPENDIX 4: RESPONSES TO AGENCY PRACTICE SURVEY
}

\author{
1. In what ways has your agency modernized fare payment and technology systems in \\ the past 5 years? Are you transitioning to "cashless" fare payment systems? Over what \\ time frame are any transitions occurring?
}

[AGENCY A:] [XYZ] hasn't upgraded/modernized our fare collection system in the last 5 years. We are currently in the middle of a request for proposals process to select a vendor for a new, region-wide fare collection system that consists of replacing the existing system and going to a mobile application and reloadable smartcards for managing fare purchases and use on bus and light rail. We have a current retail network of 800 stores where fares can be purchased with cash and cash is accepted on the bus and for light rail. Those locations are strategically located to avoid disparate or disproportionate impacts to Title VI populations.

[AGENCY B:] [XYZ] has added a layer onto our legacy [XYZ] transit system that enables external program integration, using a [XYZ] Wallet for payment, program sign-up, shared discounts, rewards and incentives across any number of external multi-modal programs such as Bike Share. [XYZ] launched the first integration with Bike Share in October 2018 and we are currently in negotiations with over 20 additional services/programs that want to join with [XYZ] payment. These include scooter sharing, trikes, electric vehicle car charging, microtransit, parking services and more. We would love to go completely cashless, but state and federal laws are getting more strict on restricting the cash customer and so instead of completely removing cash, we are creating ways for cash customers to participate by using outside programs like PayNearMe. PayNearMe allows you to download a bar code and take it to any CVS or 7-Eleven where you can pay the cashier and the cash will electronically be added into your [XYZ] Wallet. Those funds can then be pushed to your [XYZ] card for transit rides or be used directly to purchase Bike Share (and soon other programs).

[AGENCY C:] In the past 5 years, we have added prepaid options on both account-based mobile ticketing and contactless card platforms. The contactless card, which is our regional [XYZ] system, owned and operated by [XYZ] [XYZ], allows customers to transfer between partner agencies in our system, including on light rail, express bus, and regular fixed route bus service. The [XYZ] card was initiated about five years ago on our system. During that time, cash fares have reduced from over $50 \%$ of all fare types to about $35 \%$. We launched mobile ticketing in 2017 and continue offering it currently, but this accounts for only about $2 \%$ of pass sales and is most popular with tourists and occasional users who don't need to transfer across agencies as the only way to transfer is with a [XYZ] card.

[AGENCY D:] We are transitioning to a smart card/app fare payment system, but not eliminating cash. Over the next few year, we will begin eliminating mag-stripe passes.

[AGENCY E:] We have not, but we are researching the ways to go to a cashless system. We would like to go cashless. 5 years or less.

[AGENCY F:] [XYZ] implemented a mobile ticketing app on April 2, 2018. We're using a company called [XYZ] that allows passengers to purchase single-trip fares, annual passes, monthly passes, and public school tokens through the app. This exists only to supplement cash fares and physical flash-passes, not to replace them. Otherwise, we have no smart fareboxes, chargeable cards, smart card-readers, etc.

[AGENCY G:] We are currently in the process of implementing an electronic fare collection system. We will continue to collect cash on buses, however, we are transitioning all of our pass products onto the electronic system. We are doing a soft launch of our electronic fare system 
in August and will phase out paper passes in January 2020. Prior to this, we did not have any electronic fare collection at all.

[AGENCY H:] [XYZ] has not upgraded its fare system in the past 5 years. We are looking at a mobile ticketing (smart phone) fare payment system as a supplement to, but not as a replacement to our cash system. This will likely take place over the next 6-9 months

\section{How has your agency evaluated the equity implications (perhaps through a Title VI} analysis) of modernized fare payment and technology systems?

[AGENCY A:] As part of the new fare collection system, a fare equity analysis and Title VI analysis will be conducted as part of the new system. Any negative disparate or disproportionate impacts to low income or minority populations identified during the analyses will be mitigated.

[AGENCY B:] We have not eliminated cash, so no Title VI necessary. We are just providing additional means for the unbanked/underbanked to participate.

[AGENCY C:] A Title VI analysis was done by [XYZ] on the [XYZ] system, and we did a Title VI analysis before launching mobile ticketing.

[AGENCY D:] Yes, it was included in an equity analysis.

[AGENCY E:] N/A

[AGENCY F:] [XYZ] has had conversations about the equity implications. Implementing our mobile ticketing through [XYZ] happened pretty quickly, so it was not included in our last Title $\mathrm{VI}$ analysis, and we have just started the process of updating our next Title VI plan, so the subject has not been included yet. Part of the original goal of implementing mobile ticketing was to cut out paper transfers. Currently, we print booklets of paper transfers that we cut for passengers to help them complete their trip, but creating these booklets is costly and just a generally clunky system. The original goal of mobile ticketing was that it would allow passengers to keep their fare on their phones and avoid needing to ask for a transfer, hopefully making them so rarely needed that we could stop producing them. However, [XYZ] decided that the people at the end who were not taking of mobile ticketing were likely doing to be our most vulnerable passengers, so we decided to keep the current transfer options available.

[AGENCY G:] We have conducted a Title VI analysis on the changes we are making. [AGENCY H:] Because we are not eliminating cash fares, we have not studied the equity implications. We do know that approximately $15 \%$ of our fares are paid in cash with one route as high as $20 \%$.

3. What policies, programs, or projects has your agency deployed to mitigate the impacts of automated payment fare systems on customers that live or work in transit deficient areas (e.g. far from ticket vending machines); un- or under-banked customers; customers without readily available internet access; customers who do not own smartphones or have low technological literacy; customers with limited English proficiency; and others potentially excluded from automated payment fare systems?

[AGENCY A:] See answer to question \#2.

[AGENCY B:] See above for the unbanked/underbanked question. [XYZ] is always concerned about equity for our customers. As I said, we have not eliminated cash, but we do see it downtrending. Over $70 \%$ of [XYZ]'s customers own cell phones and the number is growing. 
There are social service programs in [XYZ] County that enable free and low cost cell phones to help the poorer customers and there are free computers available for use in libraries. You can use PayNearMe in the checkout of the [XYZ] Wallet without being a registered customer, so those folks who don't trust banks can still purchase anonymously. Our ticket vending machines are available for cash use and we accept cash for fare and we allow folks to purchase and/or load a [XYZ] card aboard all [XYZ] buses.

[AGENCY C:] For the [XYZ] system, unbanked customers can use Pay Near Me and purchase or top off their cards at local check cashing stores, libraries, and other partners, and Ticket Vending Machines which take cash are broadly available. One does not need to have a credit card or bank account to get or load a [XYZ] card. For mobile ticketing, we surveyed customers and found $80 \%$ of our English-speaking customers and about $75 \%$ of our Spanish-speaking customers had a mobile phone and a data plan. Mobile tickets can be purchased at our store with cash and sent to smart phones for unbanked customers. Since the overall adoption rate of mobile ticketing for us is only $2 \%$, and since the means exists to purchase with cash, there is no Title VI equity issue.

[AGENCY D:] N/A

[AGENCY E:] We have thought about placing tickets vending in public spaces that riders frequent and allow online sales too We also will still have tickets for sale at our offices. We have free Wi-Fi on all the Fixed Route Vehicles.

[AGENCY F:] To protect un- or under-banked customers, we do allow passengers to pay with cash at our [XYZ] facility and load up their mobile ticketing account by paying with cash if they want the convenience of mobile ticketing without being able to connect it to a bank account. To protect customers who do not own smart phones, we have kept all of our non-automated payment systems in place.

[AGENCY G:] Our fare collection system enabled us to leverage a partnership that the vendor of the system [XYZ] has developed with the [XYZ] network. [XYZ] previously had 11 outlets that sold fare media. The new network will allow riders to load value at 74 locations. We are increasing the proportion of residents within $1 / 2$ mile of retail from $10 \%$ now to $50 \%$ under the proposed network. Further, 59\% of low income residents and $54 \%$ of minority residents will have access, so the benefits are actually skewed towards these groups more than other groups.

[AGENCY H:] Again, since we are not eliminating cash fares, we have not done this

\section{What are the costs associated with your agency's equity mitigation strategies?}

[AGENCY A:] Costs of negative mitigation strategies is unknown at this time.

[AGENCY B:] Many agencies have spent half a billion or more to build complex new systems, but [XYZ] has opted to build a hybrid that enables us to keep our legacy system and build a special layer on top that enables modern payment options. Our system costs dimes on the dollar compared to other cities

[AGENCY C:] Although [XYZ] [XYZ] operates the [XYZ] system, we have contributed to funding ticket vending machines (several, at a cost of about $\$ 500 \mathrm{~K}$ each to install plus maintenance costs) in our 58-mile service area. For example, we had a TVM installed at [XYZ] station serviced by our [XYZ] and [XYZ] lines in recent months (although the station is also served by [XYZ] [XYZ] and municipal agencies.)

[AGENCY D:] The initial cost of the distribution network is not broken out separately from the cost of the new fare system. There is a fee associated with every reload at a retailer. 
[AGENCY E:] In the 100's of thousands (we are still researching).

[AGENCY F:] If you consider keeping transfers to be an equity mitigation strategy (even if it is currently kind of a no-action path forward), we spend around $\$ 8,000$ a year to purchase roughly one million transfer slips. Sometimes, we'll place a smaller supplementary to tide us over between years, but that's kind of our baseline.

[AGENCY G:] As I mentioned before, the low income fare program could cost up to $\$ 750,000$ through subsidized passes. We have discussed giving out transit cards (which will cost $\$ 3$ for riders), but do not have any formalized program or idea of how many we would give out. At this time we expect the costs of fare capping to minimal based on how many of our riders have passes (again we work on getting monthly passes to our riders through programs that may have zero cost to the rider). About $86 \%$ of our riders have some sort of pass and the number of riders who ride frequently enough to cap is small. We believe that the benefits for this group are immense, but the actual cost to [XYZ] will be small.

[AGENCY H:] N/A

\section{What else about your riders would you want to know to better understand these issues?}

[AGENCY A:] Current fare collection system is readily accessible to all riders, including the cash-only riders. New fare collection system will address all issues related to unbanked customers.

[AGENCY B:] N/A

[AGENCY C:] We regularly survey our riders and include demographic data as well as finding out their needs and concerns, so I can't think of any further information we would need.

[AGENCY D:] N/A

[AGENCY E:] We are in the process of trying to figure out the exact types of questions to ask: Access to internet; Access to a smart phone; Where would the riders like to see the ticket vending machines; Access to the public libraries to use internet; Does it mitigate that we have free Wi-Fi on the buses?

[AGENCY F:] I believe that there are probably solid options out there that would allow [XYZ] to cut costs and provide better service to our customers, but our outreach program is still pretty nascent and we're still making that effort to learn how to connect with community members. If I could have a broader cross-section of the different groups in our community and how they get information, I think it would be much easier to reach out, touch base, and get the information that we need to start finding an option to increase efficiency without sacrificing equitable operations.

[AGENCY G:] Not sure at this time. Moving to electronic fares is a big change for our agency and we have a lot of questions about how our riders will respond. In regards to things like our low income fare program, we are always curious who is facing barriers accessing these kinds of programs and why. We aren't able to survey for that kind of information. Are there any strategies to help prevent barriers for people who would ride the bus but can't? Our data is usually based on rider surveys, we really don't have a clue about people who aren't currently riding.

[AGENCY H:] Before [XYZ] would embark on a cashless system, we would certainly want to consider all of the issues you have raised here. Additionally, I think we would consult with other transit agencies who have completed this before we would begin our own transition to a cashless system. 
